\title{
Reconstructing Columbus's First Transatlantic Track and Landfall Using Climatological Winds and Currents
}

\author{
by \\ R. A. Goldsmith and P. L. Richardson \\ Woods Hole Oceanographic Institution \\ Woods Hole, Massachusetts 02543

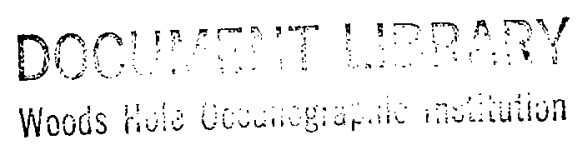

November 1987

\begin{abstract}
Technical Report
Funding was provided in part by the National Science Foundation under grant Number OCE 85-14885.

Reproduction in whole or in part is permitted for any purpose of the United States Government. This report should be cited as:

Woods Hole Oceanog. Inst. Tech. Rept., WHOI-87-46.

Approved for publication; distribution unlimited.
\end{abstract}

Approved for Distribution:

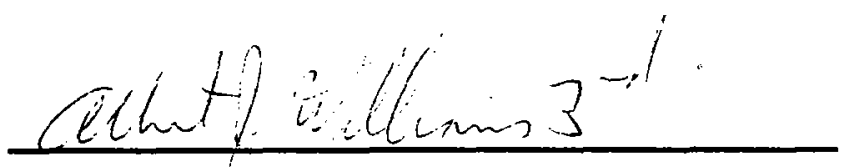

Albert J. Williams, Acting Chairman

Department of Ocean Engineering 


\begin{abstract}
An article in the November 1986 National Geographic magazine examined the question of Columbus's first landfall in the Americas. The author, Luis Marden, was the first to quantitatively include the effects of the winds and currents in reconstructing the transoceanic portion of the voyage. There seemed, however, to be two major weaknesses in his analysis. First, the leeway effect on the ship by the wind was ignored for that portion of the voyage west of $40 \mathrm{~W}$, the whole second half of the voyage. Second, currents from pilot charts were used with the corresponding speed determined by the prevailing current. We sought to reanalyze the track using the leeway effect for the whole transatlantic track and using more appropriate average vector velocities of the current. Using climatological winds and currents we found the island of San Salvador (Watling Island) to be the most likely site of the first landfall of Columbus. This paper discusses the effects of wind, current, leeway, and magnetic variation on the determination of the landfall.
\end{abstract}




\section{Contents}

Abstract .................... i

Table of Contents .................. ii

List of Tables . . . . . . . . . . . . . . . . . iii

List of Figures $\ldots \ldots \ldots \ldots \ldots \ldots$ iv

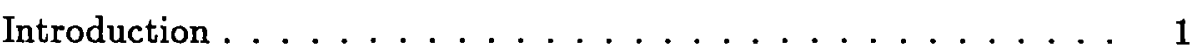

Columbus's $\log$ and course $\ldots \ldots \ldots \ldots \ldots \ldots$

Magnetic corrections . . . . . . . . . . . . . . 4 4

Wind effects .................... 5

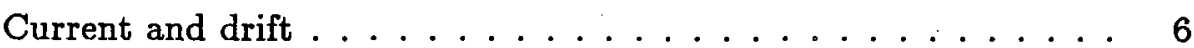

Analysis .......................

Results .................... 8

Conclusions ..................... 12

Acknowledgments . . . . . . . . . . . . . . . 13

Bibliography ...................... 14

Tables ........................ 16

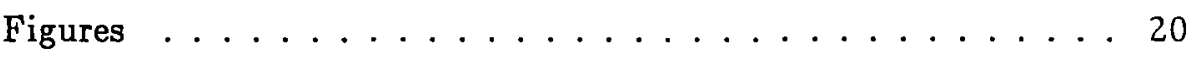

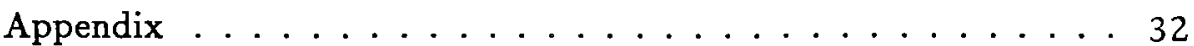




\section{List of Tables}

1 a. Course and distances used in this analysis.

b. Course and distances from the Marden casebook.

2 Summary of scenario track termination points. 


\section{List of Figures}

1 a. Field of magnetic variation, $1500 \mathrm{AD}$.

b. Field of magnetic variation, $1980 \mathrm{AD}$.

2 a. Wind field for September.

b. Wind field for October.

3 a. Current field for September.

b. Current field for October.

4 a. Autumnal current field.

b. Autumnal wind field.

$5 \quad$ Scenario terminations.

6 Parameteric effects of monthly and seasonal fields.

7 Effects of environmental parameters.

8 Effect of varying leeway factor.

$9 \quad$ Western leeway and positioning effect.

10 Best track on environmental fields.

11 a. Field of magnetic variation, $1492 \mathrm{AD}$.

b. Track using $1980 \mathrm{AD}$ field of magnetic variation. 


\section{Introduction}

The publication of articles by Luis Marden and Joseph Judge in the November 1986 National Geographic renewed interest in Columbus's first voyage to the New World. This interest will no doubt heighten in the coming years as 1992 will mark the 500th anniversary of the European rediscovery of the Americas. It is surprising that 500 years after Columbus's first arrival in the Bahamas the precise landfall is still under considerable debate.

Several investigators before Marden have attempted to reconstruct the initial voyage of Columbus to determine the site of the first landfall. For almost 100 years geographers have proposed landfalls ranging from Turk Island in the southeast to Egg Island in the northwest of the Bahama Islands. San Salvador has been favored by researchers such as R.T. Gould, S.E. Morison, and J.W. McElroy. In addition to their recomputation of the transoceanic track, Marden and Judge backtracked from Columbus's description of subsequent landfalls. Their treatment differs from that of previous investigators, such as McElroy [1941], by applying the effects of current and leeway to the course recorded in Columbus's log. Marden's analysis indicates modern day Samana Cay as the probable first landfall. The evidence is not conclusive however. The backtracking analysis is still largely subjective, the extant copies of Columbus's log are ambiguous, and the winds and currents used in the analysis are inappropriate.

Scientists at the Woods Hole Oceanographic Institution (WHOI) have long dealt with the currents and atmospheric conditions which affect the world oceans. Data for current and wind that would affect a sailing voyage like Columbus's are readily available, actively studied, and continually refined. This information could be used to corroborate or refine the work already done, particularily as it applied to the transoceanic portion of his voyage.

This paper will look at the effects of the magnetic variation, atmospheric wind, and ocean currents as the major factors in the determination of Columbus's track. Some of the smaller effects of time and track determination, perhaps overlooked or ignored in previous studies, will also be included. 


\section{Columbus's log and course}

Columbus departed Spain in the late summer of 1492 and proceeded to the Canary Islands. He spent several days there, provisioning his three vessels and waiting for favorable conditions. Leaving Gomera the morning of 06 September (by the Julian calendar) he was almost immediately becalmed, and remained for two days in San Sebastian roads, the straits between Gomera and Tenerife. Then, on the morning of 08 September, the renewal of the northwest tradewinds allowed him to begin his transatlantic voyage. Columbus himself was aboard the Santa Maria, the largest ship of his fleet. The positions recorded in his diary are presumed to be those of his flagship, for the captains of the other vessels, in their search for a landfall, did not always remain within hailing distance of the Santa Maria. The record of the voyage comes from a copy of Columbus's log made by Las Casas; the original log which Columbus kept has long been lost.

At the western end of Columbus's voyage the names associated with the landmarks of his era have become confused. The island of landfall was originally known as Guahanani by the natives who lived there. Which island this is today is the object of investigation. Two prime contenders proposed in previous studies are Watling Island and Atwood Island, also known as San Salvador and Samana Cay respectively. There are, then, still many ambiguities associated with the identification of the first landfall.

Even though the course sailed by Columbus is well known from copies of his log, the resulting track positions are not as equally well understood or agreed on by the many investigators. The first uncertainty is where his actual position was when he started to make headway on the night of 0708 September. Columbus had already been sailing or drifting in very light wind for two days, so the exact position at the start time is not precisely known. The start time was taken as 0300 on the morning of Saturday, 08 September, 1492 [see McElroy, 1941]. The time of 0300 on the morning of 09 September, as stated in the text of the Judge and Marden article seems to be a misprint. To have the voyage starting then is not consistent with the $\log$ entries and leads to unreasonable sailing speeds for the first watch. For the purpose of comparison with previous studies, the start position used in this study was taken from McElroy [1941] as $28.005 \mathrm{~N}, 16.992 \mathrm{~W}$.

The questions surrounding the use of compass headings and the actual distance in a league have not yet been fully resolved. The basic facts regarding the distance and bearing of Columbus's course legs were taken from 
the translation of his diary. The version of the log used [Marden, 1986b] in our analysis is shown in Table 1a. This differs slightly from the course given by Marden, Table $1 b$, in that we have given those portions of days sailed on a different heading, their due weight rather than averaging over the 24 hour day. The compass headings indicate Columbus used a 32 point compass card. This would have divided up the 360 degrees of the compass into bearing points 11.25 degrees apart. If Columbus steered, or reported the heading, to the nearest compass point, a maximum error of $5.625 \mathrm{de}-$ grees in course heading might reasonably be expected. As his heading was usually due west by the compass, the actual error was probably considerably smaller. Apparently Columbus did not attempt to correct for the magnetic variation, certainly not in the western half of the voyage where the variation was not previously known. Until the original diary is discovered, it will have to be assumed that errors in the reported heading are random in nature and their cumulative effects will cancel one another. The distance of the Spanish and Portuguese league was recently rediscovered by Marden [1986] to be 2.819 nautical miles per league; that value was used in this study.

Some discrepancies were encountered in the translation and interpretation of the diary by various investigators. Most notable is the difference in distance sailed on 23 September; McElroy [1941] gives a distance of 22 leagues $(62 \mathrm{~km})$ while Marden [1986b] uses the value of 27 leagues $(76 \mathrm{~km})$. The latter value was used in this analysis, although an attempt was made to preserve the changes in course heading as stated in the log entry for this day.

Two additional factors which do not seem to have been dealt with in previous studies have been included in this analysis. The first is Columbus's method of determining speed. Although the speed of vessels in Columbus's day was usually determined by a log chip, Columbus relied on his own estimate of ship speed. The accuracy of his estimations would depend on his knowledge of the conditions such as sea state and wind as well as that of his vessel and crew. When Columbus was forced to spend a period of time "wearing ship", or changing course, his reckoning of actual headway could only be the result of his computation of the projections of the various legs along his intended path.

Further, the distance and bearing were usually summarized for a whole watch. The "day" watch for this voyage was determined from a period starting about sunrise and ending at sunset. As the vessel track was not far from the earth's equator and occured at the time of the autumnal equinox, 
sunrise was taken to be about 6 am $(0600)$ for this study. The "night" watch likewise began at sunset or about $6 \mathrm{pm}(1800)$, and would continue until the morning of the next day. As all times were local, depending on the sun position, there was a small but significant gain of time as Columbus sailed west. Over the course of the 34 day voyage this amounted to an approximate 0.5 percent increase in the "daily" sailing time. McElroy [1941] thought that Columbus was aware of the noon to noon time being more than 24 hours, but gives no indication of his allowing for it in the computation of distance made good. The analysis presented here will show the effect of this day lengthening in the reconstructed course.

The second factor also relates to time, in this case the season of the voyage. Columbus started to make headway on the morning of 08 September, a date recorded using the convention of the Julian calendar then in effect. The Gregorian calendar system currently in use for most of the world was implemented in 1582 when Pope Gregory decreed that the day following 04 October 1582 should become 15 October 1582 . This was done because the Julian calendar had become out of step with the actual seasons and solstices by ten days. Thus, by the modern calendar, the voyage of Columbus actually occured later in the solar season. Because the voyage took place 90 years before the adoption of the Gregorian calendar, the dates in the diary have been modified by adding nine days. This fact is used in the determination of the correct seasonal factors, such as wind and currents, in the analysis which follows. All summaries will be listed with the Julian dates used by Columbus.

\section{Magnetic corrections}

The effects of the magnetic pole offset from true north must first be considered. When Columbus sailed on a course due west by the compass he was actually traveling west only with respect to the local magnetic field. Further, the magnetic pole was not in the same position in 1492 as it is now. The deviations from true north must be taken into account to determine the actual geographic locations visited by the vessel Santa Maria.

Figure 1a shows a plot of the isogonic lines for magnetic corrections at the approximate time of the Columbus journey. These values were taken from a map published by Van Bemmelen in 1899 and shown by McElroy [1941]. Values for the corrections were taken at five degree increments, then 
interpolated to a one degree grid using a bicubic polynomial algorithm. The values at the original grid nodes were preserved. McElroy used a correction of approximately -1.0 degrees in the region of the Bahamas; grid nodes in that area have been assigned values that are consistent with that interpretation and result in the smooth field shown in Figure 1a. For comparison, Figure $1 \mathrm{~b}$ shows the modern (1980) magnetic corrections. This data set was prepared in the same manner as described above, using values taken from a chart of the North Atlantic Ocean published by the Defense Mapping Agency [1982].

\section{Wind effects}

The wind was the primary force driving Columbus's ships across the Atlantic. Columbus showed the good sense to choose the latitudinal band where the prevailing winds could generally be relied on to blow westward, the direction that he wished to sail. This allowed him to plot a direct course and make the most efficient use of the wind. Nevertheless, the wind was not always directly astern, and thus there would have been a slight slippage due to the force component of the wind acting normal, or perpendicular, to the course steered. This leeway affects every vessel, pushing it sideways through the water.

To determine the leeway requires a measure of both the wind velocity and its effect on a caravel sailing vessel of the type Columbus used on his voyage. The first portion of the track which Columbus followed, in the eastern Atlantic, is marked by the northeast trade winds. These winds are quite consistent in their direction and speed, although there are slight seasonal variations. A study at WHOI on the climate of the North Atlantic [Bunker and Goldsmith, 1979; Goldsmith and Bunker, 1979] used several million ship of opportunity meteorological observations from the period 1948 to 1972 to compute monthly climatological averages for many parameters, including the wind field. These data were further processed to generate monthly averages for the resultant winds at points centered in one degree squares [Isemer and Hasse, 1985]. The component wind fields in the region of the Columbus track were then processed using a bi-linear interpolation algorithm to reconstruct the grid on nodes every one degree. The speed was reconstructed from the vector components to produce an average wind field such as may be encountered by a vessel sailing in that region. This 
procedure was performed for both the September and October data set; the resultant wind fields used in the study are shown in Figure 2. Also generated was a combined vector average of these two months, producing an autumnal wind field (Figure 4b).

The computation of a vessel's leeway is a function of the wind velocity and vessel's course, but also depends on ship design and other parameters. For this analysis the leeway was estimated and taken to be a constant 1.4 percent of the wind component normal to the ship course. This was in close agreement with the 1.5 degree leeway used by Marden [1986] in the region of the northeast tradewinds.

\section{Current and drift}

By measuring the difference between the course and the actual track made good by modern vessels, the ocean current can be measured. A large number of these observations for the years 1875 to 1976 was obtained from the Naval Oceanographic Office and analyzed to produce mean climatological current fields for the twelve months of the year. These data were vector averaged over areas 2 degrees in latitude by 5 degrees in longitude to ensure sufficient observations to provide a reliable estimate of the climatological current field in the open ocean. These monthly data sets were processed using a bilinear interpolation method to produce surface current velocities (direction and speeds) for one degree squares in the region of Columbus's track.

In the region of the Bahama Islands the currents are not nearly so uniform as in the mid Atlantic. The currents vary in both speed and direction among the many islands. Furthermore, the Gulf Stream, which passes between the Bahamas and Florida, has speeds an order of magnitude greater than those encountered in the mid Atalantic. There are also many more drift observations available in this area as it contains frequently traveled shipping lanes. Data in the western area bounded by $.20 \mathrm{~N}, 30 \mathrm{~N}, 70 \mathrm{~W}$, and $80 \mathrm{~W}$ were vector averaged by one degree squares. The resultant field was then used in the region of the Bahamas to negate any influence the Gulf Stream may have contributed in using the larger $2 \times 5$ degree averages (Figure 3 ).

The use of average currents in this analysis differs from the prevailing current speeds taken from monthly pilot charts by Marden. For those charts, the average speed appears to have been computed independently of the direction, or using only a defined primary directional subset of the total 
observations available. While the currents in this region are fairly constant, vector averages over variations in the direction result in a reduced net speed over long climatological time averages. The resultant current speeds were generally found to be approximately a third of those shown in the pilot charts.

The current field used in the analysis of the Columbus voyage are shown in Figure 03. As with the wind field analysis, the monthly data sets were combined to produce an autumnal current field, shown in Figure 4a. The current field indicates that the general circulation of the Atlantic gyre was acting to carry Columbus's vessels westward, with only modest southward and northward deflections occurring at the beginning and end of the voyage respectively.

\section{Analysis}

In recreating the track followed by Columbus, the starting point was taken at $28.005 \mathrm{~N}, 16.992 \mathrm{~W}$ as determined and used by McElroy [1941]. Because the diary generally gives the heading and distance sailed for the 24 hour day or watch, these values had to be taken as a constant for the period being studied. First the heading was corrected to true geographical heading by applying the magnetic compass correction. Using this heading, and the estimate of the distance made good from the log, the velocity of the vessel was calculated.

The position of the vessel is presumed to be known at the start of the time interval and a bilinear interpolation was used to determine the wind speed and direction. When monthly average wind component fields were being used the correct Gregorian date was used to determine the corresponding September or October data set. From the computed wind the component normal to the vessel's course was determined. Multiplying this value by the leeway correction factor produced a velocity of the leeway and this was added to the vessel velocity.

In a similar manner the current velocity was determined for the ship position and added to the vector summation to obtain the vessel velocity. The distance sailed was determined by multiplying the velocity by the time sailed (over the computation interval). When the effects of the progression of local noon were being included, the time interval was multiplied by the factor 1.0046625 . 
Columbus used "dead reckoning" to navigate his fleet; he combined the ship's compass heading, speed, and time of run to determine his "distance made good". This may have been done as often as every one-half hour, that being the standard sand glass interval. In our analysis, his navigation was duplicated as closely as possible by recomputing a new position every one-half hour during the log interval. This reduced some of those effects which may have been introduced by the large, 24 hour time intervals in the log. The smaller time increments give a better realization of the wind and current changes implicit in the one degree squares of environmental and magnetic variation data.

The method used to compute the track positions attempts to duplicate the "rhumb line" navigation as much as possible. This was done by computing the local latitude change and then computing the corresponding change of longitude. A great circle track, as would be obtained using spherical trigonometry, changes significantly as a function of the computational time step. With a small computational time step (one half hour) a great circle track approaches the "rhumb line sailing" method in the determination of a final position for the time step. This would correspond to a helmsman continually adjusting the steering to maintain a constant heading. In reconstructing the track however, it is worth noting that if one uses the spherical trigonometry method and Columbus's log with 24 hour computation intervals, the track termination point is artificially deflected almost 0.4 degrees $(44 \mathrm{~km})$ southward from that obtained by using the rhumb line positioning. For the course in general, great circle solutions are positioned south of those positions produced by the rhumb line analysis used in this study. This point is very important to the analysis procedure. Columbus did not sail a great circle route, the shortest distance to the new world, in part because he did not know the actual position of his final destination.

\section{Results}

Several scenarios were run with this model, applying succesive corrections to account for each of the parameters discussed above. A general overview of the results is shown in Figure 5 and all cases are summarized in Table 2. Also included, for comparison, are the track terminations computed by McElroy [1941], and Marden [1986].

Case 1a presents the track of the course as obtained from the log. No cor- 
rections have been made for magnetic variation, current, or wind. The track does not approach any land and the endpoint is well north of the general area of the Bahamas where a landfall is supposed to have occurred. Correcting for the magnetic variation that was in effect at the time of Columbus's voyage (case $1 \mathrm{~b}$ ) moves the termination of the track south southeast 310 kilometers. This is well short of any land but in the general latitude of the Bahamas and midway between two of the potential landing sites, Watling Island (San Salvador) and Samana Cay.

Adding in the effects of the currents displaces the endpoint westward about 135 kilometers, consistent with the clockwise circulation in the southern portion of the mid-Atlantic gyre. The current field used in this case was the average of the September and October fields and is referred to as "autumnal." The endpoint of the track is now in the longitudinal vicinity of the Outer Bahamas; the track terminates only 32 kilometers southeast of Watling Island. When the leeway effect of the wind is incorporated into the model, the endpoint is moved 8 kilometers northwest so that the final track termination is only about 25 kilometers southeast of Watling Island.

While none of these scenarios proves conclusively a specific landfall, they all favor a more northerly site, close to that of Watling Island. An additional point worth noting is that the last watch of the voyage has a definite northward component to the track. Columbus's last course was 270 degrees (west), but all the major elements, magnetic variation, currents, and winds, conspired to push his vessels northward during this final phase of the voyage. The magnitude and interactions of the various factors are further examined in the following figures.

Also shown in Figure 5 is the effect of the progression of local noon (case 1e). This has been shown applied to the uncorrected track (case 1a), but has also been computed for the fully corrected track and is included in the appendix as case If. The extra sailing time gained in the 24.00466 hour day results in an additional distance sailed, shifting the termination point approximately $25 \mathrm{~km}$ westward. The effect is small but not insignificant considering the distances between the islands on which Columbus might have landed. While the correction for the lengthened day is not used in the majority of the remaining scenarios the magnitude of the effect should be kept in mind.

Figure 6 shows the track endpoints using different combinations of the wind and current fields. The most remarkable feature in these scenarios is 
the small variation in position. All cases result in a termination point in a region roughly $20 \mathrm{~km}$ by $30 \mathrm{~km}$ in extent, centered approximately $35 \mathrm{~km}$ southeast of Watling Island. The tracks reflect a little stronger wind circulation in September, resulting in more northerly velocities in the western Atlantic. The October wind field tends to be more zonal and weaker than in September. The current field reflects a similar pattern. All tracks favor a more northern site for the landfall at Watling Island.

Figure 7 shows the relative contribution of leeway and current. The effect of the current is predominantly longitudinal, reflecting the velocities of the southern portion of the Atlantic gyre. The leeway effect of the winds is shown to be small in comparison. Figure 8 shows the effect of varying the leeway factor. Increasing the leeway factor results in a greater slippage in a direction normal to the course. As the leeway factor was increased, the termination points were moved to the northwest. The effect of using different factors is not as large as that obtained from using the various wind fields shown in Figure 6. Figure 8 also illustrates the influence of the southeast trade winds in the western half of the Atlantic. These would set a vessel northward and offers good proof that Marden should not have assumed following winds (and no leeway) west of $40 \mathrm{~W}$.

Figure 9 shows the progressive effects of removing leeway, using a larger computation interval, and using great circle positioning. The effect of removing the leeway west of $40 \mathrm{~W}$ results in a displacement of the termination points (from case 1d) $22 \mathrm{~km}$ to the southeast. Using a computation cycle equal to the time interval between $\log$ entries results in another small displacement of $9 \mathrm{~km}$ in the same direction (case $5 \mathrm{c}$ ). As discussed earlier, this larger computation interval gives only coarse corrections for winds, currents, and magnetic variation. Finally, the track was computed using spherical trigonometry for great circle positioning (case $5 \mathrm{~d}$ ). The displacement $35 \mathrm{~km}$ to the south demonstrates the positioning errors which may accumulate, especially when using the large computation interval. The net effect of these scenarios displaces the track.termination over $60 \mathrm{~km}$ to the south and could lead to the conclusion that Samana Cay is the landfall.

The uncertainties in the log courses can also have a significant effect on the termination point. Using the course from the casebook [Marden, 1986b] with our autumnal winds and currents and one half hour rhumb line positioning, we saw the voyage terminate $3 \mathrm{~km}$ east of the sourthern tip of Watling Island (case 5e). 
Figure 10 shows the track from case $1 \mathrm{~d}$ (used as the base for the variations discussed in the above figures) superimposed on the environmental fields. The most dominant of the three major factors is the magnetic variation. We used Van Bemmelen's (1899) map for compatibility with the Marden and McElroy studies. As that map is a key component of several Columbus voyage reconstructions, it deserves a closer examination. Van Bemmelen refers to a map by Gelcich (1885), and Gelcich cites Schott (1881). All three of these authors used Columbus's own observations of magnetic variation, made on his first transatlantic voyage. Columbus, or at least the extant copies of his $\log$, provides observations relevant to the magnetic variation on only three occasions - the 13th, 17th, and 30th of September. On 13 September he logged [Morison, 1963] "This day at the beginning of night the compass needles varied to the $\mathrm{NW}$, and in the morning a little to the NE." For 17 September the log read "The pilots took the North in order to mark it, and found that the compass needles varied to the NW a full point; and the mariner's took fright and were troubled and did not say why. The Admiral knew it, and ordered that the North be marked again at dawn, and they found that the needles were true. The reason was that the star appeared to move and not the needles." On 30 September he logged "Also at nightfall the compass needles varied to the $\mathrm{NW}$ one point and at dawn they were right on the Star, whence it appears that the Star moves like the other stars, and the needles always point true."

Thus on both 17 and 30 September the compass read at dusk one point (11.25 degrees) westerly variation and at dawn no variation. The difference in readings in the evening and morning is due to the apparent daily rotation of the North Star which, in the year 1492, was at an angular distance of about 3.5 degrees from true north. The best estimate of magnetic variation for those dates is an average of the evening and morning observations, about 5.6 degrees westerly deflection. An estimate for 13 September is more difficult to pin down because the actual variation at dusk or dawn is not explicitly stated. However, the implied average variation was nearly zero. The variation for the 1492 landfall in the Bahamas also remains uncertain; Schott (1881) concludes "the delination was very small and probably less than $1 / 4$ point west."

Using these direct observations by Columbus, plus Van Bemmelen's value of 3.0E for the Canary Islands and Schotts estimate of 0.0 for the Bahamas, we reconstructed the field of magnetic variation along the track of the Santa Maria (Figure 11a). The geographic position of the vessel at the time of 
the observation was based on the results obtained in our case $6 \mathrm{~d}$. A field of magnetic variation was computed using an algorithm which minimizes the curvature of the fitted surface. The resulting field was similar to that obtained by Van Bemmelen, but our maximum westerly variation is smaller than Van Bemmelen's and shifted to the east. The landfall scenario using this field is shifted to the north and lies right on Watling Island (case 6a).

Although the five values we used reveal the large scale distribution of the variation, no observation was made in the mid Atlantic near where the maximum westerly variation might have been located. In addition, the shape of the field in the region of the Bahamas seems to be mostly conjecture and Columbus's observations of the variation are probably accurate to no better that a few degrees. We think that the average magnetic field of 1492 along the track is known to no better than a degree or two, and thus our identification of a landfall must be tempered with caution.

An interesting sidelight of the effect of the magnetic variation is shown in Figure 11b. This scenario (case $6 \mathrm{~b}$ ) shows approximately what would happen if one tried to laboriously follow Columbus's logged courses and distances with the present magnetic field (1980). The currents and winds have been ignored since if the voyage had gone in this direction the winds and hence the vessel speeds would not have been the same as actually encountered. The resulting track, when compared to cases $1 \mathrm{a}$ and $1 \mathrm{~b}$. (3a) shows how much the magnetic variation influences the termination. A landfall would have been made far to the south, near present day Antigua and Guadaloupe Islands, and would have occurred on 07 October or earlier if the generally westward currents were included in the simulation.

\section{Conclusions}

The results from this analysis give strong evidence that, when historical climatological data are used to correct the course of Columbus's voyage of discovery, the track terminates very closely to a landfall at Watling Island (San Salvador). Using vector averages for the wind and current fields is the more correct approach for reconstructing a one month voyage such as Columbus undertook. While the average speed for the current and wind may be appropriate for a short period such as a day, the speeds resulting from vector averaging give a better model of the mean field likely to be encountered over the longer periods of the voyage. It may be argued that 
Columbus did not have "average" conditions, that the weather may have been anomalous. While the diary gives no record of the unusual, the very fact that the vector averaging accounts for the unusual makes it appropriate.

More importantly, use of the mean vector fields for currents and winds solves the overshoot problem encountered in previous investigations of Columbus's first landfall. Because the assumed currents based on speed alone pushed the supposed landfall far to the west, investigators have had to incorporate some type of "correction" factor, successively shortening the track until a landfall in the proper region was encountered. Use of the 2.819 nautical mile per league conversion factor and the vector averaged fields resulted in all scenario tracks terminating in the eastern edge of the Bahamas near $74 \mathrm{~W}$ longitude.

Questions remain which could affect the results computed here. Where was the actual starting position? What were the precise headings? How accurate is our understanding of the actual 1492 magnetic variation? What was the bearing of the land when first sighted? Did the captain immediately cast anchor, or did they perhaps sail two leagues before anchoring at 2 am on the morning of 12 October? Perhaps the original diary will have to be found to answer these questions. What about the post landfall voyages? The analysis presented here considers only the transoceanic portion of the voyage. The case which Marden presents for subsequent points of contact and cross referencing are persuasive and should be carefully weighed. Finally, to verify the analysis, the methodology presented here might be extended to cover Columbus's voyage back to Spain, or subsequent crossings.

\section{Acknowledgments}

We would like to thank Terry McKee for many editorial suggestions and for her work in processing the ship drift data from the Naval Oceanographic Office. Also, thanks to Deborah Marenna for typing the manuscript. Colleen Hurter located and copied many of the old works on magnetic variation and Walter Zenk help translate the German text in those documents. Jim Price offered several helpful suggestions. Support for part of this work was by National Science Foundation Grant OCE 85-14885. 


\section{Bibliography}

American Practical Navigator, 1984. Defense Mapping Agency $\mathrm{Hy}-$ drographic/Topographic Center, 2 volumes.

Alvar, M. (editor), 1976. Cristobal Colon Dario del Descubrimiento. Island Council of Grand Canary.

Bunker, A. F., and R. A. Goldsmith, 1979. Archive time-series of Atlantic Ocean meteorological variables and surface fluxes. Woods Hole Oceanographic Institution Technical Report WHOI-79-3, Woods Hole, MA.

Defense Mapping Agency, North Atlantic Ocean (INT 12, DMA stock No. WOAGN12), 1982.

Fox, G. V., 1882. Methods and results. Reprinted from the report of the Superintendent of the U.S. Coast and Geodetic Survey for the year ending June 1880, Appendix no 18, 347-411, Washington.

Gelcich, E., 1885. Beitrage zur Geschichte des Zeitalters der Entdeckungen. Zeitschr. der Gesellschaft fur Erdkunde zu Berlin, 20, pp. 280-325.

Goldsmith, R. A., and A. F. Bunker, 1979. Woods Hole Oceanographic Institution Collection of Climatological and Air/Sea Interaction Data, Woods Hole Oceanographic Institution Technical Report WHOI-7970, Woods Hole, MA.

Gould, R. T., 1927. The landfall of Columbus: an old problem restated. Geographical Journal, 69, pp. 403-429.

Isemer, H.-J., and L. Hasse, "The Bunker Climate Atlas of the North Atlantic Ocean - Volume 1: Observations", Springer-Verlag, Heidelberg, 1985.

Judge, J., 1986. Where Columbus found the New World. National Geographic, 170, pp 567-599.

Las Casas, Bartolome de, 1975. Historia de las Inias. Madrid.

Marden, L., 1986. The first landfall of Columbus. National Geographic, 170, pp. 572-577. 
Marden, L., 1986b. "A Columbus Casebook," a supplement to "Where Columbus Found the New World". National Geographic, pp. 48-50.

Morison, S. E., 1974. The European Discovery of America: The Southern voyages. New York, Oxford Press.

Morison, S. E., Admiral of the Ocen Sea, a Life of Christopher Columbus. In 2 volumes. Boston.

Morison, S. E. (editor), 1963. Journals and other documents on the life and voyages of Christopher Columbus. Translated and edited by S. E. Morison. New York, The Heritage Press.

Schott, C.A., 1881. An inquiry into the variation of the compass off the Bahama Islands, at the time of the landfall of Columbus in 1492. Report of the Superintendent of the U.S. Coast and Geodetic Survey for the year 1880. Appendix No. 19, 412-417, Washington.

Van Bemmelen, W., 1899. Die abweichung der magnetnadel. In Supplement to Observations of the Royal Magnetical and Meteorological Observatory at Batavia, 21. Batavia. 
Tables 
Table 01a:

Course of Columbus used in study, based on Diary (see Marden, 1986) Starting position: 28.005N 16.992W (soe McElroy, 1941) Storting time: 08 Sep $0300 \mathrm{~h}$

Watch ending
Date Time

\begin{tabular}{l} 
Date \\
\hline 99 Sep \\
10 Sep \\
11 Sep \\
12 Sep
\end{tabular}

13 Sep

14 Sep

15 Sep

16 Sep

17 Sep

18 Sep

19 Sep

20 Sep

20 Sep

21 Sep

22 Sep

23 Sep

23 Sep

$24 \mathrm{Sep}$

24 Sep

25 Sep

25 Sep

26 Sep

26 Sep

27 Sep

28 Sep

$29 \mathrm{Sep}$

$30 \mathrm{Sep}$

01 Oct

02 Oct

03 Oct

04 Oct

05 Oct

06 Oct

07 Oct

07 Oct

08 Oct

09 Oct

O9 Oct

16 Oct

11 Oct

11 Oct

12 Oct
Composs Bearing

Leagues
Sailed

270.0

270.0

270.0

270.0

270.0

270.0

270.0

270.0

270.0

270.0

270.0

270.0

281.2

292.5

270.0

292.5

315.0

326.2

270.0

270.0

270.0

225.0

270.0

225.0

270.0

270.0

270.0

270.0

270.0

270.0

270.0

270.0

270.0

270.0

270.0

247.5

247.5

225.0

281.2

247.5

247.5

270.0
Noutical
mi les

$\frac{\text { miles }}{25.37}$

126.86

169.14

112.76

93.03

93.03

56.38

76.11

109.94

140.95

155.04

70.47

10.71

10.71

36.65

84.57

38.06

22.83

15.22

40.88

12.69

47.92

32.70

54.69

67.66

39.47

67.66

39.47

70.47

109.94

132.49

177.60

160.68

112.76

64.84

14.10

33.26

14.10

43.69

166.32

76.11

63.43
Kilo- Speed

meters knots

$47.0 \quad 0.94$

$234.9 \cdot 5.29$

313.27 .05

$208.8 \quad 4.70$

$172.3 \quad 3.88$

$172.3 \quad 3.88$

$104.4 \quad 2.35$

$141.0 \quad 3.17$

203.64 .58

$261.0 \quad 5.87$

$287.1 \quad 6.46$

$130.5 \quad 2.94$

$19.8 \quad 0.89$

$\begin{array}{ll}19.8 & 0.89\end{array}$

$67.9 \quad 1.53$

156.63 .52

$70.5 \quad 3.17$

$42.3 \quad 3.26$

$28.2 \quad 3.04$

$\begin{array}{ll}75.7 & 1.70\end{array}$

23.51 .06

$88.8 \quad 3.99$

60.63 .63

$101.3 \quad 3.65$

$125.3 \quad 2.82$

$73.1 \quad 1.64$

$125.3 \quad 2.82$

$73.1 \quad 1.64$

$130.5 \quad 2.94$

203.64 .58

245.45 .52

328.97 .40

$297.6 \quad 6.70$

$208.8 \quad 4.70$

120.15 .89

$26.1 \quad 1.08$

$61.6 \quad 1.39$

$26.1 \quad 2.35$

$80.9 \quad 2.43$

$308.0 \quad 6.93$

141.06 .34

117.57 .93

Notes: The converion factor 2.819 nautical miles per league was used throughout. 
Table 01b:

Plotted course of Columbus as taken from Diary (See Marden 1986) Starting position: $28.000 \mathrm{~N}$ 17.000W Starting time: 08 Sep $0300 h$

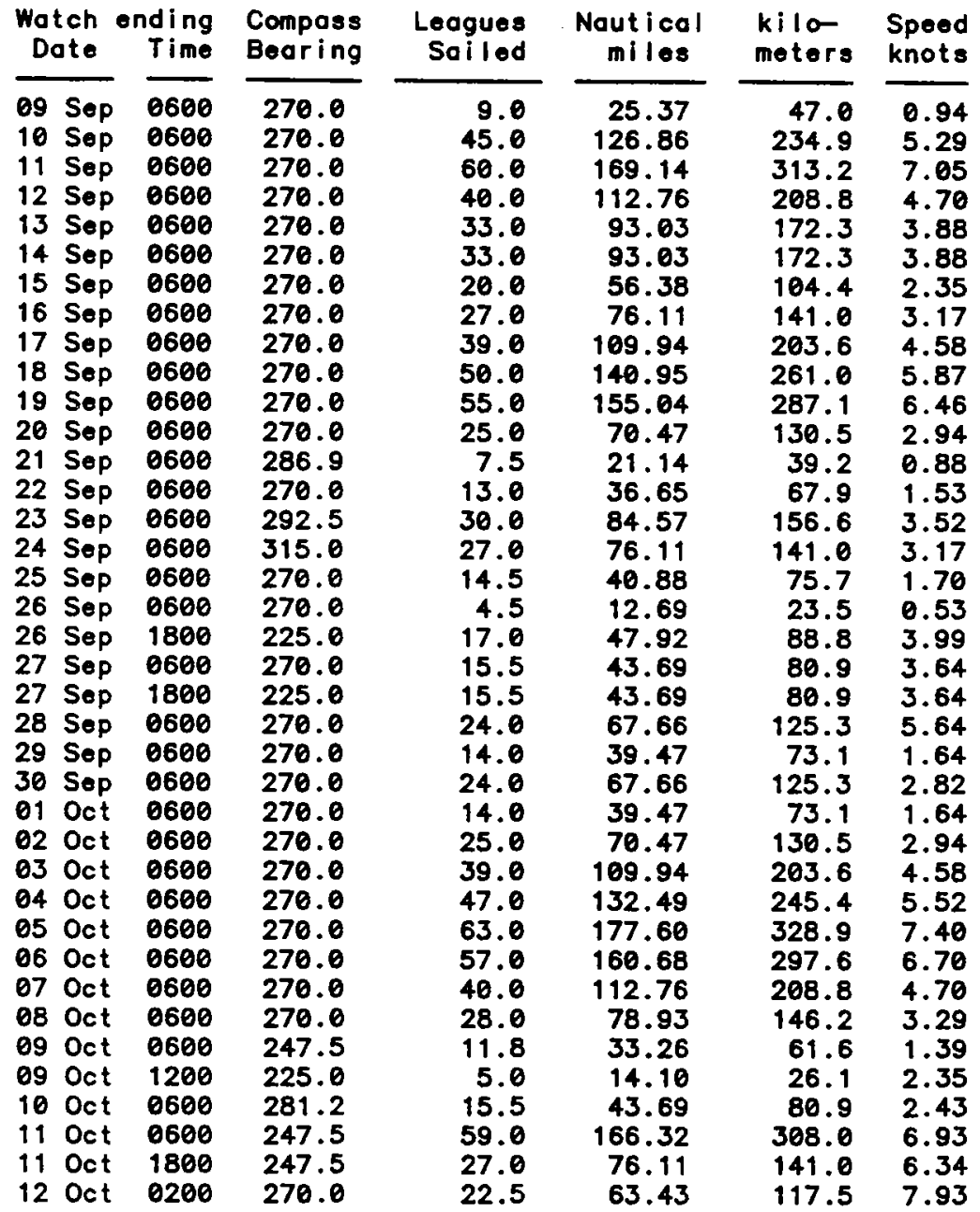

Notes: The conversion factor 2.819 nautical miles per league was use throughout. 
Table 02: Summory of Track Parameters and Termination

Positions for oll Cases

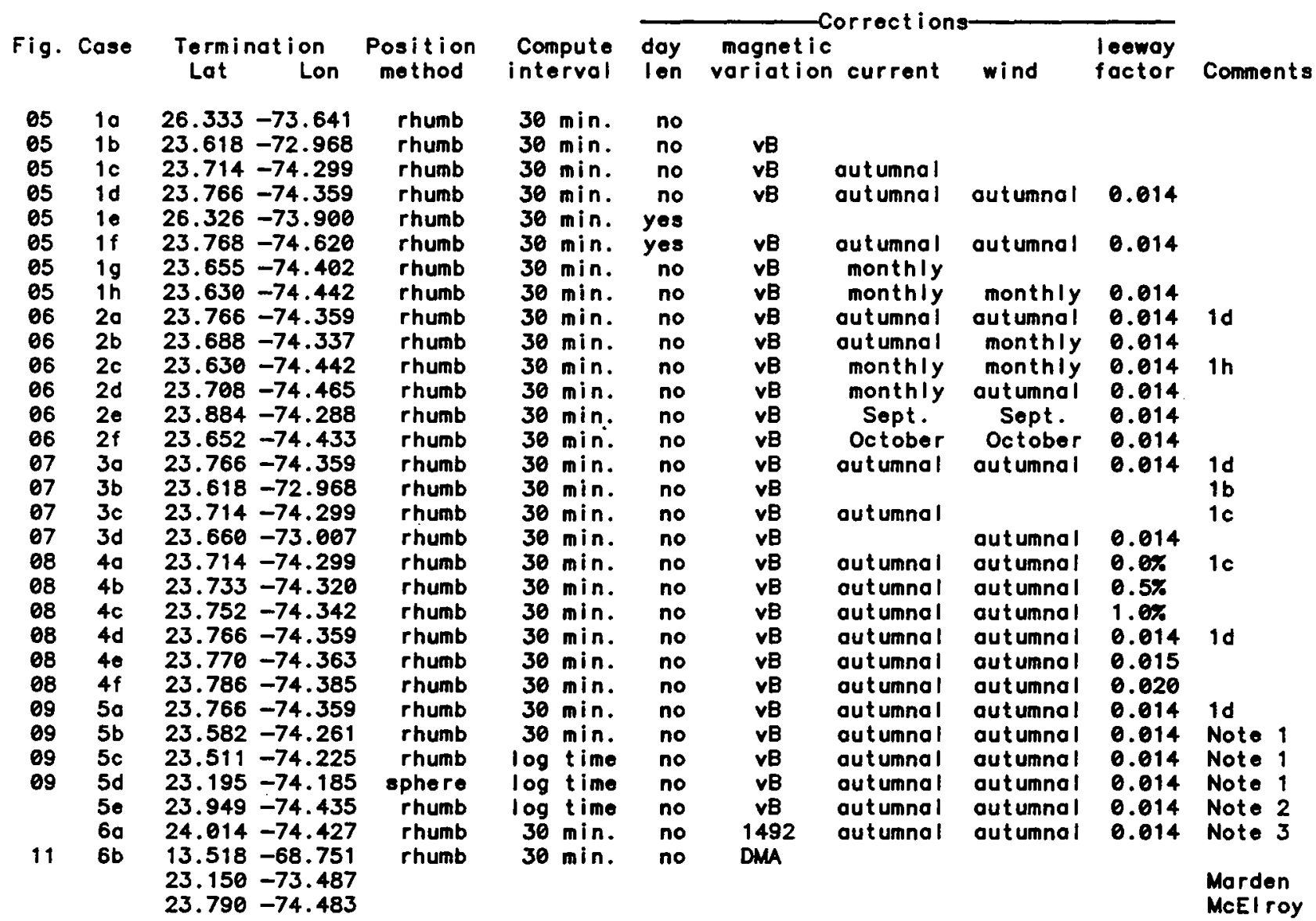

Note 1: Leeway set to 0.0 west of $40 \mathrm{~W}$ to match Marden (1986).

Note 2: Course taken from Casebook. Table 01b (Marden, 1986b)

linear interpolation.

Note 3: Mognetic variation recontructed from Columbus's log by a spotial field of minimum curvature.

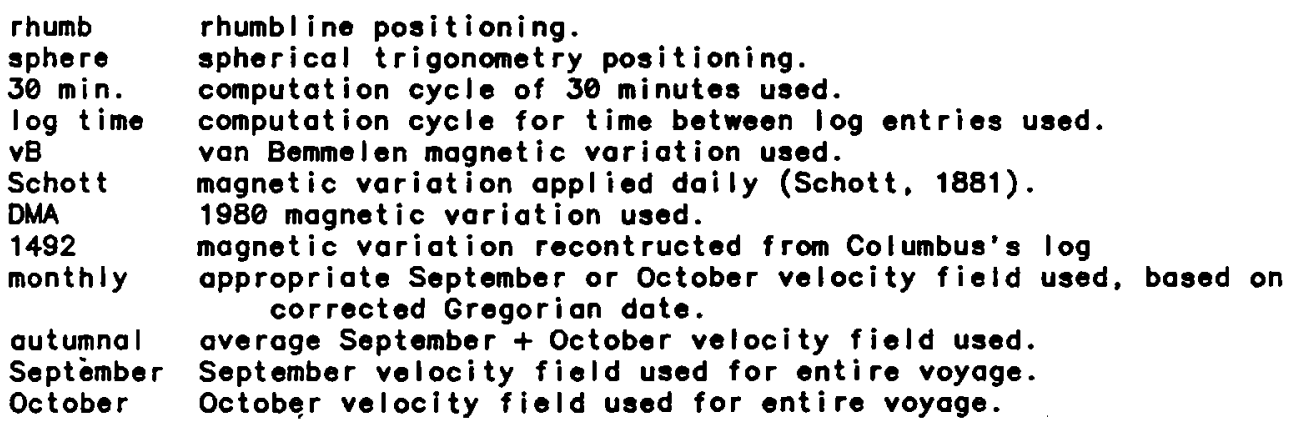


Figures 
1a) Magnetic variation for year 1500 ad.

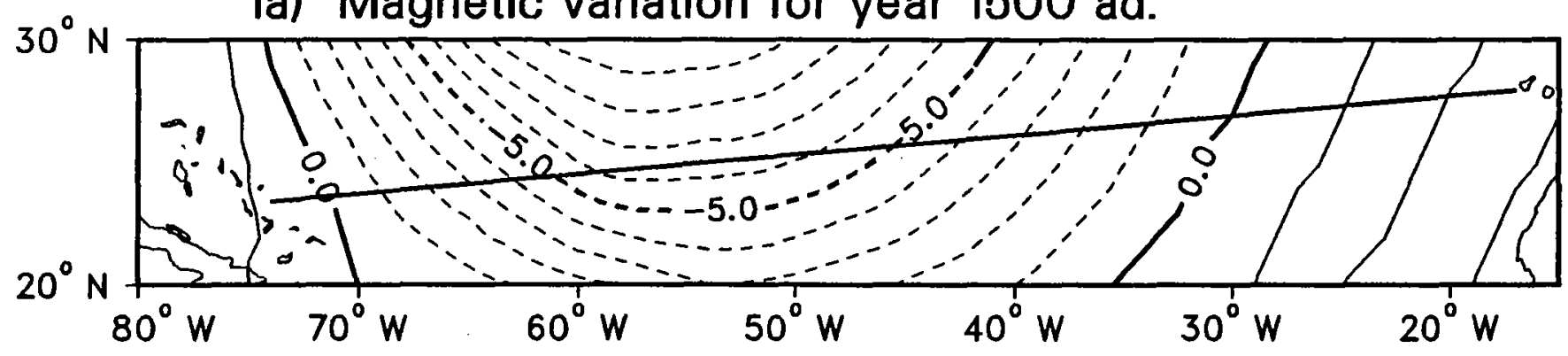

1b) Magnetic variation for year 1980 ad.

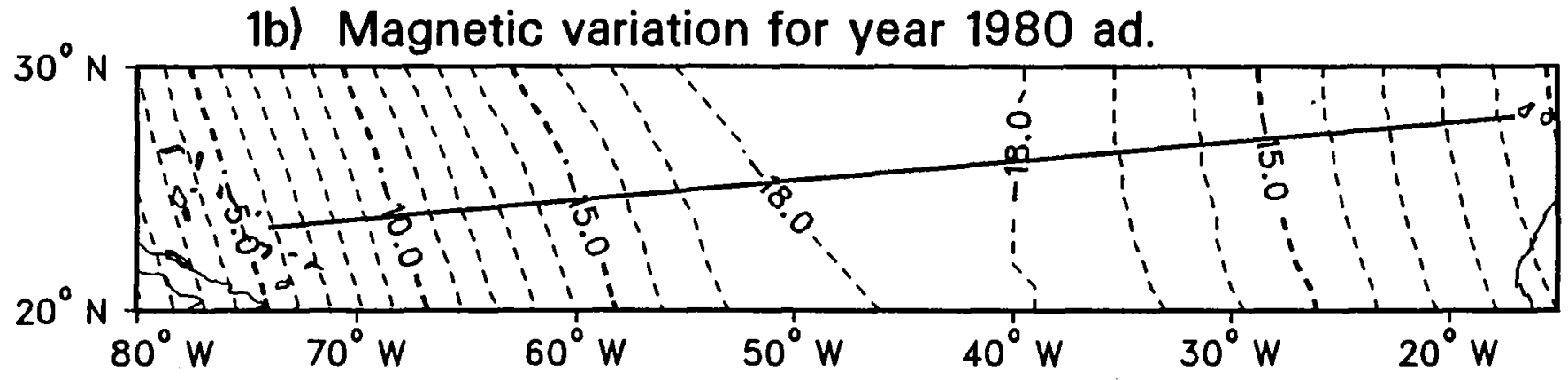

Track made good between voyage start and end positions is shown.

Dashed lines indicate westward deflections and are applied as negative corrections to the compass bearing to obtain true bearing. (Mercator projection).

Figure 1a: Magnetic variation, in degrees from true north, for the year 1500 , from van Bemmelen (1899) as mapped by McElroy (1941).

Figure 1b: Modern (1980) isogonic lines, from Defense Mapping Agency chart WOAGN12. 


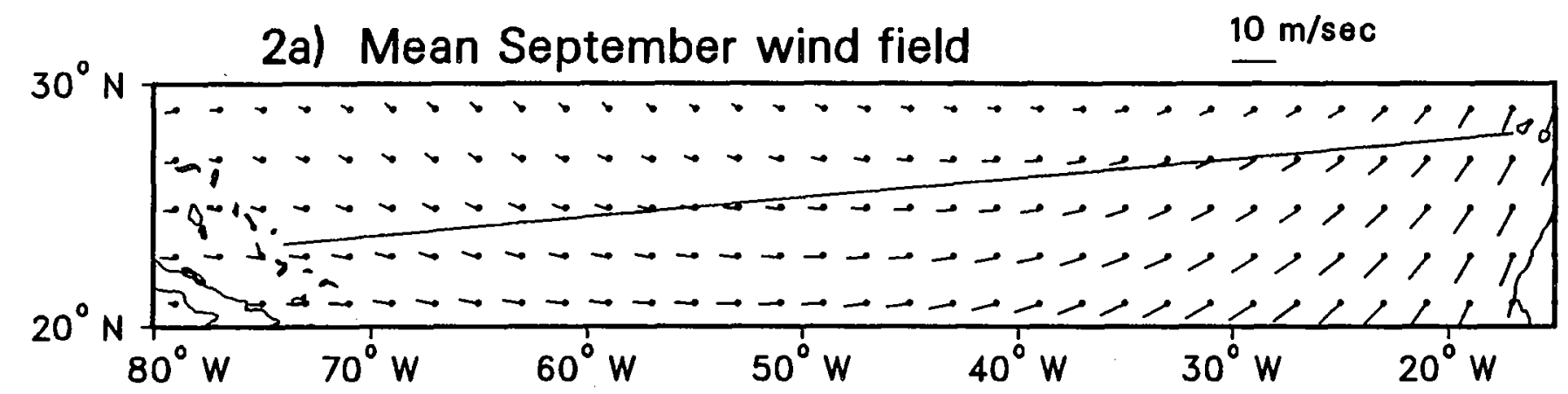

$\approx$

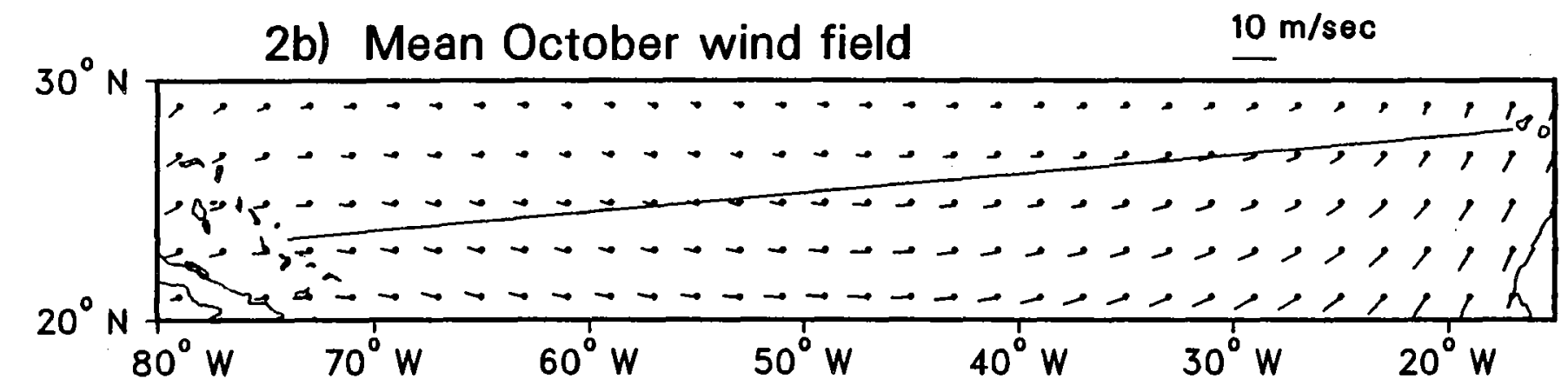

Monthly mean wind fields shown at 2 degree subsample. (Mercator projection).

Figure 2a: Mean wind field for September, from Isemer/Hasse (1985).

Figure 2b: Mean wind field for October. 


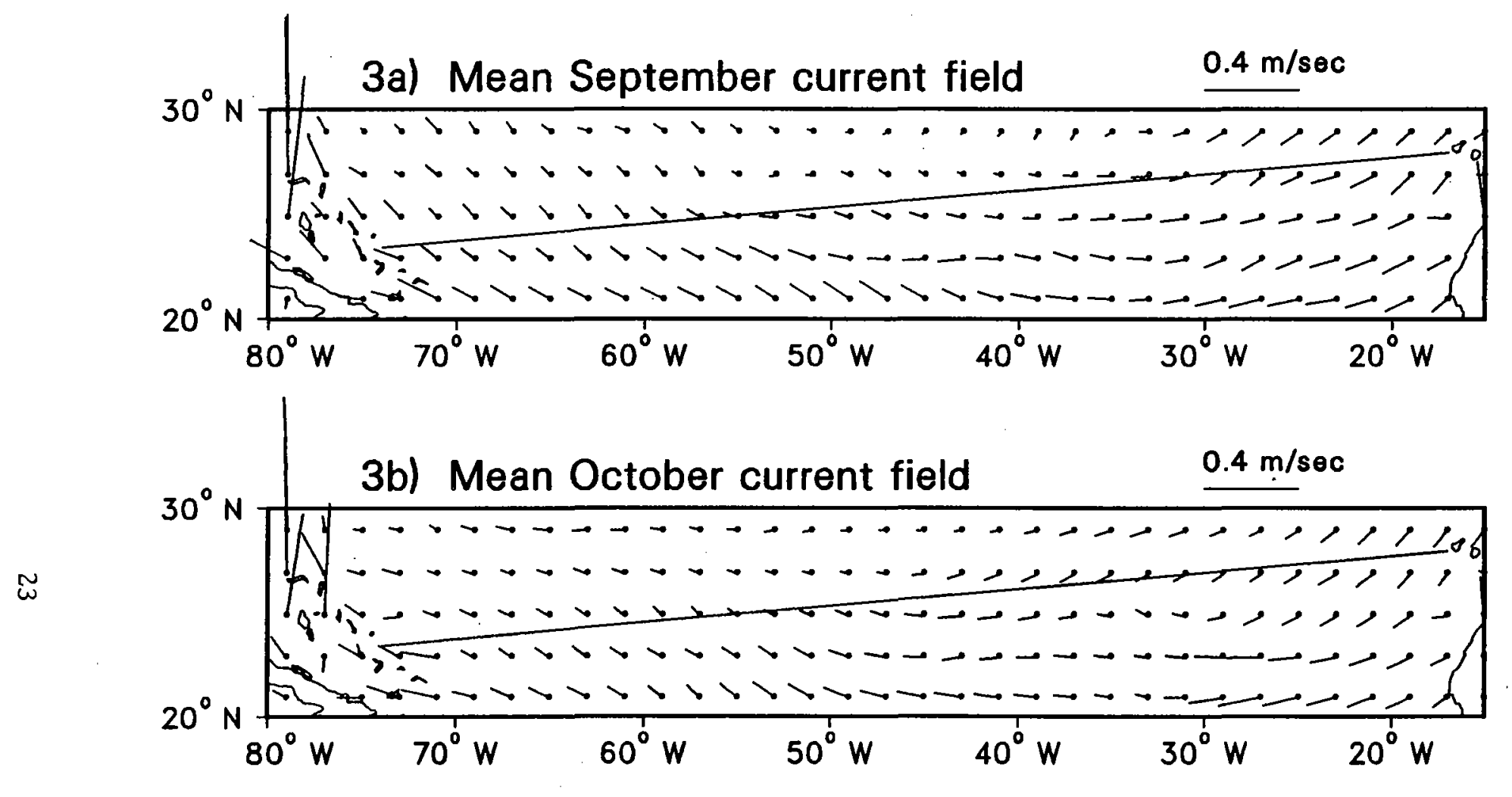

Mean monthly current fields shown at 2 degree subsample.

Taken from historical shipdrift analysis (Mercator projection).

Figure 3a: Mean current field for September.

Figure 3b: Mean current field for October. 

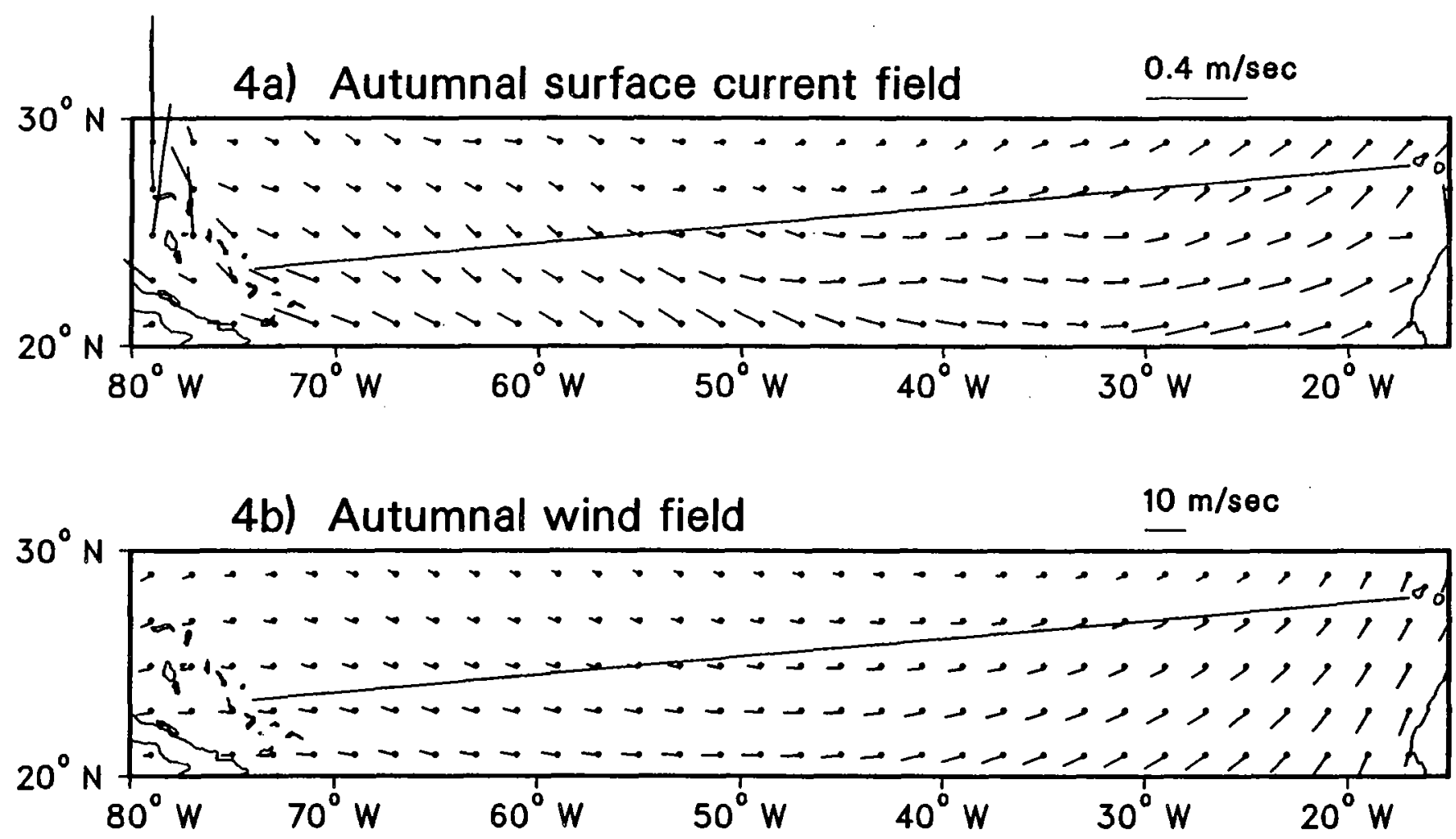

Mean autumnal (September+October) fields shown at 2 degree subsample. (Merçator projection)

Figure 4a: Mean autumnal current field, from historical shipdrift analysis.

Figure 4b: Mean autumnal wind field, from Isemer/Hasse (1985). 
Figure 5: Scenario Endpoints for Columbus Voyage

Chart shows the endpoints of the track as successive corrections are applied. The dashed lines represent the track for the final day of the voyage. (Mercator projection).

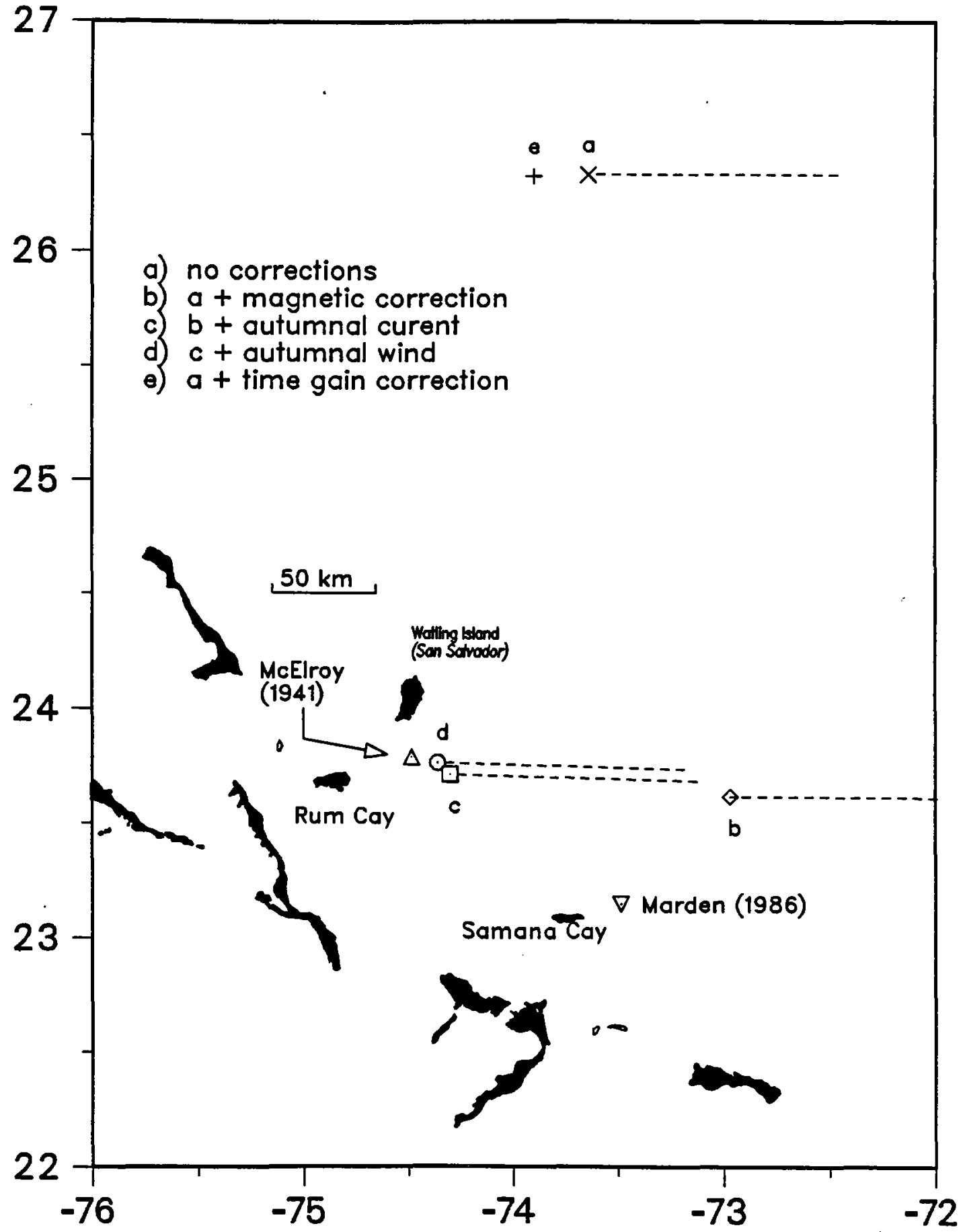


Figure 6: Effect of Various Current and Wind Fields on Columbus Track Termination

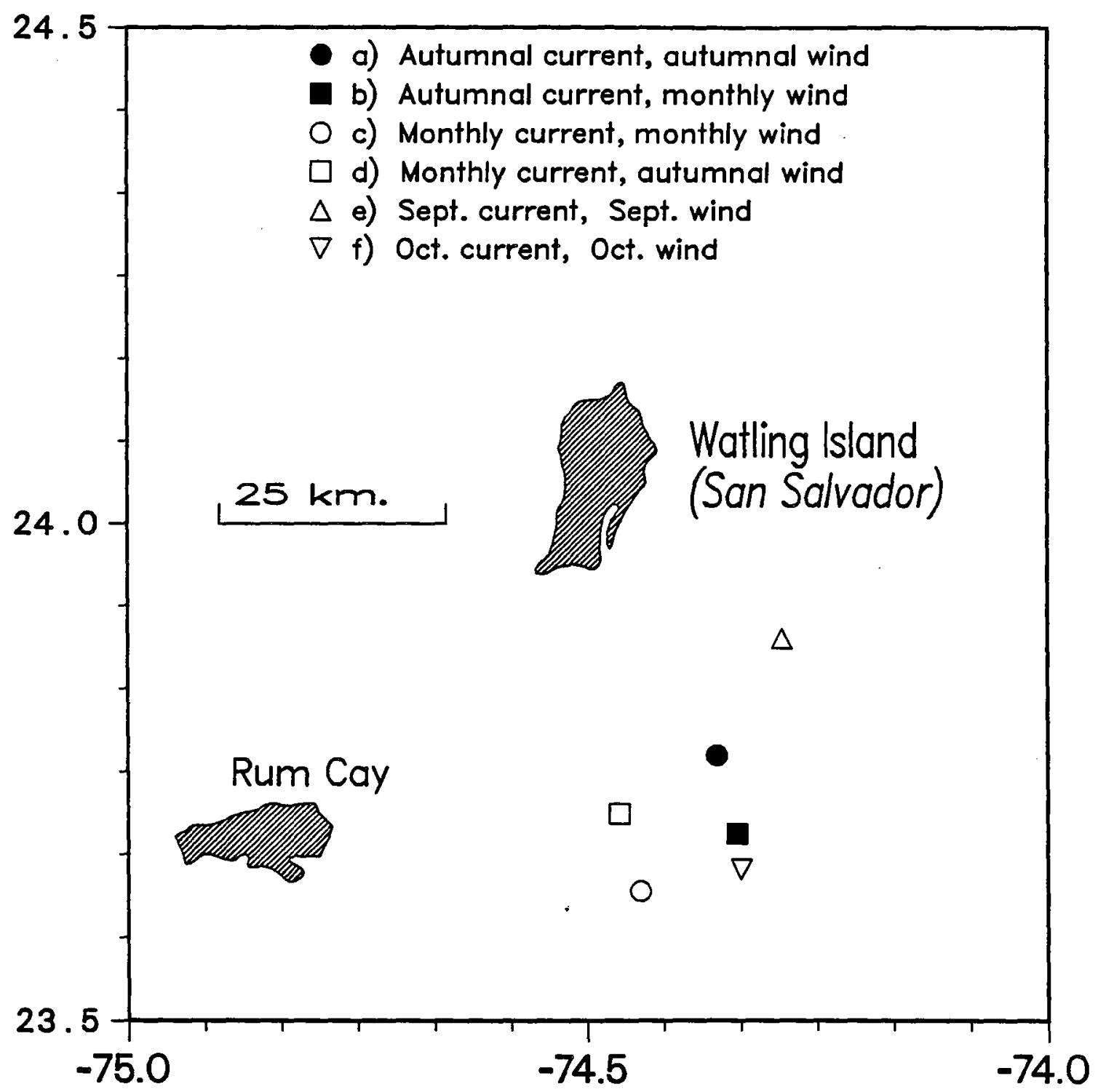

Track endpoints as determined by various current and wind flelds. 'Autumnal' means average over September and October - 'monthly' means the September field was used for the corrected Gregorian date September portion of the voyage, October fields for October dates. All cases used a leeway factor of 0.014. (Mercator projection) 


\section{Figure 7: Effect of Wind and Current Fields on Columbus Track Termination}

Track endpoints showing relative influence of mean autumnal(September and October) wind and current fields. Magnetic corrections and leeway factor $=0.014$ were applied in all coses. (Mercator projection).

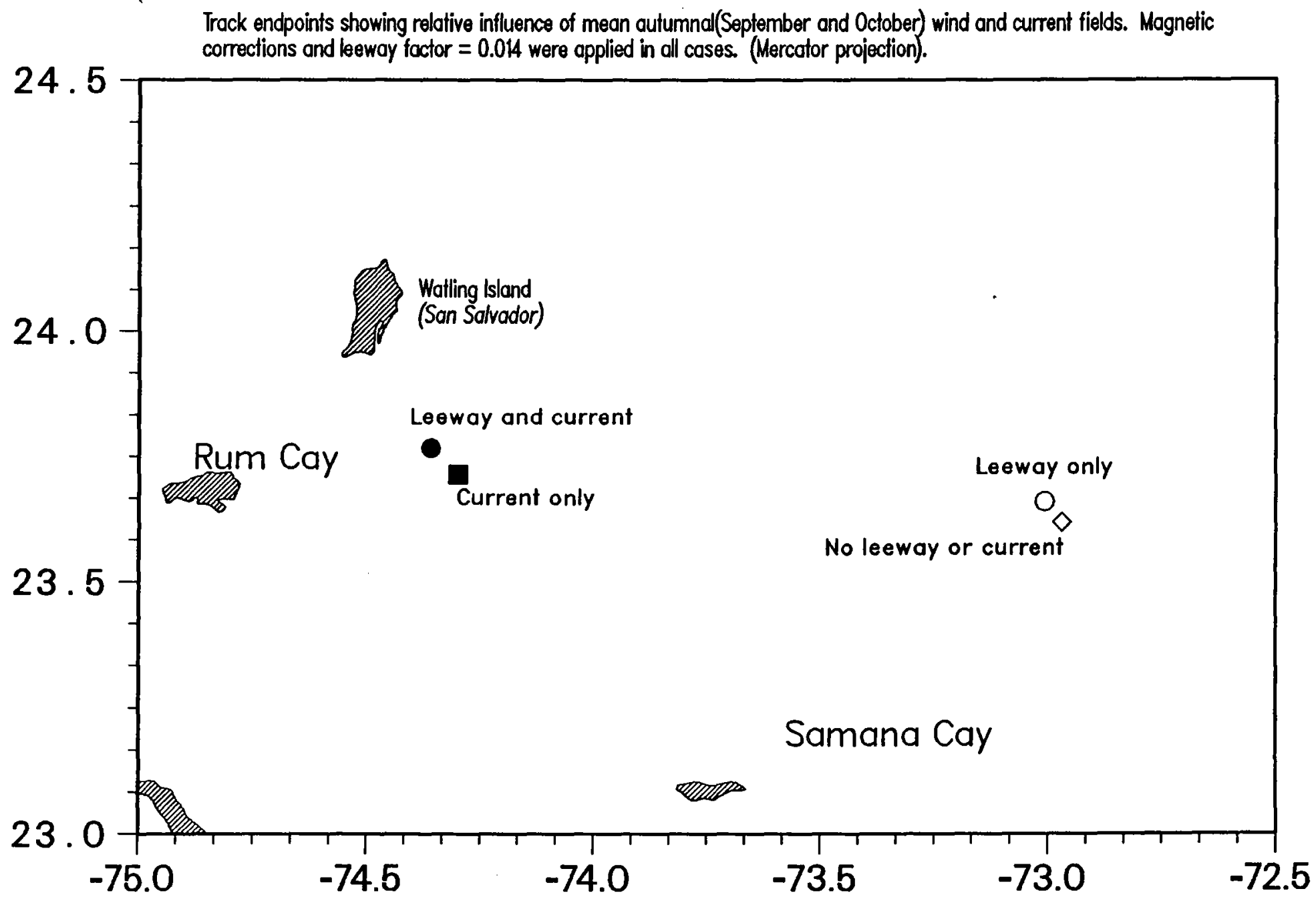


Figure 8: Effect of Varying Leeway Factor on Columbus Track Termination

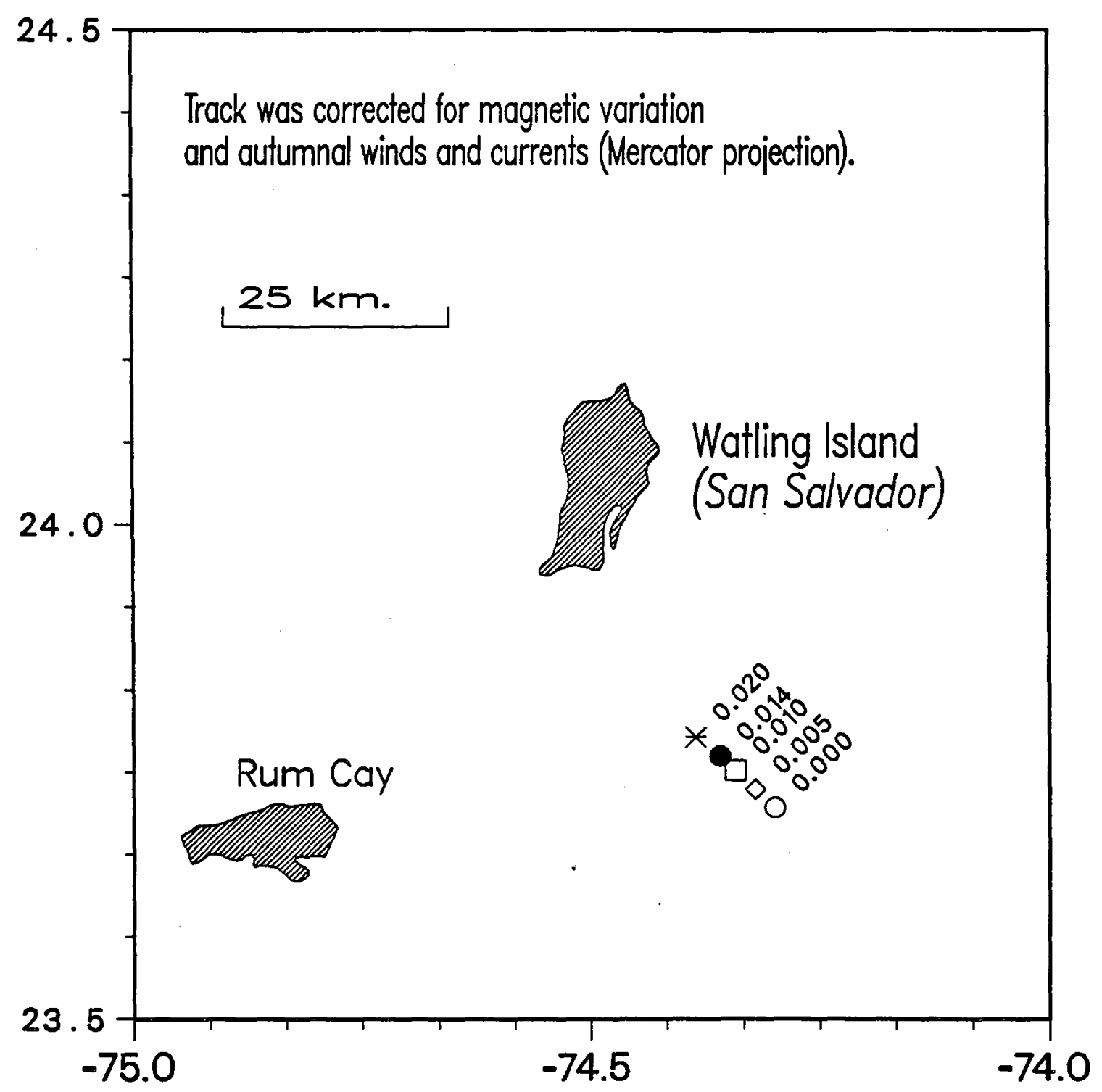




\section{Figure 9: Limited Leeway and Positioning Effects on Columbus Track Termination}

Cumulative effects on track endpoints by removing leeway west of $40 \mathrm{~W}$, using 24 hour computation interval, and great circle positioning. All cases use magnetic correction and leeway factor of 0.014 . (Mercator projection).

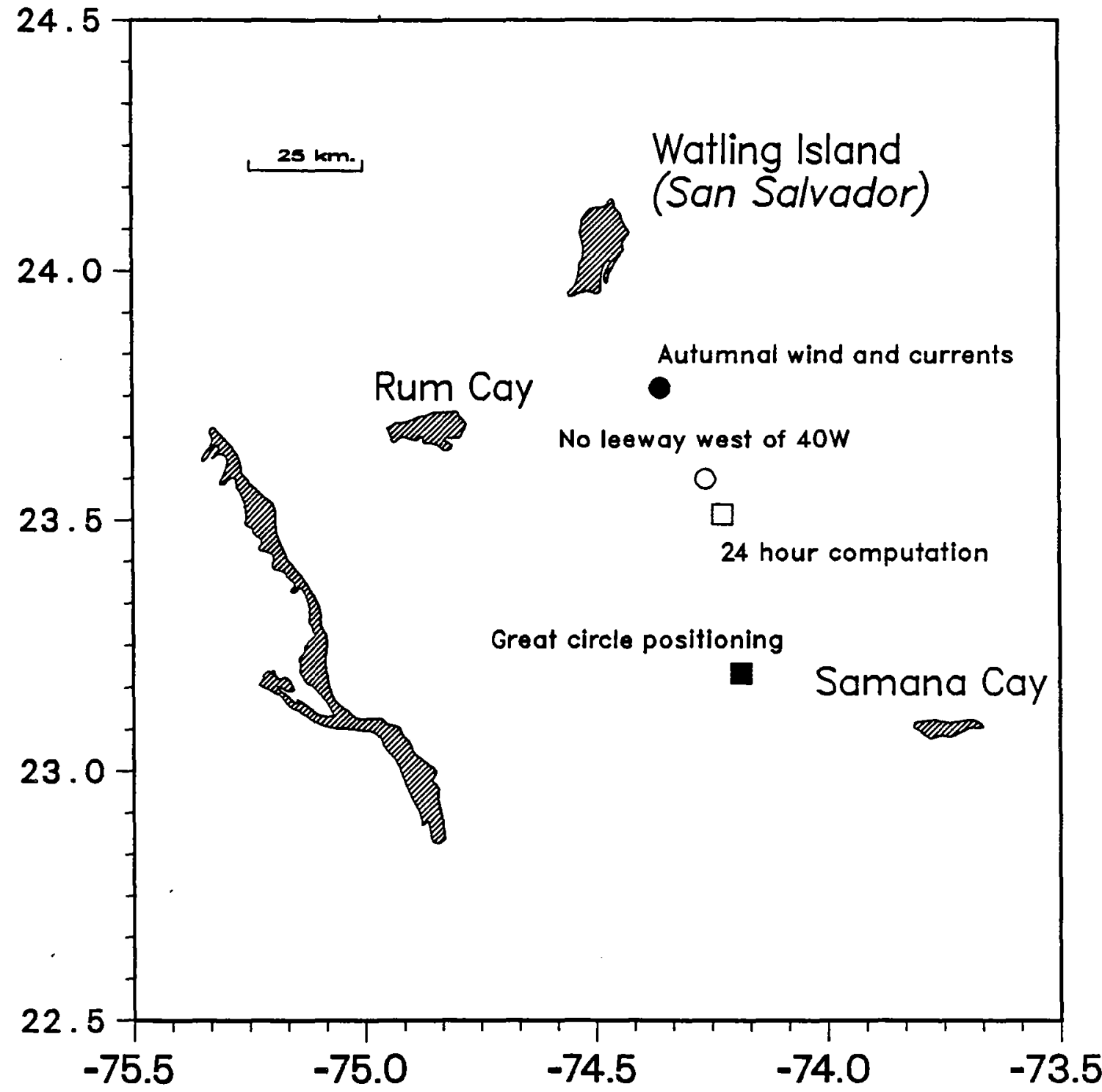


10a) Magnetic variation for 1500 ad.

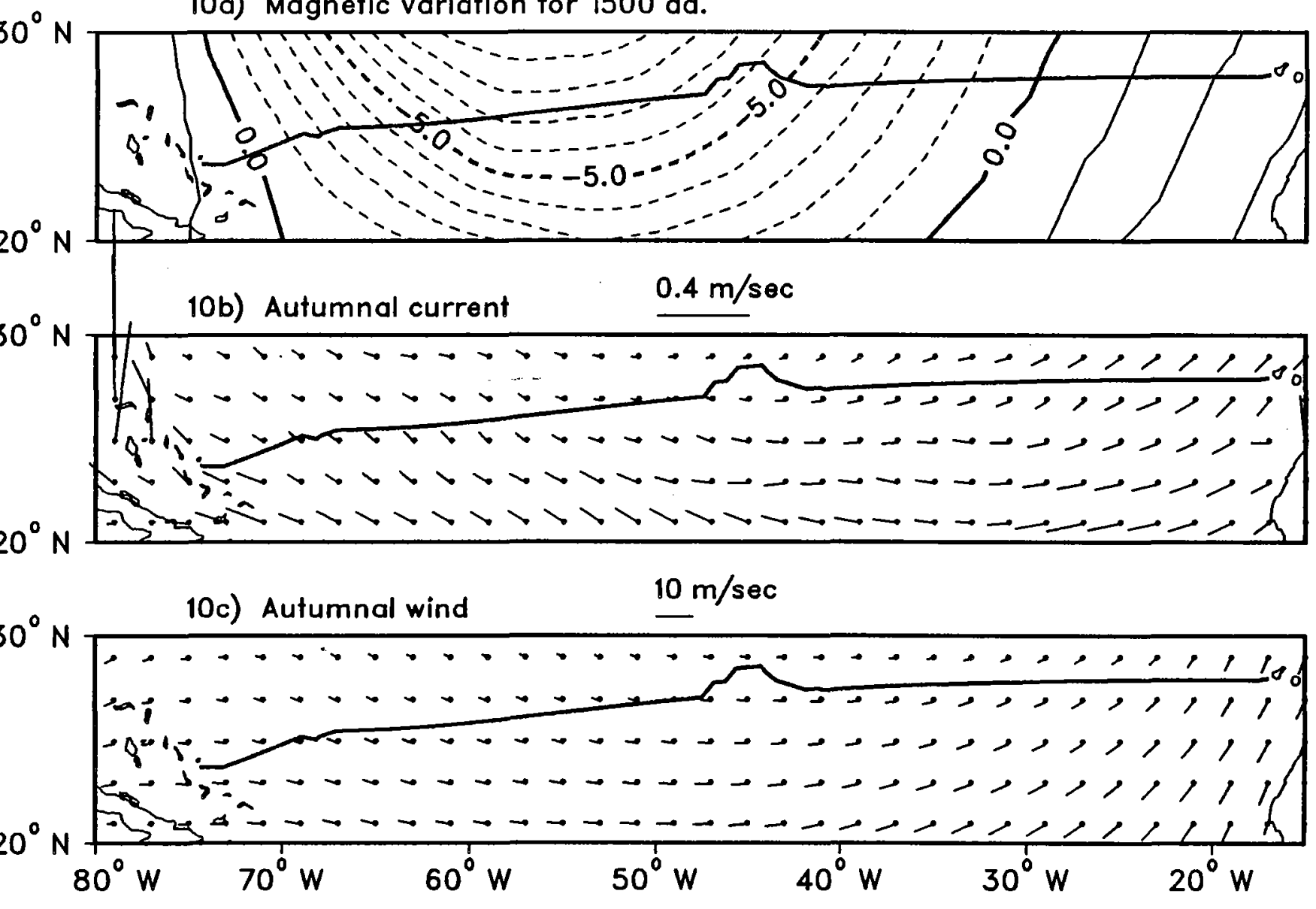

Figures 10: Best corrected track shown through environment fields. Vector fields are shown subsampled every two degrees. Magnetic field taken from van Bemmelen (1899); dashed lines are westward deflections, in degrees. (Mercator projection). 


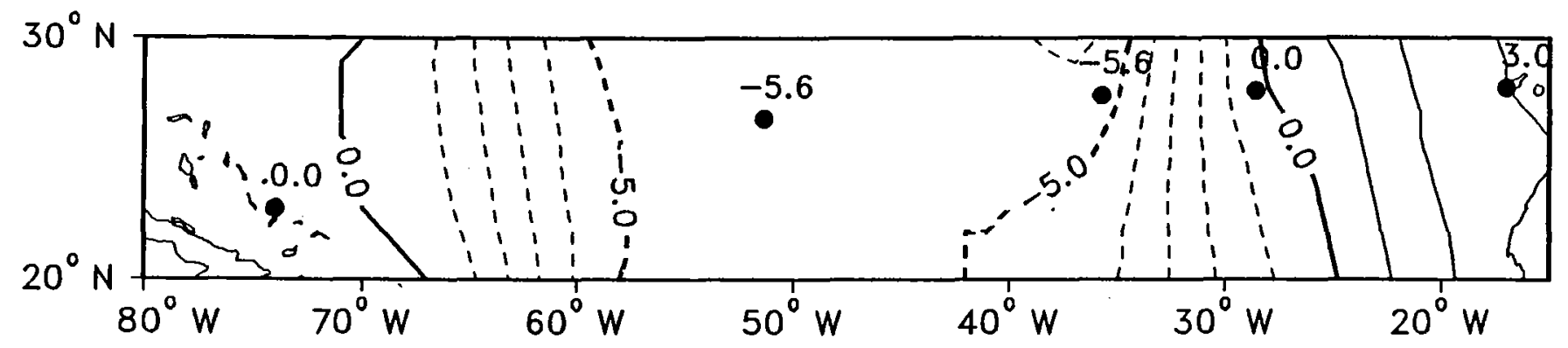

Figure 11a: Magnetic variation (degrees from true north) for the year 1492, constructed from the three observations recorded by Columbus along his track. The value 3.0 for the Canary Islands is from Van Bemmelen (1899); the value for the Bahamas (0.0) is from Schott (1881).

\section{Columbus Course Corrected for 1980 Magnetic Variation}

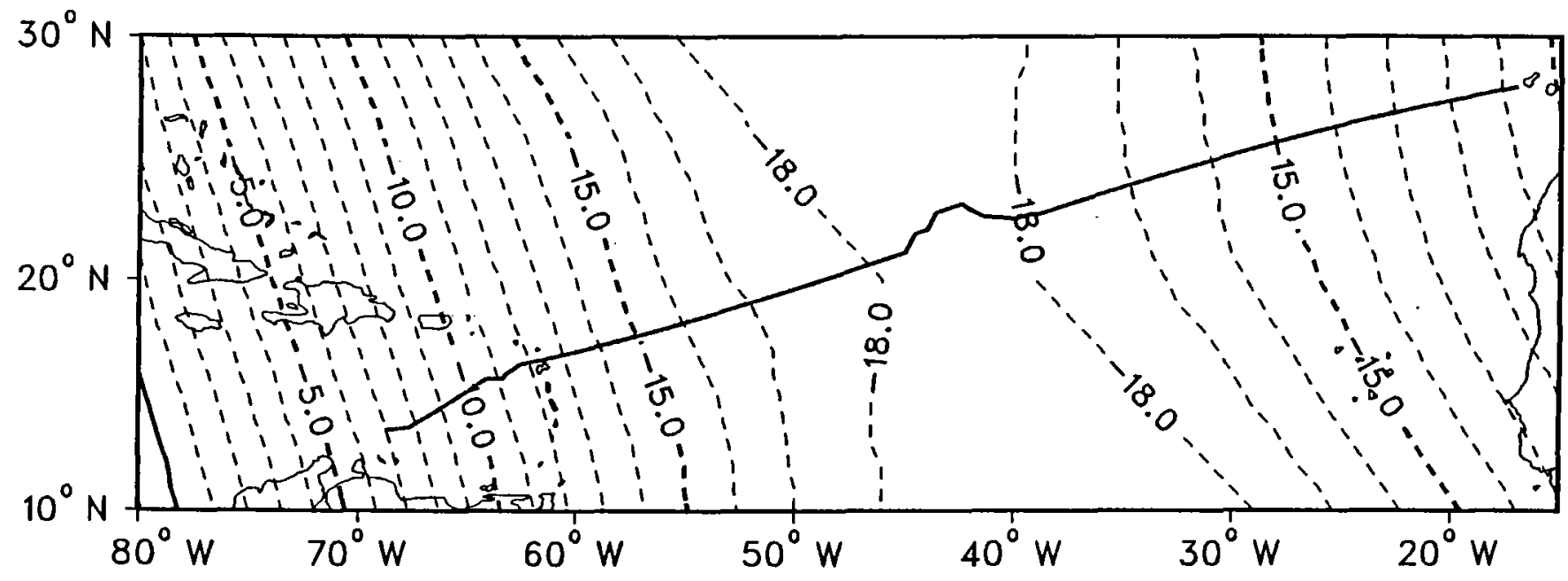

Figure 11b:

Hypothetical track superimposed on the 1980 magnetic variation field.

No current or wind fields were used. Magnetic field was taken from Defense Mapping

Agency chart WOAGN12 (1982). Dashed lines are westward deflections (negative corrections). 
Appendix

CASE SCENARIO SUMMARIES 
Case 01a Course: Columbus log from Marden

Positioning: rhumbline

Computation interval: 30 minutes

Doy lengthening: not used

Mognetic correction: not used

Current field: not used

Wind field:

Leeway wind factor: 0.014

Starting latitude/Longitude position: $28.005 \mathrm{~N} 16.992 \mathrm{~W}$

Starting Day/time: 080300

\begin{tabular}{|c|c|c|c|c|c|c|c|c|c|c|c|c|c|c|}
\hline & & & & urse & & Dista & ance & Cur & & Win & & Norm & Post i & ition \\
\hline on & Da & me & Mag & Var & True & Loag1 & km & $\mathrm{m} / \mathrm{s}$ & dir & $\mathrm{m} / \mathrm{s}$ & dir & Wind & lot & Ion \\
\hline & 09 & & 270.0 & 0.0 & & & 46.99 & & 0.0 & 0.000 & 0.0 & 0.00 & & 470 \\
\hline & 10 & 0600 & & & & & 234. & 0.000 & 0.0 & 0.000 & 0.0 & 0.00 & & 60 \\
\hline & 11 & 0600 & 270.0 & 0.0 & 270.0 & & 313. & 0.000 & 0.0 & 0.000 & 0.0 & 0.00 & 05 & 347 \\
\hline & 12 & 0600 & 270.0 & 0.0 & 270.0 & & 208. & 0.000 & 0.0 & 000 & 0.0 & 0.00 & 05 & 172 \\
\hline $\mathbf{r}$ & 13 & 0600 & 270.0 & 0.0 & $27 e$ & & 172. & 0.000 & 0. & .000 & 0.0 & 0.00 & & \\
\hline Sep & 14 & 0600 & 270.0 & 0.0 & 270.0 & .00 & 172.29 & 0.000 & 0. & $\theta$ & 0.0 & 0.0 & & \\
\hline Sep & 15 & 0600 & 270.0 & 0.0 & 270.0 & 20.00 & 104.42 & 0.000 & 0.0 & .000 & 0.0 & 0.0 & 85 & 740 \\
\hline & $\begin{array}{l}16 \\
17\end{array}$ & $\begin{array}{l}0600 \\
0600\end{array}$ & $\begin{array}{l}270.0 \\
270.0\end{array}$ & $\begin{array}{l}0.0 \\
0.0\end{array}$ & $\begin{array}{l}270.0 \\
270.0\end{array}$ & & $\begin{array}{l}140 . \\
203 .\end{array}$ & $\begin{array}{l}0.000 \\
0.000\end{array}$ & $\begin{array}{l}0.0 \\
0.0\end{array}$ & .000 & $\begin{array}{l}0.0 \\
0.0\end{array}$ & $\begin{array}{l}0.00 \\
0.00\end{array}$ & $\begin{array}{l}85 \\
05\end{array}$ & 174 \\
\hline & 18 & 0600 & 270.0 & 0.0 & 270.0 & & 261.04 & 0.000 & 0.0 & 000 & 0.0 & 0.00 & 28.005 & .902 \\
\hline & 19 & 0600 & 270.0 & & .0 & & 287. & 0.000 & 0.0 & 0.006 & 0.0 & 0.00 & & \\
\hline & 20 & 0600 & 270.0 & & 270.0 & 25.80 & 130.52 & 0.000 & 0.0 & 0.000 & 0.0 & 0.00 & 28.005 & .151 \\
\hline & 20 & 1800 & 281.2 & 0.0 & 281.2 & 3.80 & 19.84 & 0.000 & 0.0 & 0.000 & 0.0 & 0.00 & & .349 \\
\hline & 21 & 0600 & 292.5 & & 292.5 & .80 & 19. & 0.000 & 0.0 & .000 & 0.0 & 0.00 & 08 & .535 \\
\hline & 22 & 0600 & 270.0 & & 270.0 & 13.00 & 67.87 & 0.000 & 0.0 & .000 & 0.0 & 0.00 & 3.108 & -41.227 \\
\hline & 23 & 0600 & 292.5 & & 292.5 & 30.00 & 156.62 & 0.000 & 0.0 & .000 & 0.0 & 0.00 & 46 & -4 \\
\hline & 23 & 1800 & 315.0 & & 315.0 & 13.50 & 70.48 & 0.000 & 0.0 & .000 & 0.0 & 0.00 & .094 & -43.215 \\
\hline & 24 & 0100 & $\begin{array}{l}326 \\
279\end{array}$ & & 326.2 & & 42.29 & 0 & 0.0 & 000 & 0.0 & 0.00 & & 57 \\
\hline & $\begin{array}{l}24 \\
25\end{array}$ & $\begin{array}{l}0600 \\
0600\end{array}$ & $\begin{array}{l}270.0 \\
270.0\end{array}$ & & $\begin{array}{l}270 \\
270\end{array}$ & & $\begin{array}{l}28 \\
75\end{array}$ & $\begin{array}{l}0.000 \\
0.000\end{array}$ & $\begin{array}{l}0.0 \\
0.0\end{array}$ & & $\begin{array}{l}0.0 \\
0.0\end{array}$ & $\begin{array}{l}0.60 \\
0.00\end{array}$ & $\begin{array}{l}410 \\
410\end{array}$ & \\
\hline & 25 & 1800 & 270.0 & & 270.0 & 4.50 & & 0.0 & 0.0 & 0.000 & 0.0 & 0.00 & 410 & \\
\hline & 26 & 0600 & 225.0 & & 225.0 & 17.00 & & 0.000 & 0.0 & 00 & 0.0 & 0.00 & 846 & .416 \\
\hline & 26 & 1500 & 270.0 & & 270.0 & 11.60 & 60. & & 0.0 & & 0.0 & 0.00 & & -4 \\
\hline & 27 & 0600 & 225.0 & & 225.0 & & 101 & & 0.0 & & 0.0 & 0.00 & & 770 \\
\hline & 28 & 0600 & 270.0 & & 270.0 & 00 & 125.30 & 0.000 & 0.0 & .000 & 0.0 & 0.00 & & .047 \\
\hline & 29 & 0600 & 270.0 & 0.0 & 270.0 & 14.00 & 73.09 & 0.000 & 0.0 & 9.000 & 0.0 & 0.00 & 03 & .792 \\
\hline & 30 & 0600 & 270.0 & 0.1 & 270.0 & 24.00 & 125.30 & 0.000 & 0.0 & .006 & 0.0 & 0.00 & 203 & -5 \\
\hline & 01 & 0600 & 270.0 & & 270.0 & & 73. & & 0.0 & & 0.0 & 0.00 & & - \\
\hline & 02 & 0600 & 270.0 & & 270.0 & & 130. & & 0.0 & & 0.0 & 0.00 & & .145 \\
\hline & 03 & 0600 & 270.0 & 0.0 & 270.0 & 00 & 203 & 0.000 & 0.0 & 0.000 & 0.0 & 0.00 & & - \\
\hline & 04 & 0600 & 270.0 & 0. & 270.0 & 00 & 245.38 & 0.000 & 0.0 & 0.000 & 0.0 & 0.00 & 203 & .721 \\
\hline & $\begin{array}{l}05 \\
06\end{array}$ & $\begin{array}{l}0600 \\
0600\end{array}$ & $\begin{array}{l}270.0 \\
270.0\end{array}$ & $\begin{array}{l}0.0 \\
0.0\end{array}$ & $\begin{array}{l}270.0 \\
270.0\end{array}$ & & $\begin{array}{l}328 \\
297\end{array}$ & $\begin{array}{l}0.0 \\
0.0\end{array}$ & $\begin{array}{l}0.0 \\
0.0\end{array}$ & $\begin{array}{l}\theta 0 \\
0 \theta\end{array}$ & $\begin{array}{l}0.0 \\
0.0\end{array}$ & $\begin{array}{l}0.00 \\
0.00\end{array}$ & & $\begin{array}{l}-6 \\
-6\end{array}$ \\
\hline & 07 & 0600 & 270.0 & 0.0 & 270.0 & 40.00 & 208.83 & 0.0 & 0.0 & 0.0 & 0.0 & 0.00 & 203 & -6 \\
\hline & 07 & 1700 & 270.0 & 0.0 & 270.0 & 23.00 & 120.08 & 0.000 & 0.0 & 0.0 & 0.0 & 0.00 & & -6 \\
\hline & 08 & 0600 & 247.5 & 0.0 & 247.5 & 5.00 & 26. & 0.000 & 0.0 & 0.000 & 0.0 & 0.00 & 113 & .705 \\
\hline & 09 & 0600 & & & 247.5 & 11.80 & 01. & & 0.0 & & 0.0 & & 901 & 284 \\
\hline & 09 & 1200 & 225.0 & 0.0 & 225.0 & & & & 0.0 & & 0.0 & & & \\
\hline & 10 & 0600 & 281.2 & 0.0 & 281.2 & & 80.92 & & 0.0 & & 0.0 & & & 278 \\
\hline & 11 & $\begin{array}{l}0600 \\
1800\end{array}$ & & 0.0 & $\begin{array}{l}247.5 \\
247.5\end{array}$ & $\begin{array}{l}59.00 \\
27.00\end{array}$ & $\begin{array}{l}308.03 \\
140.96\end{array}$ & 0.000 & 0.0 & & $\begin{array}{l}0.0 \\
0.0\end{array}$ & .00 & & \\
\hline & 12 & $\begin{array}{l}1800 \\
0200\end{array}$ & 270.0 & 0.0 & $\begin{array}{l}247.5 \\
270.0\end{array}$ & 22.50 & $\begin{array}{l}140.96 \\
117.47\end{array}$ & 0.000 & $\begin{array}{l}0.0 \\
0.0\end{array}$ & 0.000 & $\begin{array}{l}0.0 \\
0.0\end{array}$ & $\begin{array}{l}0.00 \\
0.00\end{array}$ & $\begin{array}{l}.333 \\
.333\end{array}$ & $\begin{array}{l}.464 \\
.641\end{array}$ \\
\hline & & & 270.0 & 0.0 & 270.0 & 22.00 & 118.98 & & & & & & & \\
\hline
\end{tabular}

Notes: Magnetic field measurements are in degrees; westward deflections are negative.

Ali positions are in degrees, north ond east being positive from the equator and Greenwich Meridian respectively.

Normal winds are in meters/sec.

All dates are as recorded in Columbus's log, Julian calendar. 
Case 01b: Course: Columbus log from Marden

Positioning: rhumbline

Computation intervol: 30 minutes

Day lengthening: not used

Magnetic correction: van Bemmelen for 1500 ad.

Current field: not used

Wind field: not used Leeway wind factor: 0.014

Starting latitude/Longitude position: $28.005 \mathrm{~N} \quad 16.992 \mathrm{~W}$

Starting Day/time: 080300

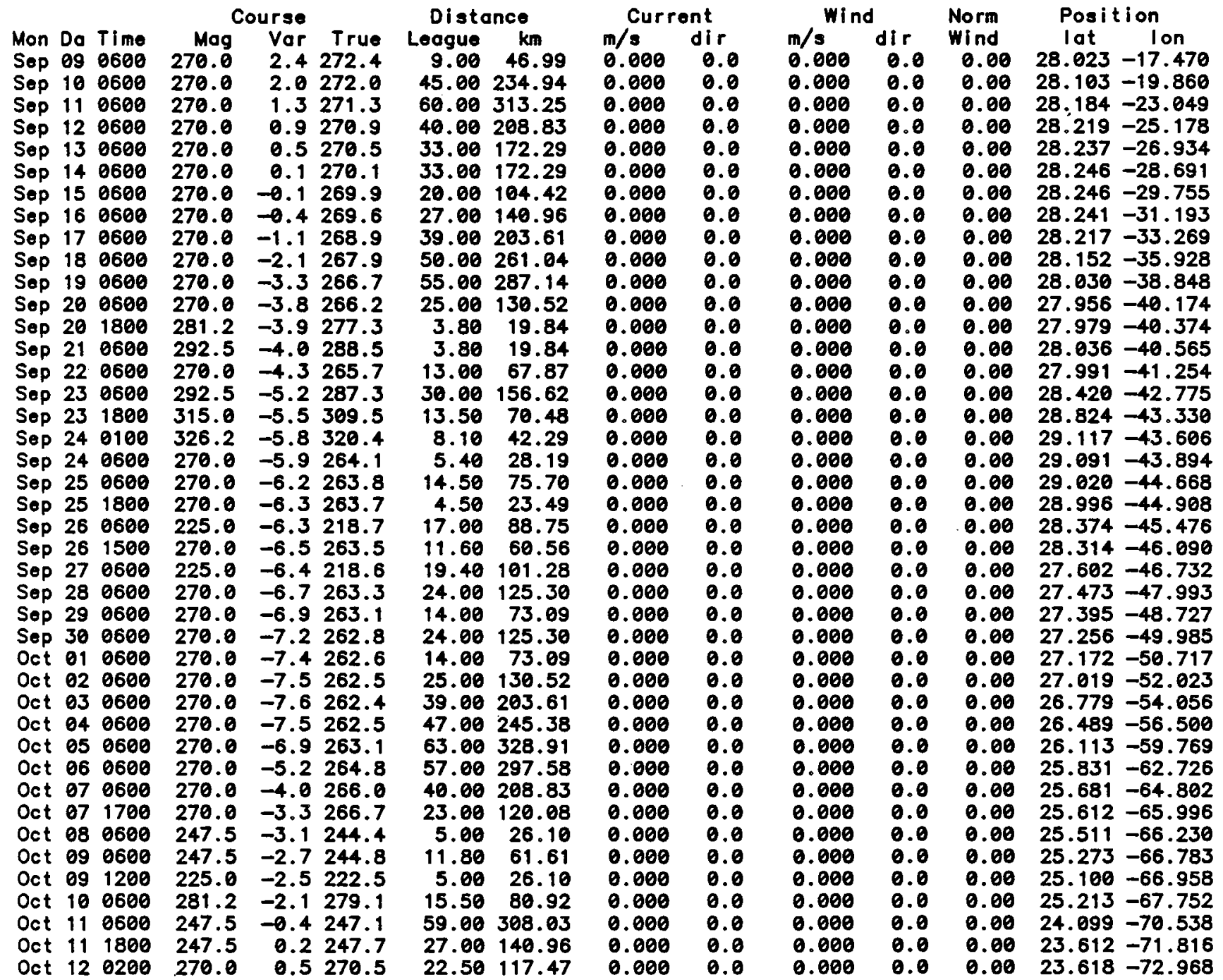

Notes: Magnetic field measurements are in degrees; westward deflections are negative.

All positions are in degrees, north and east being positive from the equator and Greenwich Meridian respectively.

Normal winds are in meters/sec.

All dates are as recorded in Columbus's log, Julian calendar. 
Case 01c: Course: Columbus log from Marden

Positioning: rhumbline

Computation interval: 30 minutes

Day lengthening: not used

Magnetic correction: van Bemmelen for 1500 ad.

Current field: autumnal

Wind field: not used Leeway wind factor: 0.014

Starting latitude/Longitude position: $28.005 \mathrm{~N} 16.992 W$

Starting Day/time: 080300

\begin{tabular}{|c|c|c|c|c|c|c|c|}
\hline & & & & ourse & & Disto & unce \\
\hline & Da & Time & Mog & Var & True & Leogue & km \\
\hline & 09 & 0600 & 270.0 & & 272.4 & 9.00 & 46.99 \\
\hline & 10 & 0600 & 270.0 & & 272.0 & 45.00 & 234.94 \\
\hline & 11 & 0600 & 270.0 & & 271 & 60.00 & 313.25 \\
\hline p & 12 & 0600 & 270.0 & & 270.8 & 40.00 & 208.83 \\
\hline & 13 & 0600 & 270.0 & & 270.5 & 33.00 & 172.29 \\
\hline & $\begin{array}{l}14 \\
15\end{array}$ & $\begin{array}{l}0600 \\
0600\end{array}$ & $\begin{array}{l}270.0 \\
270.0\end{array}$ & & $\begin{array}{l}270.1 \\
269.9\end{array}$ & $\begin{array}{l}33.06 \\
20.00\end{array}$ & $\begin{array}{l}172.29 \\
104.42\end{array}$ \\
\hline & 16 & 0600 & 270.0 & & 269.5 & 27.00 & 140.96 \\
\hline & 17 & 0600 & 270.0 & & 268.8 & 39.00 & 203.61 \\
\hline & 18 & 0600 & 270.0 & & 267.8 & 50.00 & 261.04 \\
\hline & 19 & 0600 & 270.0 & & 266.6 & 55.00 & 287.14 \\
\hline & 20 & 0600 & 270.0 & & 266.1 & 25.00 & 130.52 \\
\hline & 20 & 1800 & 281.2 & -4 & 277.2 & 3.80 & 19.84 \\
\hline & 21 & 0600 & 292.5 & -4 & 288.3 & 3.80 & 19.84 \\
\hline & 22 & 0600 & 270.0 & & 265.5 & 13.00 & $\begin{array}{r}67.87 \\
\end{array}$ \\
\hline & $\begin{array}{l}23 \\
23\end{array}$ & $\begin{array}{l}0600 \\
1800\end{array}$ & $\begin{array}{l}292.5 \\
315.0\end{array}$ & & $\begin{array}{l}287.2 \\
309.3\end{array}$ & $\begin{array}{l}30.00 \\
13.50\end{array}$ & $\begin{array}{r}156.62 \\
70.48\end{array}$ \\
\hline & 24 & 0100 & 326.2 & & 320.3 & 8.10 & 42.29 \\
\hline & 24 & 0600 & 270.0 & -6 & 263.9 & 5.40 & 28.19 \\
\hline & 25 & 0600 & 270.0 & & 263.6 & 14.50 & 75.70 \\
\hline & $\begin{array}{l}25 \\
26\end{array}$ & $\begin{array}{l}1800 \\
0600\end{array}$ & $\begin{array}{l}270.0 \\
225.0\end{array}$ & & $\begin{array}{l}263.5 \\
218.6\end{array}$ & $\begin{array}{r}4.50 \\
17.00\end{array}$ & $\begin{array}{l}23.49 \\
88.75\end{array}$ \\
\hline & 26 & 1500 & 270.0 & -6.6 & 263.4 & 11.60 & 60.56 \\
\hline & 27 & 0600 & 225.0 & & 218.5 & 19.40 & 101.28 \\
\hline & 28 & 0600 & 270.0 & & 263.2 & 24.00 & 125.30 \\
\hline & 29 & 0600 & 270.0 & & 263.0 & 14.00 & 73.09 \\
\hline & 30 & 0600 & 270.0 & & $\begin{array}{l}262.7 \\
262.6\end{array}$ & & 125.30 \\
\hline & 02 & $\begin{array}{l}0600 \\
0600\end{array}$ & $\begin{array}{l}270.0 \\
270.0\end{array}$ & $\begin{array}{l}-7 \\
-7\end{array}$ & $\begin{array}{l}262.6 \\
262.6\end{array}$ & $\begin{array}{l}14.00 \\
25.00\end{array}$ & $\begin{array}{r}73.09 \\
130.52\end{array}$ \\
\hline ct & 03 & 0600 & 270.0 & -7 . & 262.6 & 39.00 & 203.61 \\
\hline & 04 & 0600 & 270.0 & & 262.7 & .00 & 245.38 \\
\hline & 05 & 0600 & 270.0 & & 263.7 & 63.00 & 328.91 \\
\hline & 06 & 0600 & 270.0 & & 265.5 & 57.00 & 297.58 \\
\hline & 07 & $\begin{array}{l}0600 \\
1700\end{array}$ & 270.0 & & $\begin{array}{l}266.7 \\
267.3\end{array}$ & 40.00 & 208.83 \\
\hline & $\begin{array}{l}07 \\
08\end{array}$ & $\begin{array}{l}1700 \\
0600\end{array}$ & $\begin{array}{l}270.0 \\
247.5\end{array}$ & $\begin{array}{l}-2.7 \\
-2.5\end{array}$ & $\begin{array}{l}267.3 \\
245.0\end{array}$ & $\begin{array}{r}23.00 \\
5.00\end{array}$ & $\begin{array}{r}120.08 \\
26.10\end{array}$ \\
\hline$t$ & 09 & 0600 & 247.5 & -2.1 & 245.4 & 11.80 & 61.61 \\
\hline$t$ & 09 & 1200 & 225.0 & -1.9 & 223.1 & 5.00 & 26.10 \\
\hline 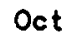 & 10 & 0600 & 281.2 & -1 & 279.7 & 15.50 & 80.92 \\
\hline & 11 & 0600 & 247.5 & & 247.6 & 59.00 & 308.0 \\
\hline & 11 & 1800 & 247.5 & & 248.0 & $\begin{array}{l}27.00 \\
22.50\end{array}$ & 140.9 \\
\hline & & & & 0.5 & 270.9 & 22.56 & \\
\hline
\end{tabular}

\begin{tabular}{ll}
\multicolumn{2}{c}{ Current } \\
m/s & dir \\
0.084 & 222.0 \\
0.089 & 231.4 \\
0.089 & 242.4 \\
0.076 & 239.2 \\
0.067 & 236.4 \\
0.063 & 242.0 \\
0.062 & 247.3 \\
0.063 & 254.3 \\
0.060 & 256.3 \\
0.054 & 250.7 \\
0.045 & 252.8 \\
0.042 & 256.7 \\
0.041 & 257.2 \\
0.040 & 257.5 \\
0.039 & 260.0 \\
0.032 & 263.7 \\
0.028 & 262.4 \\
0.026 & 259.9 \\
0.026 & 260.7 \\
0.026 & 263.9 \\
0.027 & 265.0 \\
0.032 & 275.6 \\
0.032 & 279.4 \\
0.038 & 289.2 \\
0.038 & 288.6 \\
0.037 & 286.1 \\
0.036 & 281.4 \\
0.036 & 278.6 \\
0.038 & 279.5 \\
0.044 & 294.7 \\
0.052 & 307.7 \\
0.059 & 308.5 \\
0.061 & 308.4 \\
0.060 & 306.2 \\
0.060 & 304.6 \\
0.062 & 304.7 \\
0.065 & 304.9 \\
0.067 & 305.3 \\
0.069 & 307.0 \\
0.097 & 303.6 \\
0.103 & 303.4 \\
0.088 & 315.4 \\
0 &
\end{tabular}

\begin{tabular}{|c|c|c|c|c|}
\hline Wir & & Norm & Posi & ion \\
\hline $\begin{array}{l}\mathrm{m} / \mathrm{s} \\
0.000\end{array}$ & & Wind & lat & Ion \\
\hline $\begin{array}{l}0.000 \\
0.000\end{array}$ & $\begin{array}{l}0.0 \\
0.0\end{array}$ & $\begin{array}{l}0.00 \\
0.00\end{array}$ & $\begin{array}{l}27.970 \\
28.003\end{array}$ & $\begin{array}{l}-17.523 \\
-19.967\end{array}$ \\
\hline 0.000 & 0.0 & 0.00 & 28.047 & -23.220 \\
\hline 0.000 & 0.0 & 0.00 & 28.049 & -25.409 \\
\hline $\begin{array}{l}0.000 \\
0.000\end{array}$ & 0.0 & 0.00 & 28.037 & $\begin{array}{l}-27.215 \\
-29\end{array}$ \\
\hline 0.000 & 0.0 & 0.00 & 27.998 & -30.128 \\
\hline 0.000 & 0.0 & 0.00 & 27.976 & -31.614 \\
\hline 0.000 & 0.0 & 0.00 & 27.937 & -33.737 \\
\hline 0.000 & 0.0 & 0.00 & $\begin{array}{l}27.855 \\
27.715\end{array}$ & $\begin{array}{l}-36.437 \\
-39.390\end{array}$ \\
\hline $\begin{array}{l}0.000 \\
0.000\end{array}$ & $\begin{array}{l}0.0 \\
0.0\end{array}$ & $\begin{array}{l}0.00 \\
0.00\end{array}$ & 27.630 & -40.748 \\
\hline 0.000 & 0.0 & 0.00 & 27.649 & -40.965 \\
\hline 0.000 & 0.0 & 0.00 & 27.702 & -41.174 \\
\hline 0.000 & 0.0 & 0.00 & 27.650 & -41.894 \\
\hline $\begin{array}{l}0.000 \\
0.000\end{array}$ & $\begin{array}{l}0.0 \\
0.0\end{array}$ & $\begin{array}{l}0.06 \\
0.00\end{array}$ & $\begin{array}{l}28.072 \\
28.473\end{array}$ & $\begin{array}{l}-43.441 \\
-44.009\end{array}$ \\
\hline 0.000 & 0.0 & 0.00 & 28.765 & -44.292 \\
\hline 0.000 & 0.0 & 0.00 & 28.738 & 44.584 \\
\hline 0.000 & 0.0 & 0.00 & 28.661 & -45.378 \\
\hline 0.000 & $\begin{array}{l}0.0 \\
0.0\end{array}$ & $\begin{array}{l}0.00 \\
0.00\end{array}$ & $\begin{array}{l}28.636 \\
28.013\end{array}$ & $\begin{array}{l}-45.628 \\
-46.206\end{array}$ \\
\hline $\begin{array}{l}0.0000 \\
0.000\end{array}$ & 0.0 & 0.00 & 27.953 & -46.828 \\
\hline 0.000 & 0.0 & 0.00 & 27.245 & -47.485 \\
\hline 0.000 & 0.0 & 0.00 & 27.125 & -48.773 \\
\hline 0.000 & 0.0 & 0.00 & .055 & .536 \\
\hline 0.000 & 0.0 & .00 & 26.921 & -50.820 \\
\hline 0.000 & 0.0 & 0.00 & .842 & -51.581 \\
\hline 0.000 & 0.0 & 0.00 & .696 & $\begin{array}{l}-52.915 \\
-54\end{array}$ \\
\hline $\begin{array}{l}0.006 \\
0.000\end{array}$ & $\begin{array}{l}0.0 \\
0.0\end{array}$ & $\begin{array}{l}0.00 \\
0.00\end{array}$ & $\begin{array}{l}.469 \\
.205\end{array}$ & $\begin{array}{l}-54.977 \\
-57.451\end{array}$ \\
\hline 0.000 & 0.0 & 0.00 & 25.875 & -60.753 \\
\hline 0.000 & 0.0 & 0.00 & 25.653 & -63.748 \\
\hline 0.000 & 0.0 & 0.00 & .553 & -65.865 \\
\hline 0.000 & 0.0 & 0.00 & 509 & -67.078 \\
\hline 0.000 & 0.0 & 0.00 & 425 & -67.337 \\
\hline 0.000 & 0.0 & 0.00 & 25.221 & -67.937 \\
\hline $\begin{array}{l}0.000 \\
0.000\end{array}$ & $\begin{array}{l}0.0 \\
0.0\end{array}$ & $\begin{array}{l}0.00 \\
0.00\end{array}$ & $\begin{array}{l}25.057 \\
25.200\end{array}$ & $\begin{array}{l}-68.126 \\
-68.953\end{array}$ \\
\hline 0.000 & 0.0 & 0.00 & 24.140 & -71.807 \\
\hline 0.000 & 0.0 & 0.00 & .686 & -73.126 \\
\hline & & & & \\
\hline
\end{tabular}

Notes: Magnetic field measurements are in degrees; westword deflections are negative. Ali positions are in degrees, north and east being positive from the equator and Greonwich Meridian respectively.

Normal winds are in meters/sec.

All dates are as recorded in Columbus's log, Julian calendar. 
Case 01d: Course: Columbus log from Marden

Positioning: rhumbline

Computation interval: 30 minutes

Day lengthening: not used

Magnetic correction: van Bemmelen for 1500 ad.

Curront field: autumnal

Wind field: autumnal Leeway wind foctor: 0.014

Starting latitude/Longitude position: $28.005 \mathrm{~N} 16.992 \mathrm{~W}$

Starting Day/time: 080300

\begin{tabular}{|c|c|c|c|c|c|c|c|}
\hline & & & & ourse & & Dista & ance \\
\hline - & Da & & & Var & True & & $\mathbf{k m}$ \\
\hline & 69 & 0600 & 270.0 & & 272.4 & 9.00 & 46.99 \\
\hline & 10 & 0600 & 270.0 & & 272.0 & 45.00 & 234.94 \\
\hline & 11 & 0600 & 270.0 & & 271.3 & 60.00 & 313.25 \\
\hline & 12 & 0600 & $\begin{array}{l}270.0 \\
270.0\end{array}$ & .8 & 270.8 & 40.00 & $\begin{array}{l}208.83 \\
172.29\end{array}$ \\
\hline & 14 & 0600 & 270.0 & 0.1 & 270.1 & 33.00 & 172.29 \\
\hline & 15 & 0600 & 270.0 & & 269.9 & 20.00 & 104.42 \\
\hline & 16 & 0600 & 270.0 & & 269.5 & 27.00 & 140.96 \\
\hline & $\begin{array}{l}17 \\
18\end{array}$ & 0600 & 270.0 & $\begin{array}{l}-1 \\
-2\end{array}$ & $\begin{array}{l}268.8 \\
267\end{array}$ & 39.00 & 203.61 \\
\hline & $\begin{array}{l}10 \\
19\end{array}$ & 0600 & 270.0 & -2.3 & 266.7 & 55.00 & $\begin{array}{l}261.64 \\
287.14\end{array}$ \\
\hline & 20 & 0600 & 270.0 & & 266.1 & 25.00 & 130.52 \\
\hline & 20 & 1800 & 281.2 & & 277.2 & 3.80 & 19.84 \\
\hline & $\begin{array}{l}21 \\
22\end{array}$ & $\begin{array}{l}0600 \\
0600\end{array}$ & 292.5 & & 288.4 & $\begin{array}{r}3.80 \\
13.00\end{array}$ & $\begin{array}{l}19.84 \\
67.87\end{array}$ \\
\hline & 23 & 0600 & 292.5 & & 287.3 & 30.00 & 156.62 \\
\hline & 23 & 1800 & 315.0 & & 309.4 & 13.50 & 70.48 \\
\hline & 24 & 0100 & 326.2 & -5 & 320.4 & 8.10 & 42.29 \\
\hline & 24 & 0600 & 270.0 & - & 264.0 & 5.40 & 28.19 \\
\hline & 25 & 0600 & 270.0 & - & 263.7 & 14.50 & 75.70 \\
\hline & $\begin{array}{l}25 \\
26\end{array}$ & $\begin{array}{l}1800 \\
9600\end{array}$ & 270.0 & $\begin{array}{l}-6 \\
-6\end{array}$ & 263.6 & $\begin{array}{r}4.50 \\
17.99\end{array}$ & $\begin{array}{l}23.49 \\
88.75\end{array}$ \\
\hline & 26 & 1500 & 270.0 & -6.5 & 263.5 & 11.60 & 60.56 \\
\hline & 27 & 0600 & 225.0 & & 218.6 & 19.40 & 101.28 \\
\hline & 28 & 0600 & 270.0 & -6 & 263.3 & 4.00 & 125.30 \\
\hline & 29 & 0600 & 270.0 & & 263.1 & 14.00 & \\
\hline & $\begin{array}{l}30 \\
01\end{array}$ & $\begin{array}{l}0600 \\
0600\end{array}$ & $\begin{array}{l}270.0 \\
270.0\end{array}$ & & & & $\begin{array}{r}125 \\
73\end{array}$ \\
\hline & 02 & 0600 & 270.0 & -7 & $\begin{array}{l}202.7 \\
262.7\end{array}$ & $\begin{array}{l}14.60 \\
25.00\end{array}$ & 130.52 \\
\hline & 03 & 0600 & 270.0 & & 262.6 & 39.00 & 203.61 \\
\hline & 04 & 0600 & 270.0 & & 262.7 & & 245.38 \\
\hline & 05 & 0600 & 270.0 & & 263.8 & & 328 \\
\hline & 06 & 0600 & 270.0 & & 265.5 & .00 & 297.58 \\
\hline & 07 & 0600 & 270.0 & -3.3 & 266.7 & 40.00 & 208.83 \\
\hline & 07 & $\begin{array}{l}1700 \\
8600\end{array}$ & $\begin{array}{l}270.0 \\
247.5\end{array}$ & $\begin{array}{l}-2.7 \\
-2.5\end{array}$ & 267.3 & 23.00 & $\begin{array}{r}120.08 \\
26\end{array}$ \\
\hline & 09 & 0600 & $\begin{array}{l}247.5 \\
247.5\end{array}$ & $\begin{array}{l}-2.0 \\
-2.0\end{array}$ & 245.5 & $\begin{array}{r}5.60 \\
11.80\end{array}$ & $\begin{array}{l}26.10 \\
61.61\end{array}$ \\
\hline & 09 & & 225.0 & & & & 26.10 \\
\hline & & 0600 & 281.2 & -1.5 & 9.7 & 15.50 & 80 \\
\hline & 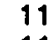 & & & & & & \\
\hline & $\begin{array}{l}11 \\
12\end{array}$ & $\begin{array}{l}1800 \\
0200\end{array}$ & $\begin{array}{l}247.5 \\
270.0\end{array}$ & & $\begin{array}{l}248.1 \\
270.9\end{array}$ & $\begin{array}{l}27.00 \\
22.50\end{array}$ & $\begin{array}{l}140.96 \\
117.47\end{array}$ \\
\hline & & & & & & & \\
\hline
\end{tabular}

\begin{tabular}{ll}
\multicolumn{2}{c}{ Current } \\
m/s & di r \\
0.084 & 221.8 \\
0.089 & 231.5 \\
0.090 & 243.1 \\
0.076 & 239.5 \\
0.065 & 235.9 \\
0.062 & 241.4 \\
0.061 & 246.8 \\
0.063 & 253.8 \\
0.061 & 256.2 \\
0.055 & 251.8 \\
0.047 & 254.3 \\
0.044 & 257.8 \\
0.043 & 258.3 \\
0.042 & 258.6 \\
0.041 & 260.9 \\
0.034 & 264.9 \\
0.030 & 264.2 \\
0.027 & 262.3 \\
0.027 & 263.2 \\
0.028 & 266.7 \\
0.028 & 267.8 \\
0.033 & 277.8 \\
0.034 & 281.7 \\
0.039 & 290.8 \\
0.039 & 289.6 \\
0.038 & 286.8 \\
0.038 & 282.1 \\
0.038 & 279.3 \\
0.039 & 280.2 \\
0.044 & 295.1 \\
0.053 & 307.9 \\
0.059 & 308.9 \\
0.061 & 308.7 \\
0.060 & 306.3 \\
0.061 & 304.6 \\
0.062 & 304.7 \\
0.065 & 304.9 \\
0.067 & 305.4 \\
0.068 & 307.0 \\
0.096 & 303.7 \\
0.102 & 304.5 \\
0.089 & 317.3 \\
&
\end{tabular}

\begin{tabular}{lll}
\multicolumn{2}{c}{ Wi nd } & Norm \\
m/s & dir & Wind \\
4.427 & 209.1 & 3.95 \\
3.674 & 215.1 & 3.08 \\
3.024 & 228.5 & 2.05 \\
2.901 & 237.0 & 1.62 \\
2.726 & 242.7 & 1.27 \\
2.656 & 246.9 & 1.05 \\
2.695 & 247.7 & 1.02 \\
2.757 & 249.0 & 0.97 \\
2.682 & 253.8 & 0.70 \\
2.488 & 261.7 & 0.27 \\
2.435 & 268.6 & 0.08 \\
2.507 & 269.2 & 0.13 \\
2.512 & 269.3 & 0.35 \\
2.496 & 269.7 & 0.80 \\
2.514 & 270.4 & 0.21 \\
2.390 & 274.0 & 0.55 \\
2.292 & 276.1 & 1.26 \\
2.181 & 277.5 & 1.48 \\
2.182 & 277.8 & 0.52 \\
2.210 & 278.5 & 0.56 \\
2.219 & 278.7 & 0.58 \\
2.441 & 277.8 & 2.10 \\
2.465 & 278.7 & 0.64 \\
2.663 & 278.5 & 2.30 \\
2.631 & 280.9 & 0.80 \\
2.576 & 282.3 & 0.85 \\
2.501 & 284.6 & 0.93 \\
2.466 & 286.0 & 0.97 \\
2.429 & 288.3 & 1.05 \\
2.484 & 289.7 & 1.13 \\
2.659 & 289.7 & 1.21 \\
2.640 & 291.3 & 1.22 \\
2.759 & 292.8 & 1.27 \\
2.886 & 293.5 & 1.30 \\
2.955 & 292.5 & 1.26 \\
2.989 & 292.0 & 2.18 \\
3.051 & 290.8 & 2.17 \\
3.081 & 290.2 & 2.84 \\
3.035 & 288.8 & 0.48 \\
3.322 & 280.1 & 1.79 \\
3.360 & 276.3 & 1.59 \\
3.235 & 274.8 & 0.22 \\
& &
\end{tabular}

Position

lot Ion

$27.921-17.526$

$27.916-19.969$

$27.933-23.222$

$27.917-25.408$

$27.889-27.211$

$27.859-29.009$

$27.827-30.118$

$27.794-31.601$

$27.748-33.721$

$27.663-36.417$

$27.525-39.366$

$27.444-40.724$

$27.462-40.942$

$27.511-41.152$

$27.462-41.874$

$27.879-43.422$

$28.276-43.994$

$28.565-44.280$

$28.540-44.572$

$28.471-45.367$

$28.451-45.618$

$27.836-46.206$

$27.779-46.828$

$27.082-47.499$

$26.972-48.787$

$26.913-49.552$

$26.791-50.837$

$26.724-51.600$

$26.590-52.936$

$26.378-54.998$

$26.129-57.473$

$25.815-60.775$

$25.610-63.771$

$25.526-65.888$

$25.489-67.102$

$25.416-67.366$

$25.233-67.978$

$25.075-68.173$

$25.223-68.999$

$24.183-71.863$

$23.737-73.186$

$23.766-74.359$

Notes: Magnetic field measurements are in degrees; westward deflections are negative. All positions are in degrees, north and east being positive from the equator and Greenwich Meridian respectively.

Normal winds are in moters/sec.

All dates are as recorded in Columbus's log, Julian calendar. 
Case 01e: Course: Columbus log from Marden

Positioning: rhumbline

Computation interval: 30 minutes

Day lengthening: used

Mognetic correction: not used

Current field: not used

Wind field: not used Leeway wind factor:

Starting latitude/Longitude position: $28.005 \mathrm{~N} 16.992 \mathrm{~W}$

Starting Day/time: 080300

\begin{tabular}{|c|c|c|c|c|c|c|c|}
\hline & & & & urse & & Dista & ince \\
\hline on & Da & Time & Mag & Var & True & League & $\mathrm{km}$ \\
\hline & & & & 0.0 & & 9.00 & 46.99 \\
\hline & 10 & 0600 & 270.0 & 0.0 & 270.0 & 45.00 & 234.94 \\
\hline & 11 & 0600 & 270.0 & 0.0 & 270.0 & 60.00 & 313.25 \\
\hline & 12 & 0600 & 270.0 & 0.0 & 270.0 & 40.00 & 208.83 \\
\hline & 13 & 0600 & 270.0 & 0.0 & 270 & 33.00 & 172.29 \\
\hline & 14 & 0600 & 270.0 & 0.0 & 270 & 33.00 & 172.29 \\
\hline ep & 15 & 0600 & 270.0 & 0.0 & 270.0 & 20.00 & 104.42 \\
\hline & 16 & 0600 & 270.0 & 0.0 & 270.0 & & 140.96 \\
\hline & 17 & 0600 & & 0.0 & $\begin{array}{l}270 \\
270\end{array}$ & 00 & .61 \\
\hline & $\begin{array}{l}18 \\
19\end{array}$ & $\begin{array}{l}0600 \\
0600\end{array}$ & $\begin{array}{l}270.0 \\
270.0\end{array}$ & $\begin{array}{l}0.0 \\
0.0\end{array}$ & $\begin{array}{l}278.0 \\
270.0\end{array}$ & 55.00 & $\begin{array}{l}281.64 \\
287.14\end{array}$ \\
\hline & 20 & 0600 & 270.0 & 0.0 & 270.0 & 25.00 & 130.52 \\
\hline & 20 & 1800 & 281.2 & 0.0 & 281.2 & 3.80 & 19.84 \\
\hline & 21 & 0600 & 292.5 & 0.0 & 292.5 & 3.80 & 19.84 \\
\hline & 22 & 0600 & 270.0 & 0.0 & 270.0 & 13.00 & \\
\hline & $\begin{array}{l}23 \\
23\end{array}$ & $\begin{array}{l}0600 \\
1800\end{array}$ & $\begin{array}{l}292.5 \\
315.0\end{array}$ & $\begin{array}{l}0.0 \\
0.0\end{array}$ & $\begin{array}{l}292.5 \\
315.0\end{array}$ & $\begin{array}{l}30.60 \\
13.50\end{array}$ & $\begin{array}{r}156.62 \\
70.48\end{array}$ \\
\hline & 24 & 0100 & 326.2 & 0.0 & 326.2 & 8.10 & 42.29 \\
\hline & 24 & 0600 & 270.0 & & 270.0 & 5.40 & 28.19 \\
\hline & 25 & 0600 & 270.0 & 0.0 & 270.0 & 14.50 & 75.70 \\
\hline & 25 & 1800 & 270.0 & 0.0 & 270.0 & 4.50 & 23.49 \\
\hline & $\begin{array}{l}26 \\
26\end{array}$ & $\begin{array}{l}0600 \\
1500\end{array}$ & $\begin{array}{l}225.0 \\
270.0\end{array}$ & $\begin{array}{l}0.0 \\
0.0\end{array}$ & $\begin{array}{l}225.0 \\
270.0\end{array}$ & $\begin{array}{l}17.00 \\
11.60\end{array}$ & $\begin{array}{l}88.75 \\
69.56\end{array}$ \\
\hline & 27 & 0600 & 225.0 & 0.0 & 225.0 & 19.40 & 101.28 \\
\hline & 28 & 0600 & 270.0 & 0.0 & 270.0 & 24.00 & 125.30 \\
\hline & 29 & 0600 & 270.0 & 0.0 & 270.0 & 14.00 & 73.09 \\
\hline & 30 & 0600 & 270.0 & & 270.0 & 80 & 125.30 \\
\hline & $9 ?$ & 0600 & $\begin{array}{l}270.0 \\
270.0\end{array}$ & & $\begin{array}{l}270.0 \\
270.0\end{array}$ & & $\begin{array}{l}.09 \\
52\end{array}$ \\
\hline & $\begin{array}{l}02 \\
03\end{array}$ & $\begin{array}{l}0600 \\
0600\end{array}$ & $\begin{array}{l}270.0 \\
270.0\end{array}$ & & $\begin{array}{l}270.0 \\
270.0\end{array}$ & $\begin{array}{l}25.60 \\
39.00\end{array}$ & $\begin{array}{l}136 \\
203\end{array}$ \\
\hline & 04 & 0600 & 270.0 & & 270.0 & .00 & 245.38 \\
\hline & 05 & 0600 & 270.0 & & 270.0 & & 328 \\
\hline & 06 & 0600 & 270.0 & & 270.0 & & 297 \\
\hline 0 & 07 & 0600 & $\begin{array}{l}270.0 \\
270.0\end{array}$ & & 270.0 & .00 & 208 \\
\hline 0 & 08 & 0600 & $\begin{array}{l}247.5 \\
247.5\end{array}$ & & $\begin{array}{l}240.0 \\
247.5\end{array}$ & $\begin{array}{r}20.60 \\
5.00\end{array}$ & $\begin{array}{r}126.00 \\
26.10\end{array}$ \\
\hline 0 & 09 & 0600 & & 0.0 & 247.5 & 11.80 & \\
\hline 0 & 09 & 1200 & & & 225.0 & & 26.10 \\
\hline & 10 & 0600 & & 0.0 & 281.2 & 15.50 & 80.92 \\
\hline & 11 & $\begin{array}{l}0600 \\
1800\end{array}$ & $\begin{array}{l}247.5 \\
247.5\end{array}$ & 0.0 & $\begin{array}{l}247.5 \\
247.5\end{array}$ & $\begin{array}{l}59.00 \\
27.00\end{array}$ & $\begin{array}{l}308.03 \\
149.96\end{array}$ \\
\hline & 12 & 0200 & 270.0 & & $\begin{array}{l}247.5 \\
270.0\end{array}$ & 22.50 & 117.47 \\
\hline
\end{tabular}

\begin{tabular}{ll}
\multicolumn{2}{c}{ Current } \\
m/s & dir \\
0.000 & 0.0 \\
0.000 & 0.0 \\
0.000 & 0.0 \\
0.000 & 0.0 \\
0.000 & 0.0 \\
0.000 & 0.0 \\
0.000 & 0.0 \\
0.000 & 0.0 \\
0.000 & 0.0 \\
0.000 & 0.0 \\
0.000 & 0.0 \\
0.000 & 0.0 \\
0.000 & 0.0 \\
0.000 & 0.0 \\
0.000 & 0.0 \\
0.000 & 0.0 \\
0.000 & 0.0 \\
0.000 & 0.0 \\
0.000 & 0.0 \\
0.000 & 0.8 \\
0.000 & 0.0 \\
0.000 & 0.0 \\
0.000 & 0.0 \\
0.000 & 0.0 \\
0.000 & 0.0 \\
0.000 & 0.0 \\
0.000 & 0.0 \\
0.000 & 0.0 \\
0.000 & 0.0 \\
0.000 & 0.0 \\
0.000 & 0.0 \\
0.000 & 0.0 \\
0.000 & 0.0 \\
0.000 & 0.0 \\
0.000 & 0.0 \\
0.000 & 0.0 \\
0.000 & 0.0 \\
0.000 & 0.0 \\
0.000 & 0.0 \\
0.000 & 0.0 \\
0.000 & 0.0 \\
0.000 & 0.0 \\
0 & \\
0.00
\end{tabular}

\begin{tabular}{lll}
\multicolumn{2}{c}{ Wind } & Norm \\
m/s & dir & Wind \\
0.000 & 0.0 & 0.00 \\
0.000 & 0.0 & 0.00 \\
0.000 & 0.0 & 0.00 \\
0.000 & 0.0 & 0.00 \\
0.000 & 0.0 & 0.00 \\
0.000 & 0.0 & 0.00 \\
0.000 & 0.0 & 0.00 \\
0.000 & 0.0 & 0.00 \\
0.000 & 0.0 & 0.00 \\
0.000 & 0.0 & 0.00 \\
0.000 & 0.0 & 0.00 \\
0.000 & 0.0 & 0.00 \\
0.000 & 0.0 & 0.00 \\
0.000 & 0.0 & 0.00 \\
0.000 & 0.0 & 0.00 \\
0.000 & 0.0 & 0.00 \\
0.000 & 0.0 & 0.00 \\
0.000 & 0.0 & 0.00 \\
0.000 & 0.0 & 0.00 \\
0.000 & 0.0 & 0.00 \\
0.000 & 0.0 & 0.00 \\
0.000 & 0.0 & 0.00 \\
0.000 & 0.0 & 0.00 \\
0.000 & 0.0 & 0.00 \\
0.000 & 0.0 & 0.00 \\
0.000 & 0.0 & 0.00 \\
0.000 & 0.0 & 0.00 \\
0.000 & 0.0 & 0.00 \\
0.000 & 0.0 & 0.00 \\
0.000 & 0.0 & 0.00 \\
0.000 & 0.0 & 0.00 \\
0.000 & 0.0 & 0.00 \\
0.000 & 0.0 & 0.00 \\
0.000 & 0.0 & 0.00 \\
0.000 & 0.0 & 0.00 \\
0.000 & 0.0 & 0.00 \\
0.000 & 0.0 & 0.00 \\
0.000 & 0.0 & 0.00 \\
0.000 & 0.0 & 0.00 \\
0.000 & 0.0 & 0.00 \\
0.000 & 0.0 & 0.00 \\
0.000 & 0.0 & 0.00 \\
0 & &
\end{tabular}

Position lat lon

$28.005-17.472$

$28.005-19.874$

$28.005-23.076$

$28.005-25.210$

$28.005-26.971$

$28.005-28.732$

$28.005-29.799$

$28.005-31.240$

$28.005-33.322$

$28.005-35.990$

$28.005-38.925$

$28.005-40.259$

$28.040-40.458$

$28.108-40.645$

$28.108-41.340$

$28.649-42.823$

$29.098-43.336$

$29.415-43.579$

$29.415-43.871$

$29.415-44.655$

$29.415-44.899$

$28.849-45.546$

$28.849-46.170$

$28.204-46.905$

$28.204-48.188$

$28.204-48.937$

$28.204-50.220$

$28.204-50.968$

$28.204-52.305$

$28.204-54.390$

$28.204-56.903$

$28.204-60.271$

$28.204-63.319$

$28.204-65.457$

$28.204-66.687$

$28.113-66.934$

$27.901-67.515$

$27.734-67.703$

$27.876-68.513$

$26.813-71.403$

$26.326-72.717$

$26.326-73.900$

Notes: Magnetic field measurements are in degrees; westward deflections are negative. All pósitions are in degrees, north and east being positive from the equator and Greenwich Meridian respectively.

Normal winds are in meters/sec.

All dates are as recorded in Columbus's log, Julian calendar. 
Case 01f: Course: Columbus log from Marden

Positioning: rhumbline

Computation interval: 30 minutes

Day lengthening: used

Magnetic correction: van Bemmelen for 1500 od.

Current field: autumnal

Wind field: outumnal Leeway wind factor: 0.014

Starting latitude/Longitude position: $28.005 \mathrm{~N} \quad 16.992 \mathrm{~W}$

Starting Day/time: 080300

\begin{tabular}{|c|c|c|c|c|c|c|c|}
\hline & & & & ourse & & Disto & ance \\
\hline Aon & Da & & Mag & Var & True & & km \\
\hline$\vec{r}$ & 09 & 0600 & 270.0 & & & & 46.99 \\
\hline ep & 10 & 0600 & 270.0 & & 272.0 & 45.00 & 234.94 \\
\hline ep & 11 & 0600 & 270.0 & & 271.3 & 60.00 & 313.25 \\
\hline ep & 12 & 0600 & 270.0 & & 270.8 & 40.00 & 208.83 \\
\hline ep & 13 & 0600 & 270.0 & & 278 & 33.00 & 172.29 \\
\hline Sep & 14 & 0600 & 270.0 & .1 & 270 & 33.00 & 172.29 \\
\hline iep & 15 & 0600 & 270.0 & -0 & 269.9 & 20.00 & 104.42 \\
\hline$\bullet$ & $\begin{array}{l}16 \\
17\end{array}$ & $\begin{array}{l}0600 \\
0600\end{array}$ & $\begin{array}{l}270.0 \\
270.0\end{array}$ & $\begin{array}{l}-0 \\
-1\end{array}$ & $\begin{array}{l}269.5 \\
268.8\end{array}$ & 27.00 & $\begin{array}{l}140.96 \\
203.61\end{array}$ \\
\hline ep & 18 & 0600 & 270.0 & & 267.8 & 50.00 & 261.04 \\
\hline of & 19 & 0600 & 270.0 & & 266.6 & 55.00 & 287.14 \\
\hline$o p$ & 20 & 0600 & 270.0 & & 266.1 & 25.00 & 130.52 \\
\hline & 20 & 1800 & 281.2 & & 277.2 & 3.80 & 19.84 \\
\hline Sep & 21 & 0600 & 292.5 & & 288.4 & 3.80 & 19.84 \\
\hline Sep & 22 & 0600 & 270.0 & & 265.6 & 13.00 & 67.87 \\
\hline ep & 23 & 0600 & 292.5 & & 287.2 & 30.00 & 156.62 \\
\hline & $\begin{array}{l}23 \\
24\end{array}$ & $\begin{array}{l}1800 \\
0100\end{array}$ & $\begin{array}{l}315.0 \\
326.2\end{array}$ & & 305 & $\begin{array}{l}50 \\
10\end{array}$ & $\begin{array}{l}70.48 \\
42.29\end{array}$ \\
\hline Sep & 24 & 0600 & 270.0 & -6 . & 264.0 & 5.40 & 28.19 \\
\hline & 25 & 0600 & 270.0 & & 263.7 & 14.50 & 75.70 \\
\hline el & 25 & $1800^{\circ}$ & 270.0 & & 263.6 & 4.50 & 23.49 \\
\hline 50 & 26 & 0600 & 225.0 & & 218.6 & 17.00 & 88.75 \\
\hline Se & 26 & 1500 & 270.0 & & & 11.60 & 60.56 \\
\hline Se & 27 & 0600 & 225.0 & & 218.6 & 19.40 & 101.28 \\
\hline Se & 28 & 0600 & 270.0 & -6 & 263.2 & 24.00 & 125.30 \\
\hline Se & 29 & 0600 & 270.0 & $\begin{array}{l}-6 \\
-7\end{array}$ & 263.1 & 4.00 & $\begin{array}{r}73.09 \\
125.39\end{array}$ \\
\hline ct & 01 & 0600 & 270.0 & $\begin{array}{l}-7 \\
-7\end{array}$ & $\begin{array}{l}202.0 \\
262.7\end{array}$ & $\begin{array}{l}24.60 \\
14.00\end{array}$ & $\begin{array}{r}125.30 \\
73.09\end{array}$ \\
\hline & 02 & 0600 & 270.0 & -7 & 262.6 & 25.00 & 130.52 \\
\hline & 03 & 0600 & 270.0 & & 262.6 & 39.00 & 203.61 \\
\hline Or & 04 & 0600 & 270.0 & & 262.7 & & 245.38 \\
\hline & 05 & 0600 & 270.0 & & 263.9 & & 328.91 \\
\hline Oc & 06 & 0600 & 270.0 & & 65.6 & & 297.58 \\
\hline Oc & 07 & 0600 & 270.0 & -3 & 266.8 & 40.00 & 208.83 \\
\hline & $\begin{array}{l}07 \\
98\end{array}$ & 1700 & 270.0 & & 267.5 & 23.00 & 120.08 \\
\hline & 09 & & $\begin{array}{l}247.5 \\
247.5\end{array}$ & $\begin{array}{l}-2 \\
-1\end{array}$ & & & \\
\hline 0 & 09 & 1200 & 225.0 & -1.7 & & .00 & \\
\hline 0 & 10 & 0600 & 281.2 & -1.4 & .8 & 15.50 & \\
\hline & 11 & 0600 & 247.5 & & & 59.00 & 308.03 \\
\hline & $\begin{array}{l}11 \\
12\end{array}$ & $\begin{array}{l}1800 \\
0200\end{array}$ & $\begin{array}{l}247.5 \\
270.0\end{array}$ & & $\begin{array}{l}248.1 \\
270.9\end{array}$ & $\begin{array}{l}27.00 \\
22.50\end{array}$ & $\begin{array}{l}140.96 \\
117.47\end{array}$ \\
\hline & & & & & & & 117.47 \\
\hline
\end{tabular}

Current

$\mathrm{m} / \mathrm{s}$ dir

0.084221 .8

0.089231 .6

0.089243 .1

0.075239 .4

0.065235 .9

0.062241 .7

0.061247 .1

0.063254 .1

0.061256 .1

0.054251 .7

0.047254 .5

0.044258 .1

0.043258 .6

0.042258 .9

0.040261 .3

0.034265 .4

0.030264 .8

0.028262 .7

0.028263 .7

0.028267 .2

0.028268 .3

0.033278 .5

0.034282 .4

0.039291 .1

0.039289 .1

0.038286 .2

0.038281 .6

0.038278 .8

0.039281 .0

0.045296 .2

0.053308 .3

0.060308 .9

0.061308 .5

0.060306 .0

0.061304 .6

0.062304 .7

0.066305 .3

0.068306 .0

0.068304 .8

0.098304 .5

0.097306 .6

0.092321 .1

\begin{tabular}{lll}
\multicolumn{2}{c}{ Wind } & Norm \\
m/s & dir & Wind \\
4.426 & 209.1 & 3.95 \\
3.669 & 215.2 & 3.07 \\
3.021 & 228.7 & 2.05 \\
2.897 & 237.1 & 1.61 \\
2.722 & 242.8 & 1.26 \\
2.657 & 247.0 & 1.04 \\
2.702 & 247.8 & 1.02 \\
2.752 & 249.1 & 0.96 \\
2.676 & 254.0 & 0.69 \\
2.487 & 262.0 & 0.25 \\
2.438 & 268.7 & 0.09 \\
2.515 & 269.2 & 0.14 \\
2.517 & 269.4 & 0.34 \\
2.498 & 269.8 & 0.80 \\
2.517 & 270.5 & 0.21 \\
2.404 & 274.2 & 0.54 \\
2.297 & 276.3 & 1.25 \\
2.183 & 277.6 & 1.48 \\
2.184 & 277.9 & 0.53 \\
2.212 & 278.6 & 0.57 \\
2.221 & 278.8 & 0.58 \\
2.443 & 278.0 & 2.10 \\
2.467 & 278.9 & 0.66 \\
2.665 & 278.8 & 2.31 \\
2.620 & 281.2 & 0.81 \\
2.568 & 282.6 & 0.86 \\
2.491 & 284.9 & 0.94 \\
2.462 & 286.3 & 0.98 \\
2.426 & 288.6 & 1.06 \\
2.501 & 289.7 & 1.14 \\
2.664 & 289.8 & 1.21 \\
2.640 & 291.5 & 1.22 \\
2.774 & 292.9 & 1.27 \\
2.898 & 293.5 & 1.30 \\
2.967 & 292.2 & 1.24 \\
2.999 & 291.6 & 2.17 \\
3.048 & 290.4 & 2.15 \\
3.079 & 289.8 & 2.82 \\
3.034 & 288.3 & 0.45 \\
3.314 & 279.5 & 1.75 \\
3.334 & 275.9 & 1.56 \\
3.202 & 274.5 & 0.20 \\
& &
\end{tabular}

Position lat lon $27.921-17.528$ $27.915-19.983$ $27,932-23.251$ $27.916-25.447$ $27.889-27.259$ $27.858-29.064$ $27.826-30.179$ $27.793-31.669$ $27.745-33.799$ $27.659-36.507$ $27.519-39.470$ $27.438-40.833$ $27.455-41.052$ $27.504-41.264$ $27.455-41.988$ $27.873-43.543$ $28.271-44.117$ $28.561-44.405$ $28.535-44.698$ $28.466-45.496$ $28.445-45.749$ $27.828-46.338$ $27.771-46.963$ $27.072-47.635$ $26.961-48.929$ $26.900-49.697$ $26.778-50.988$ $26.710-51.755$ 26.575 -53.096 $26.363-55.168$ $26.114-57.654$ $25.802-60.972$ $25.601-63.982$ $25.520-66.110$ $25.485-67.329$ $25.412-67.595$ $25.231-68.210$ $25.072-68.406$ $25.222-69.236$ $24.183-72.115$ $23.737-73.444$ $23.768-74.620$

Notes: Magnetic field measurements ore in degrees; westward deflections are negative. Ali positions are in degrees, north and east boing positive from the equator and Greenwich Meridian respectively.

Normal winds are in meters/sec.

All dates ore as recorded in Columbus's log, Julian calendar. 
Case 01g: Course: Columbus log from Morden

Positioning: rhumbline

Computation interval: 30 minutes

Day lengthening: not used

Magnetic correction: van Bemmelen for 1500 od.

Current field: monthly

Wind field: not used Leeway wind factor: 0.014

Starting latitude/Longitude position: $28.005 \mathrm{~N} \quad 16.992 \mathrm{~W}$

Starting Day/time: 080300

\begin{tabular}{|c|c|c|c|c|c|}
\hline & & & & ourse & \\
\hline Ion & & Time & Mag & & True \\
\hline & 09 & 0600 & 270.0 & & 272.4 \\
\hline ep & 10 & 0600 & 270.0 & & 272 \\
\hline$e p$ & 11 & 0600 & 270.0 & & 271.3 \\
\hline ep & 12 & 0600 & 270.0 & & 270.8 \\
\hline ep & 13 & 0600 & 270.0 & & 270.5 \\
\hline & 15 & 0600 & 270.0 & & 269.9 \\
\hline & 16 & 0600 & 270.0 & -0.5 & 269.5 \\
\hline & 17 & 0600 & 270.0 & & 268.8 \\
\hline & 18 & 0600 & 270.0 & & 267.8 \\
\hline & 19 & 0600 & 270.0 & & 266.6 \\
\hline$P$ & 20 & 0600 & 270.0 & & 266.0 \\
\hline ef & 20 & 1800 & 281.2 & & 277.1 \\
\hline$O P$ & 21 & 0600 & 292.5 & & 288.3 \\
\hline & 22 & $\begin{array}{l}0600 \\
0600\end{array}$ & $\begin{array}{l}270.0 \\
292.5\end{array}$ & $\bar{z}$ & $\begin{array}{l}265.5 \\
287.2\end{array}$ \\
\hline$e p$ & 23 & 1800 & 315.0 & -5.7 & 309.3 \\
\hline & 24 & 0100 & 326.2 & -5.9 & 320.3 \\
\hline$p$ & 24 & 0600 & 270.0 & & 263.9 \\
\hline & 25 & 0600 & 270.0 & & 263.6 \\
\hline 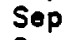 & 25 & 1800 & 270.0 & & 263.5 \\
\hline 0 & 26 & 0600 & 225.0 & & 218.6 \\
\hline ie & 26 & 1500 & 270.0 & & 263.4 \\
\hline & 27 & 0600 & 225.0 & -6 & 218.5 \\
\hline & $\begin{array}{l}28 \\
29\end{array}$ & $\begin{array}{l}0600 \\
0600\end{array}$ & $\begin{array}{l}270.0 \\
270.0\end{array}$ & $\begin{array}{l}-6 \\
-7\end{array}$ & $\begin{array}{l}263.2 \\
263.0\end{array}$ \\
\hline ep & 30 & 0600 & 270.0 & -7.3 & 262.7 \\
\hline & 01 & 0600 & 270.0 & & 262.6 \\
\hline & 02 & 0600 & 270.0 & -7.4 & 262.6 \\
\hline Jc & 03 & 0600 & 270.0 & & 262.6 \\
\hline . & 04 & 0600 & 270.0 & & 262.6 \\
\hline$=t$ & 05 & 0600 & 270.0 & & 263.8 \\
\hline & 06 & 0600 & 270.0 & -4.5 & 265.5 \\
\hline & $\begin{array}{l}07 \\
97\end{array}$ & $\begin{array}{l}0600 \\
1700\end{array}$ & 270.0 & & $\begin{array}{l}266.7 \\
267.4\end{array}$ \\
\hline & 08 & 0600 & 247.5 & & \\
\hline & 09 & 0600 & 247.5 & -2.0 & \\
\hline & 09 & 1200 & 225.0 & & \\
\hline & 10 & 0600 & 281.2 & & \\
\hline & 11 & 0600 & 7.5 & & .6 \\
\hline & 11 & 18 & .5 & & \\
\hline & 12 & & 250.0 & 0.9 & \\
\hline
\end{tabular}

\begin{tabular}{rr}
\multicolumn{2}{c}{ Distance } \\
League & \multicolumn{1}{c}{ km } \\
9.00 & 46.99 \\
45.00 & 234.94 \\
60.00 & 313.25 \\
40.00 & 208.83 \\
33.00 & 172.29 \\
33.00 & 172.29 \\
20.00 & 104.42 \\
27.00 & 140.96 \\
39.00 & 203.61 \\
50.00 & 261.04 \\
55.00 & 287.14 \\
25.00 & 130.52 \\
3.80 & 19.84 \\
3.80 & 19.84 \\
13.00 & 67.87 \\
30.00 & 156.62 \\
13.50 & 70.48 \\
8.10 & 42.29 \\
5.40 & 28.19 \\
14.50 & 75.70 \\
4.50 & 23.49 \\
17.00 & 88.75 \\
11.60 & 60.56 \\
19.40 & 101.28 \\
24.00 & 125.30 \\
14.00 & 73.09 \\
24.00 & 125.30 \\
14.00 & 73.09 \\
25.00 & 130.52 \\
39.00 & 203.61 \\
47.00 & 245.38 \\
63.00 & 328.91 \\
57.00 & 297.58 \\
40.00 & 208.83 \\
23.00 & 120.08 \\
5.00 & 26.10 \\
11.80 & 61.61 \\
5.00 & 26.10 \\
15.50 & 80.92 \\
59.00 & 308.03 \\
27.00 & 140.96 \\
22.50 & 117.47
\end{tabular}

\begin{tabular}{ll}
\multicolumn{2}{c}{ Current } \\
m/s & di r \\
0.092 & 223.9 \\
0.096 & 234.9 \\
0.097 & 246.8 \\
0.087 & 239.7 \\
0.080 & 233.8 \\
0.071 & 240.9 \\
0.065 & 249.2 \\
0.062 & 261.7 \\
0.055 & 266.1 \\
0.041 & 257.1 \\
0.029 & 263.2 \\
0.025 & 272.9 \\
0.024 & 273.8 \\
0.023 & 273.5 \\
0.057 & 252.1 \\
0.045 & 258.1 \\
0.038 & 261.6 \\
0.034 & 263.7 \\
0.034 & 264.5 \\
0.034 & 266.7 \\
0.033 & 267.6 \\
0.037 & 270.3 \\
0.036 & 274.1 \\
0.038 & 279.6 \\
0.038 & 282.8 \\
0.039 & 283.6 \\
0.040 & 285.3 \\
0.041 & 286.3 \\
0.042 & 288.7 \\
0.045 & 294.6 \\
0.049 & 302.2 \\
0.057 & 300.4 \\
0.060 & 297.7 \\
0.059 & 295.9 \\
0.059 & 294.5 \\
0.060 & 294.4 \\
0.062 & 294.4 \\
0.064 & 294.7 \\
0.066 & 294.0 \\
0.106 & 286.5 \\
0.093 & 299.3 \\
0.085 & 301.6 \\
&
\end{tabular}

\begin{tabular}{lll}
\multicolumn{2}{c}{ Wind } & Norm \\
m/s & dir & Wind \\
0.000 & 0.0 & 0.00 \\
0.000 & 0.0 & 0.00 \\
0.000 & 0.0 & 0.00 \\
0.000 & 0.0 & 0.00 \\
0.000 & 0.0 & 0.00 \\
0.000 & 0.0 & 0.00 \\
0.000 & 0.0 & 0.00 \\
0.000 & 0.0 & 0.00 \\
0.000 & 0.0 & 0.00 \\
0.000 & 0.0 & 0.00 \\
0.000 & 0.0 & 0.00 \\
0.000 & 0.0 & 0.00 \\
0.000 & 0.0 & 0.00 \\
0.000 & 0.0 & 0.00 \\
0.000 & 0.0 & 0.00 \\
0.000 & 0.0 & 0.00 \\
0.000 & 0.0 & 0.00 \\
0.000 & 0.0 & 0.00 \\
0.000 & 0.0 & 0.00 \\
0.000 & 0.0 & 0.00 \\
0.000 & 0.0 & 0.00 \\
0.000 & 0.0 & 0.00 \\
0.000 & 0.0 & 0.00 \\
0.000 & 0.0 & 0.00 \\
0.000 & 0.0 & 0.00 \\
0.000 & 0.0 & 0.00 \\
0.000 & 0.0 & 0.00 \\
0.000 & 0.0 & 0.00 \\
0.000 & 0.0 & 0.00 \\
0.000 & 0.0 & 0.00 \\
0.000 & 0.0 & 0.00 \\
0.000 & 0.0 & 0.00 \\
0.000 & 0.0 & 0.00 \\
0.000 & 0.0 & 0.00 \\
0.000 & 0.0 & 0.00 \\
0.000 & 0.0 & 0.00 \\
0.000 & 0.0 & 0.00 \\
0.000 & 0.0 & 0.00 \\
0.000 & 0.0 & 0.00 \\
0.000 & 0.0 & 0.00 \\
0.000 & 0.0 & 0.00 \\
0.000 & 0.0 & 0.00 \\
0 & &
\end{tabular}

Position lat ion $27.968-17.530$ $27.998-19.981$ $28.044-23.243$ $28.046-25.440$ $28.027-27.255$ $28.002-29.063$ $27.979-30.179$ $27.960-31.666$ $27.930-33.788$ $27.854-36.482$ $27.720-39.423$ $27.643-40.768$ $27.666-40.978$ $27.723-41.180$ $27.663-41.914$ $28.078-43.474$ $28.477-44.047$ $28.769-44.332$ $28.742-44.626$ $28.666-45.426$ $28.641-45.680$ $28.018-46.260$ $27.956-46.884$ $27.246-47.542$ $27.122-48.831$ $27.049-49.596$ $26.917-50.882$ $26.842-51.647$ $26.700-52.983$ $26.477-55.047$ $26.209-57.521$ $25.875-60.824$ $25.648-63.824$ $25.542-65.945$ $25.495-67.160$ $25.407-67.420$ $25.195-68.024$ $25.029-68.213$ $25.165-69.042$ $24.092-71.907$ $23.631-73.230$ $23.655-74.402$

Notes: Magnetic field meosurements ore in degrees; westward deflections are negative. All positions are in degrees, north and east being positive from the equator and Greenwich Meridian respectively. Normal winds ore in moters/sec.

All dates are as recorded in Columbus's log. Jullan calendar. 
Case 01h: Course: Columbus log from Marden

Positioning: rhumbline

Computation interval: 30 minutes

Day lengthening: not used

Magnetic correction: van Bemmelen for 1500 ad.

Current fiold: monthly

Wind field: monthly Leeway wind factor:

Starting latitude/Longitude position: $28.005 \mathrm{~N} 16.992 W$

Storting Doy/time: 080300

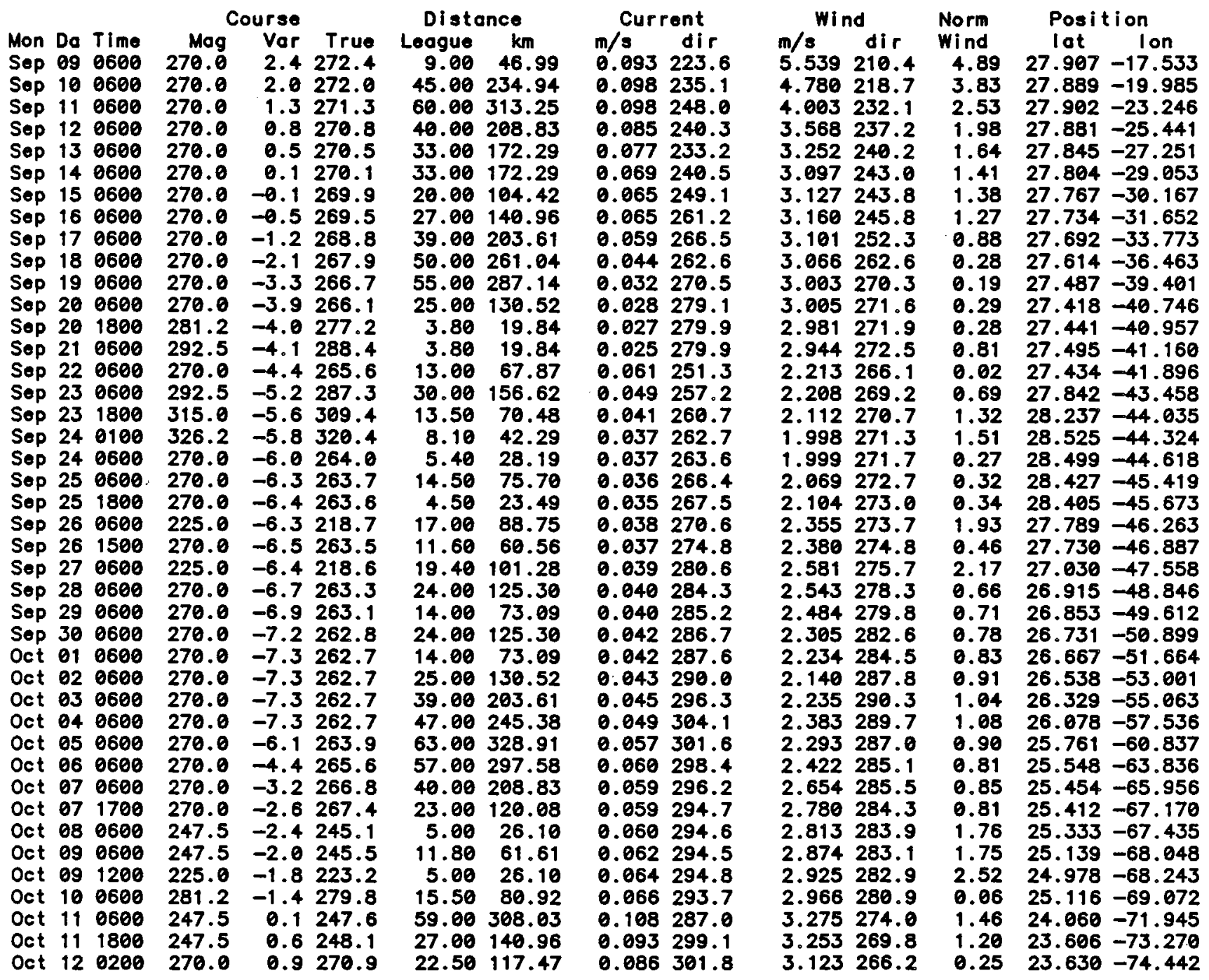

Notes: Magnetic field measurements are in degrees; westward deflections are negative. All positions are in degrees, north and east being positive from the equator and Greenwich Meridian respectively.

Normal winds are in meters/sec.

All dates are as recorded in Columbus's log, Julian colendar. 
Case 02b: Course: Columbus log from Marden

Positioning: rhumbline

Computation interval: 30 minutes

Day lengthening: not used

Magnetic correction: van Bemmelen for 1500 ad.

Curront field: autumnal

Wind field: monthly Leeway wind foctor: 0.014

Starting latitude/Longitude position: $28.005 \mathrm{~N} 16.992 \mathrm{~W}$

Starting Day/time: 080300

\begin{tabular}{|c|c|c|c|c|c|c|c|c|c|c|c|c|c|c|}
\hline & & & & ourse & & Disto & ance & Curr & ent & Win & & Norm & Posit & ion \\
\hline & $\mathrm{Da}$ & & $\mathrm{Mog}$ & Var & True & League & km & $\mathrm{m} / \mathrm{s}$ & dir & $\mathrm{m} / \mathrm{s}$ & di $r$ & Wind & lat & Ion \\
\hline & 09 & & 270.0 & & & 9.00 & 46.99 & 0.084 & & 5.539 & & 4.89 & 27.910 & 526 \\
\hline & 10 & 0600 & 270.0 & & 272.0 & 45.00 & 234.94 & 0.090 & 231. & 4.783 & 218 & 3.8 & 27.895 & 970 \\
\hline & 11 & 0600 & 270.0 & & 271.3 & 60.00 & 313. & 0.090 & 243.3 & & 232.1 & & & .222 \\
\hline & 12 & 0600 & 270.0 & & 270.8 & 40.00 & 208 & 0.076 & & & 237 & 1.98 & & 408 \\
\hline & 13 & 0600 & 270.0 & & & & 172 & 0.065 & & & $24 e$ & & & \\
\hline & & 0600 & 270.0 & & & 33.00 & & 0.062 & & & 243.0 & & & \\
\hline & 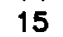 & 0600 & 270.0 & & 269.9 & 20.00 & 104.42 & 0.061 & 246.7 & 3.115 & 243.8 & 1.3 & 27.784 & \\
\hline & 16 & 0600 & 270.0 & & 269.6 & 27.00 & $140.96^{\circ}$ & 0.063 & 253.7 & 3.158 & 245.7 & 1.28 & 27.747 & .598 \\
\hline & 17 & 0600 & 270.0 & -1 & 268.9 & 39.00 & 203.61 & 0.061 & 256.2 & 102 & 252.1 & 0.89 & 398 & .717 \\
\hline & 18 & 0600 & 270.0 & & 267.9 & & 261. & 0.055 & & & 262.4 & 0.29 & 7.612 & 412 \\
\hline & 19 & 0600 & 270.0 & & 266 & & & 0.047 & & .009 & 270.2 & 0.18 & & \\
\hline & 20 & 0600 & 270.0 & & 266 & .00 & 130.52 & 0.044 & & 3.017 & 271.5 & 0.2 & 27.398 & -40.718 \\
\hline & 20 & 1800 & 281.2 & & & .80 & & 0.043 & & .995 & & & & -40.936 \\
\hline & 21 & 0600 & 292.5 & & 288.5 & .80 & & 0.042 & .8 & & 27 & 0.8 & 64 & 147 \\
\hline & 22 & 0600 & 270.0 & -4 & 26 & 13.00 & 37 & 0.041 & 261.1 & 9 & 266.0 & 0.01 & 27.414 & .868 \\
\hline & 23 & 0600 & 292.5 & & 28 & 30.00 & 156 & 0.034 & 265.2 & 209 & 269.1 & 0.69 & & .416 \\
\hline & 23 & 1800 & 315.0 & & & 13.50 & & 0.030 & 264 & 112 & 270.6 & & 28.228 & 188 \\
\hline & 24 & 0100 & 326.2 & & & 3.10 & & 028 & & .001 & 271.3 & 51 & & 4.274 \\
\hline & 24 & 0600 & 270.0 & -5.9 & 264.1 & 5.40 & 28.19 & 0.028 & 263 & 2.002 & 271.6 & 0.2 & 28.491 & .566 \\
\hline & 25 & 0600 & 270.0 & -6 & 263 & 14.50 & 75. & 0.028 & 267.4 & .066 & 272.6 & 0.32 & 28.420 & -45.360 \\
\hline & 25 & 1800 & 270.0 & & & 4.50 & & 0.029 & 268.6 & & 273 & & 28.398 & 112 \\
\hline & 26 & 0600 & 225.0 & & 3.7 & 17.00 & & 0.0 & & & & & & -4 \\
\hline & 26 & 1500 & 270.0 & & .5 & 11.60 & & 0 & & 381 & 274.6 & & & -4 \\
\hline & 27 & 0600 & 225.0 & -6 . & 218.6 & 19.40 & 101.28 & 0.040 & 291.3 & .581 & 275.5 & 6 & 229 & -4 \\
\hline & 28 & 0600 & 270.0 & & 263.3 & & 125 & 0.040 & 289.7 & & 278 & 0.6 & & -48.779 \\
\hline & 29 & 0600 & 270.0 & & & & & & & & & & & \\
\hline & 30 & 0600 & 270.0 & & & & 12 & & & & 2.4 & & & -5 \\
\hline & 01 & 0600 & 270.0 & -7 & 262.8 & 14.00 & 73 & 0.039 & 279.7 & 1 & 284.3 & 0 & & -5 \\
\hline & 02 & 0600 & 270.0 & -7 & 262.7 & 25.00 & 130 & $0 . e$ & 288 & & 287.6 & & & -5 \\
\hline & $0 \overline{3}$ & 0600 & 270.0 & & 262.7 & 39.00 & 203.61 & & & & 290.2 & & & \\
\hline & 04 & 0600 & & & & & & & & & & & & \\
\hline & 05 & 0600 & 270.0 & -6. & 263.8 & 63.00 & 328.91 & 0.060 & 309.2 & 2.301 & & & & -6 \\
\hline & 06 & 0600 & 270 & -4 & 265.5 & 57.00 & 297 & 0.061 & 309.1 & 2.416 & 285.1 & $\theta$ & 25 & -6 \\
\hline & 07 & 0600 & 270.0 & & 266 & 40.00 & 208.83 & 0.061 & 306.4 & & 285.5 & & & -6 \\
\hline & 07 & 1700 & 270.0 & & .4 & 23.00 & 120 & & 304.6 & & .4 & & & -6 \\
\hline & 08 & 0600 & 247.5 & & & 5.00 & & & & & & & & \\
\hline & 09 & & & & & 11.80 & & & & & & & & \\
\hline & 09 & & & & 223.2 & & & & & & & & & \\
\hline & 10 & 2600 & 281.2 & -1 & 9.7 & 15.50 & 80.92 & & & & & & & \\
\hline & 11 & 0600 & & & & 00 & 308 & & & & & & & \\
\hline & 11 & 1800 & & & & & 140 & & & & & & & .165 \\
\hline & & & & & & 22.50 & & & & 3.127 & 6.6 & 0.23 & 23.688 & -74.337 \\
\hline
\end{tabular}

Notes: Magnetic field measurements are in degrees; westward deflections ore negative.

Ali positions are in degrees, north and east being positive from the equator and Greenwich Meridian respectively.

Normal winds are in meters/sec.

All dates are as recorded in Columbus's log, Julian calendar. 
Case 02d: Course: Columbus log from Marden

Positioning: rhumblino

Computation interval: 30 minutes

Day lengthening: not used

Mognetic correction: van Bemmelen for 1500 ad.

Current field: monthly

Wind field: autumnal

Leeway wind factor:

0.014

Starting latitude/Longitude position: $28.005 \mathrm{~N} 16.992 \mathrm{~W}$

Storting Day/time: 080300

\begin{tabular}{|c|c|c|c|c|c|}
\hline & & & & ourse & \\
\hline & Do & & Mog & & True \\
\hline & & 0600 & 270.0 & & 272.4 \\
\hline & 10 & 0600 & 270.0 & & 272.0 \\
\hline ep & 11 & 0600 & 270.0 & & 271.3 \\
\hline ep & 12 & 0600 & 270.0 & & 270.8 \\
\hline Sep & 13 & 0600 & 270.0 & 0.5 & 270.5 \\
\hline Sep & 14 & 0600 & 270.0 & 0.1 & 270.1 \\
\hline Sep & $\begin{array}{l}15 \\
16\end{array}$ & $\begin{array}{l}0600 \\
0600\end{array}$ & $\begin{array}{l}270.0 \\
270.0\end{array}$ & $\begin{array}{l}-0.1 \\
-0.5\end{array}$ & $\begin{array}{l}269.9 \\
269.5\end{array}$ \\
\hline ep & 17 & 0600 & 270.0 & -1.2 & 268.8 \\
\hline ep & 18 & 0600 & 270.0 & -2 & 267.8 \\
\hline $\begin{array}{l}\text { Sep } \\
\text { Sep }\end{array}$ & $\begin{array}{l}19 \\
20\end{array}$ & $\begin{array}{l}0600 \\
0600\end{array}$ & $\begin{array}{l}270.0 \\
270.0\end{array}$ & $\begin{array}{l}-3.4 \\
-3.9\end{array}$ & $\begin{array}{l}266.6 \\
266.1\end{array}$ \\
\hline & 20 & 1800 & 281.2 & -4.0 & 277.2 \\
\hline Sep & 21 & 0600 & 292.5 & & 288.4 \\
\hline $\begin{array}{l}\text { Sep } \\
\text { Sep }\end{array}$ & $\begin{array}{l}22 \\
23\end{array}$ & $\begin{array}{l}0600 \\
9600\end{array}$ & $\begin{array}{l}270.0 \\
292.5\end{array}$ & & $\begin{array}{l}265.6 \\
287.3\end{array}$ \\
\hline & 23 & 1800 & 315.0 & -5 & 309.4 \\
\hline & 24 & 0100 & 326.2 & & 320.3 \\
\hline & $\begin{array}{l}24 \\
25\end{array}$ & $\begin{array}{l}0600 \\
0600\end{array}$ & $\begin{array}{l}270.0 \\
270.0\end{array}$ & $\begin{array}{l}-6 \\
-6\end{array}$ & $\begin{array}{l}264.0 \\
263.7\end{array}$ \\
\hline & 25 & 1800 & 270.0 & & 263.6 \\
\hline & 26 & 0600 & 225.0 & & 218. \\
\hline & $\begin{array}{l}26 \\
27\end{array}$ & $\begin{array}{l}1500 \\
0600\end{array}$ & $\begin{array}{l}270.0 \\
225.0\end{array}$ & & \\
\hline & 28 & 0600 & 270.0 & -6.7 & 263.3 \\
\hline & 29 & 0600 & 270.0 & -6.9 & 263.1 \\
\hline & 30 & 0600 & 270.0 & & $\begin{array}{l}2.8 \\
2.7\end{array}$ \\
\hline & 02 & 0600 & 270.0 & & 262.6 \\
\hline & 03 & 0600 & 270.0 & & 262.6 \\
\hline & 04 & 0600 & 270.0 & & 262.7 \\
\hline & $\begin{array}{l}05 \\
06\end{array}$ & 0600 & $\begin{array}{l}270.0 \\
270.0\end{array}$ & & $\begin{array}{l}3.8 \\
5.6\end{array}$ \\
\hline & 07 & 0600 & 270.0 & -3.3 & 266.8 \\
\hline & 07 & 1700 & 270.0 & -2.6 & 267.4 \\
\hline & 88 & 0600 & $\begin{array}{l}247.5 \\
247.5\end{array}$ & & \\
\hline & $\begin{array}{l}09 \\
09\end{array}$ & $\begin{array}{l}0600 \\
1200\end{array}$ & $\begin{array}{l}247.5 \\
225.0\end{array}$ & $\begin{array}{l}-2.6 \\
-1.8\end{array}$ & $3.2+3$ \\
\hline & 10 & 0600 & 281.2 & 1.4 & \\
\hline & $\begin{array}{l}11 \\
11\end{array}$ & $\begin{array}{l}0600 \\
1800\end{array}$ & $\begin{array}{l}247.5 \\
247.5\end{array}$ & & \\
\hline & 12 & & 270.0 & 0.9 & \\
\hline
\end{tabular}

Distance

League km

$9.00 \quad 46.99$

45.00234 .94

60.00313 .25

40.00208 .83

33.00172 .29

33.00172 .29

20.00104 .42

$27.00 \quad 140.96$

$39.00 \quad 203.61$

50.00261 .04

$55.00 \quad 287.14$

25.00130 .52

$3.80 \quad 19.84$

$3.80 \quad 19.84$

$13.00 \quad 67.87$

$30.00 \quad 156.62$

$13.50 \quad 70.48$

$8.10 \quad 42.29$

$5.40 \quad 28.19$

$14.50 \quad 75.70$

$4.50 \quad 23.49$

$17.00 \quad 88.75$

$11.60 \quad 60.56$

$19.40 \quad 101.28$

$24.00 \quad 125.30$

$14.00 \quad 73.09$

$24.00 \quad 125.30$

$14.00 \quad 73.09$

$25.00 \quad 130.52$

39.00203 .61

$47.00 \quad 245.38$

63.00328 .91

$57.00 \quad 297.58$

40.00208 .83

23.00120 .08

$5.00 \quad 26.10$

$11.80 \quad 61.61$

$5.00 \quad 26.10$

$15.50 \quad 80.92$

59.00308 .03

$27.00 \quad 140.96$

$22.50 \quad 117.47$

\begin{tabular}{lc}
\multicolumn{2}{c}{ Curront } \\
m/s & di r \\
0.092 & 223.7 \\
0.097 & 235.1 \\
0.098 & 247.8 \\
0.086 & 240.2 \\
0.078 & 233.3 \\
0.069 & 240.6 \\
0.065 & 249.1 \\
0.064 & 261.3 \\
0.058 & 266.4 \\
0.043 & 261.6 \\
0.031 & 269.1 \\
0.027 & 277.9 \\
0.026 & 278.8 \\
0.025 & 278.7 \\
0.060 & 251.5 \\
0.048 & 257.3 \\
0.040 & 260.9 \\
0.036 & 262.9 \\
0.036 & 263.8 \\
0.035 & 266.5 \\
0.035 & 267.5 \\
0.038 & 270.6 \\
0.037 & 274.6 \\
0.038 & 280.4 \\
0.039 & 283.9 \\
0.040 & 284.8 \\
0.041 & 286.3 \\
0.042 & 287.2 \\
0.043 & 289.6 \\
0.045 & 295.7 \\
0.049 & 303.3 \\
0.057 & 301.0 \\
0.060 & 298.0 \\
0.059 & 295.9 \\
0.059 & 294.5 \\
0.060 & 294.4 \\
0.062 & 294.3 \\
0.064 & 294.7 \\
0.065 & 293.2 \\
0.105 & 286.6 \\
0.092 & 299.2 \\
0.087 & 303.0 \\
&
\end{tabular}

\begin{tabular}{lll}
\multicolumn{2}{c}{ Wind } & Norm \\
m/s & di r & Wind \\
4.427 & 209.1 & 3.95 \\
3.671 & 215.2 & 3.07 \\
3.023 & 228.6 & 2.05 \\
2.899 & 237.1 & 1.61 \\
2.726 & 242.8 & 1.27 \\
2.663 & 247.0 & 1.05 \\
2.709 & 247.8 & 1.02 \\
2.761 & 249.1 & 0.97 \\
2.681 & 253.9 & 0.69 \\
2.485 & 261.9 & 0.26 \\
2.430 & 268.7 & 0.09 \\
2.506 & 269.3 & 0.14 \\
2.503 & 269.4 & 0.34 \\
2.484 & 269.8 & 0.79 \\
2.506 & 270.4 & 0.21 \\
2.390 & 274.1 & 0.54 \\
2.292 & 276.2 & 1.25 \\
2.178 & 277.5 & 1.48 \\
2.179 & 277.9 & 0.52 \\
2.207 & 278.6 & 0.57 \\
2.216 & 278.8 & 0.58 \\
2.446 & 277.9 & 2.10 \\
2.464 & 278.8 & 0.65 \\
2.662 & 278.7 & 2.31 \\
2.626 & 281.1 & 0.80 \\
2.572 & 282.4 & 0.85 \\
2.496 & 284.7 & 0.93 \\
2.462 & 286.1 & 0.98 \\
2.421 & 288.5 & 1.06 \\
2.485 & 289.8 & 1.13 \\
2.658 & 289.8 & 1.21 \\
2.639 & 291.4 & 1.22 \\
2.765 & 292.9 & 1.27 \\
2.893 & 293.5 & 1.30 \\
2.963 & 292.4 & 1.25 \\
2.997 & 291.8 & 2.18 \\
3.056 & 290.6 & 2.17 \\
3.086 & 290.0 & 2.84 \\
3.045 & 288.6 & 0.47 \\
3.339 & 279.8 & 1.78 \\
3.365 & 276.0 & 1.58 \\
3.237 & 274.5 & 0.21
\end{tabular}

Position lat Ion $27.918-17.533$

$27.910-19.984$

$27.930-23.246$

$27.913-25.441$

$27.880-27.252$

$27.843-29.055$

$27.810-30.169$

$27.780-31.655$

$27.741-33.776$

$27.664-36.467$

$27.535-39.406$

$27.463-40.750$

$27.485-40.961$

$27.539-41.165$

$27.481-41.900$

$27.890-43.462$

$28.284-44.039$

$28.573-44.328$

$28.547-44.622$

$28.478-45.423$

$28.457-45.678$

$27.841-46.268$

$27.783-46.892$

$27.083-47.564$

$26.969-48.852$

$26.907-49.618$

$26.786-50.906$

$26.723-51.671$

$26.595-53.008$

$26.386-55.072$

$26.134-57.547$

$25.816-60.849$

$25.605-63.850$

$25.515-65.971$

$25.475-67.186$

$25.398-67.453$

$25.208-68.067$

$25.047-68.263$

$25.188-69.091$

$24.135-71.966$

$23.682-73.292$

$23.708-74.465$

Notes: Magnetic field measurements are in degrees; westward deflections are negative. All positions are in degrees, north and east being positive from the equator and Greenwich Meridian respectively.

Normal winds are in meters/sec.

All dotes are as recorded in Columbus's log. Julian calendar. 
Case 020: Course: Columbus log from Marden

Positioning: rhumbline

Computation interval: 30 minutes

Day lengthening: not used

Magnetic correction: van Bemmelon for 1500 od.

Current field: September

Wind field: September Leeway wind factor: 0.014

Starting latitude/Longitude position: $28.005 \mathrm{~N} 16.992 \mathrm{~W}$

Starting Day/time: 080300

\begin{tabular}{|c|c|c|c|c|c|c|c|}
\hline & & & & ourse & & Dista & ince \\
\hline Mon & $\mathrm{Da}$ & Time & Mog & Vor & True & League & km \\
\hline & 09 & 0600 & 270.0 & & 272.4 & 9.00 & 46.99 \\
\hline & 10 & 0600 & 270.0 & .0 & 272. & 45.00 & 234 \\
\hline Sep & 11 & 0600 & 270.0 & 1.3 & 271.3 & 60.00 & 313.25 \\
\hline$p$ & 12 & 0600 & 270.0 & 0.8 & 270.8 & 40.00 & 208.83 \\
\hline 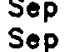 & $\begin{array}{l}13 \\
14\end{array}$ & $\begin{array}{l}0600 \\
0600\end{array}$ & $\begin{array}{l}270.0 \\
270.0\end{array}$ & 0.5 & $\begin{array}{l}270.5 \\
270.1\end{array}$ & 33.00 & $\begin{array}{r}172.29 \\
172.29\end{array}$ \\
\hline & 15 & 0600 & 270.0 & -0. & 269.9 & 20.00 & 104.42 \\
\hline & 16 & 0600 & 270.0 & -0 . & 269.5 & 27.00 & 140.96 \\
\hline & 17 & 0600 & 270.0 & -1. & 268.8 & 39.00 & 203.61 \\
\hline & 18 & $\begin{array}{l}0600 \\
0600\end{array}$ & $\begin{array}{l}270.0 \\
270.0\end{array}$ & $\begin{array}{l}-2 \\
-3\end{array}$ & 267.9 & 50.00 & 261.04 \\
\hline Sep & $\begin{array}{l}19 \\
20\end{array}$ & 0600 & $\begin{array}{l}270.0 \\
270.0\end{array}$ & $\begin{array}{l}-3.3 \\
-3.9\end{array}$ & $\begin{array}{l}266.7 \\
266.1\end{array}$ & $\begin{array}{l}55.00 \\
25.00\end{array}$ & $\begin{array}{l}287.14 \\
130.52\end{array}$ \\
\hline Sep & 20 & 1800 & 281.2 & -4.0 & 277.2 & 3.80 & 19.84 \\
\hline & 21 & 0600 & 292.5 & & 288.4 & 3.80 & 19.84 \\
\hline & $\begin{array}{l}22 \\
23\end{array}$ & $\begin{array}{l}0600 \\
0600\end{array}$ & $\begin{array}{l}270.0 \\
292.5\end{array}$ & $\begin{array}{l}-4.4 \\
-5.2\end{array}$ & $\begin{array}{l}265.6 \\
287.3\end{array}$ & $\begin{array}{l}13.00 \\
30.00\end{array}$ & $\begin{array}{r}67.87 \\
156.62\end{array}$ \\
\hline Sop & 23 & 1800 & 315.0 & -5.6 & 309.4 & 13.50 & 70.48 \\
\hline ep & 24 & 0100 & 326.2 & -5 . & 320.4 & .10 & 42.29 \\
\hline Sep & $\begin{array}{l}24 \\
25\end{array}$ & $\begin{array}{l}0600 \\
0600\end{array}$ & $\begin{array}{l}270.0 \\
270.0\end{array}$ & & $\begin{array}{l}264.0 \\
263.7\end{array}$ & $\begin{array}{r}5.40 \\
14.50\end{array}$ & $\begin{array}{l}28.19 \\
75.70\end{array}$ \\
\hline iep & 25 & 1800 & 270.0 & & 263.6 & 4.50 & 23.49 \\
\hline 0 & 26 & 0600 & 225.0 & & 218.7 & 17.00 & 38.75 \\
\hline P & $\begin{array}{l}26 \\
27\end{array}$ & 1500 & 270.0 & & 263.5 & 11.60 & 60.56 \\
\hline sep & 28 & 0600 & $\begin{array}{l}225.0 \\
270.0\end{array}$ & $\begin{array}{l}-6.4 \\
-6.7\end{array}$ & $\begin{array}{l}218.6 \\
263.3\end{array}$ & & $\begin{array}{l}101.28 \\
125.30\end{array}$ \\
\hline & 29 & 0600 & 270.0 & -6.9 & 263.1 & 14.00 & 73.09 \\
\hline & 30 & 0600 & 270.0 & -7.2 & 262.8 & 24.00 & 125.30 \\
\hline & 01 & 0600 & 270.0 & -7. & 262.7 & 14.00 & $\begin{array}{r}73.09 \\
130.52\end{array}$ \\
\hline & $\begin{array}{l}02 \\
03\end{array}$ & $\begin{array}{l}0600 \\
0600\end{array}$ & $\begin{array}{l}270.0 \\
270.0\end{array}$ & & & $\begin{array}{l}25.00 \\
39.00\end{array}$ & $\begin{array}{l}130.52 \\
203.61\end{array}$ \\
\hline Det & 04 & 0600 & 270.0 & -7.3 & 262.7 & 47.00 & 245.38 \\
\hline & 05 & 0600 & 270.0 & -6 & 263.7 & 63 & 328.91 \\
\hline & 06 & 0600 & 270.0 & & 265.4 & & 297.58 \\
\hline & 07 & 0600 & 270.0 & & & & 208.83 \\
\hline & 07 & 1700 & $\begin{array}{l}270.0 \\
247.5\end{array}$ & & 267.3 & 23.00 & $\begin{array}{r}120.08 \\
26.10\end{array}$ \\
\hline & $\begin{array}{l}08 \\
09\end{array}$ & $\begin{array}{l}0600 \\
0600\end{array}$ & $\begin{array}{l}247.5 \\
247.5\end{array}$ & $\begin{array}{l}-2.5 \\
-2.1\end{array}$ & $\begin{array}{l}245.0 \\
245.4\end{array}$ & $\begin{array}{r}5.00 \\
11.80\end{array}$ & $\begin{array}{l}26.16 \\
61.61\end{array}$ \\
\hline & 09 & 1200 & 225.0 & -1.9 & 23.1 & 5.00 & 26.10 \\
\hline 0 & 10 & 0600 & 281.2 & -1.6 & 279.6 & 15.50 & 80.92 \\
\hline 0 & 11 & 0600 & 247.5 & 0.0 & 247.5 & 59.00 & 308.03 \\
\hline 0 & $\begin{array}{l}11 \\
12\end{array}$ & $\begin{array}{l}1800 \\
0200\end{array}$ & $\begin{array}{l}247.5 \\
270.0\end{array}$ & $\begin{array}{l}0.5 \\
0.8\end{array}$ & $\begin{array}{l}248.0 \\
270.8\end{array}$ & $\begin{array}{l}27.00 \\
22.50\end{array}$ & $\begin{array}{l}140.96 \\
117.47\end{array}$ \\
\hline & 12 & 0206 & $2 / 0.0$ & & 270.0 & & 117.47 \\
\hline
\end{tabular}

\begin{tabular}{cc}
\multicolumn{2}{c}{ Current } \\
m/s & dir \\
0.093 & 223.6 \\
0.098 & 235.1 \\
0.098 & 248.0 \\
0.085 & 240.3 \\
0.077 & 233.2 \\
0.069 & 240.5 \\
0.065 & 249.1 \\
0.065 & 261.2 \\
0.059 & 266.5 \\
0.044 & 262.6 \\
0.032 & 270.5 \\
0.028 & 279.1 \\
0.027 & 279.9 \\
0.025 & 279.9 \\
0.024 & 285.9 \\
0.021 & 283.0 \\
0.019 & 271.7 \\
0.018 & 261.2 \\
0.019 & 262.1 \\
0.020 & 266.8 \\
0.021 & 268.0 \\
0.028 & 287.7 \\
0.031 & 290.1 \\
0.041 & 300.7 \\
0.039 & 295.6 \\
0.037 & 289.4 \\
0.035 & 277.6 \\
0.034 & 270.2 \\
0.036 & 269.0 \\
0.044 & 294.2 \\
0.057 & 311.8 \\
0.062 & 315.8 \\
0.064 & 318.6 \\
0.064 & 315.7 \\
0.064 & 313.8 \\
0.065 & 313.9 \\
0.068 & 314.3 \\
0.071 & 314.7 \\
0.073 & 317.7 \\
0.095 & 321.5 \\
0.112 & 310.2 \\
0.103 & 331.2 \\
&
\end{tabular}

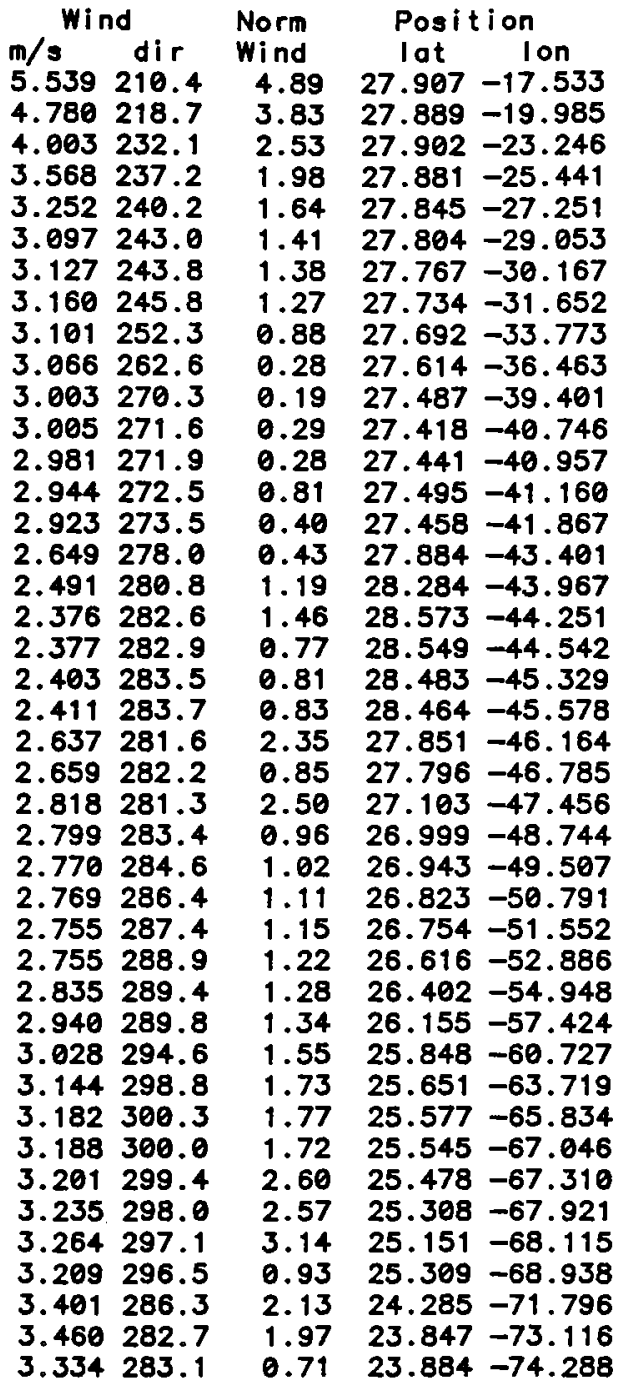

Notes: Magnetic field measurements are in degrees: westward deflections are negative. All positions are in degrees, north and east being positive from the equator and Greenwich Meridian respectively.

Normal winds are in meters/sec.

All dates ore as recorded in Columbus's log. Julian calendar. 
Case 02f: Course: Columbus log from Marden Positioning: rhumbline

Computation interval: 30 minutes

Day lengthening: not used

Magnetic correction: van Bemmelen for 1500 od.

Current field: October

Wind field: October

Leeway wind factor:

0.014

Starting latitude/Longitude position: $28.005 \mathrm{~N} \quad 16.992 \mathrm{~W}$

Starting Day/time: 080300

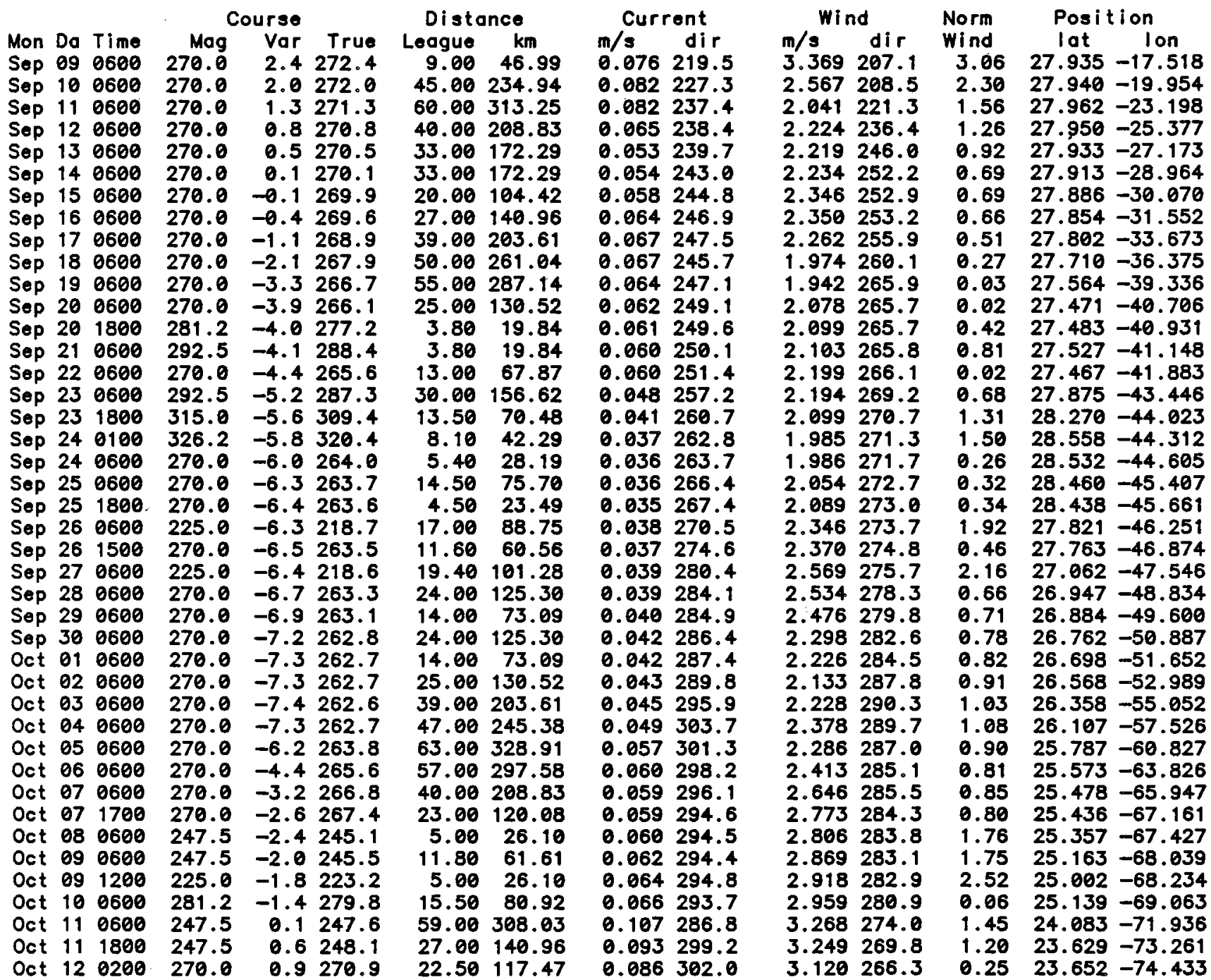

Notes: Magnetic field measurements ore in degrees: westward deflections are negative. All positions are in degrees, north and east being positive from the equator and Greenwich Meridian respectively.

Normal winds are in meters/sec.

All dates ore as recorded in Columbus's log, Julian calendar. 
Case 04b: Course: Columbus log from Morden

Positioning: rhumbline

Computation interval: 30 minutes

Doy lengthening: not used

Magnetic correction: van Bemmelen for 1500 ad.

Current field: autumnal

Wind field: autumnal Leoway wind factor: 0.005

Starting latitude/Longitude position: $28.005 \mathrm{~N} \quad 16.992 W$

Starting Day/time: 080300

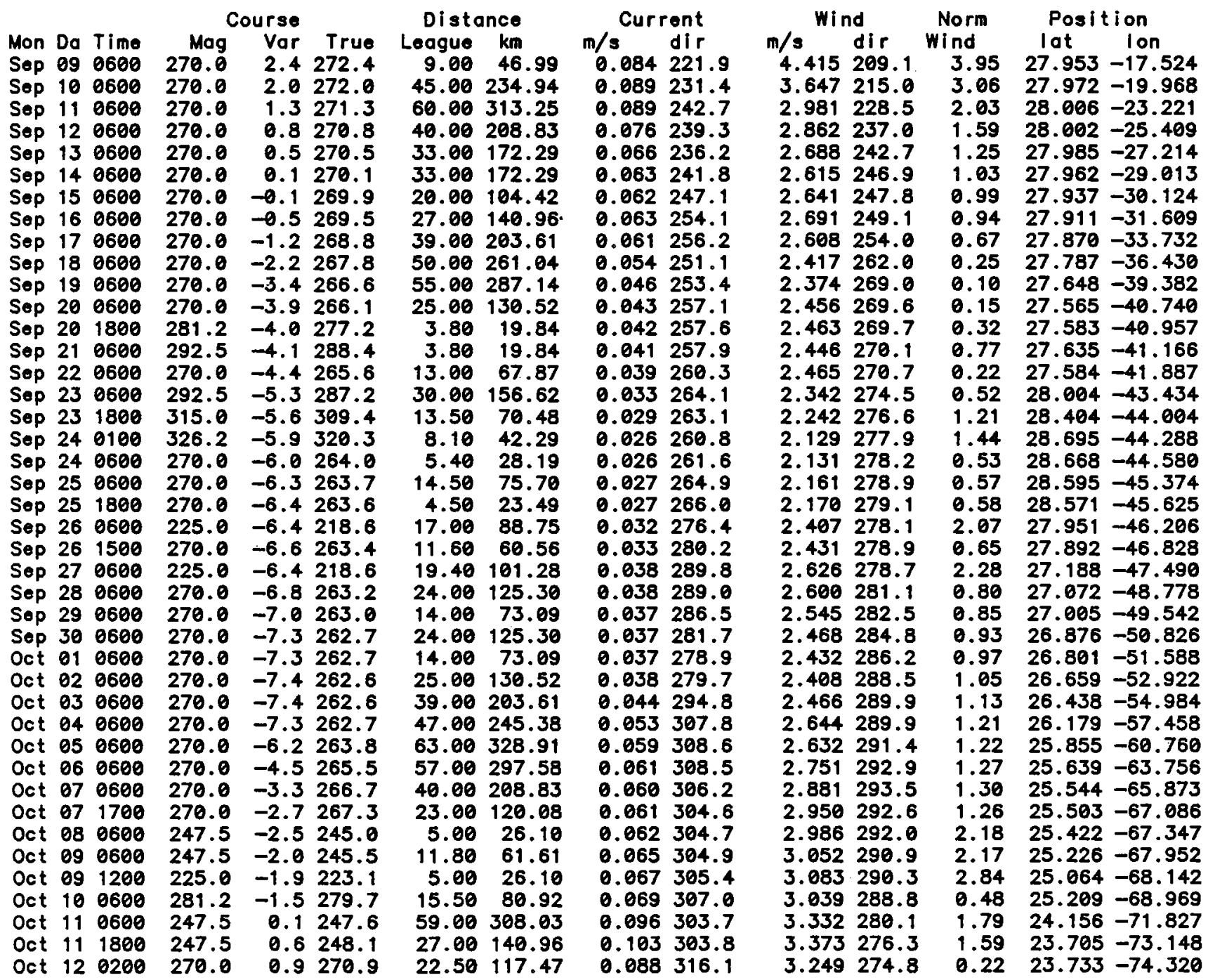

Notes: Magnetic field measurements are in degrees; westward deflections are negative. All positions are in degrees, north and east being positive from the equator and Greenwich Meridian respectively.

Normal winds are in moters/sec.

All dates are as recorded in Columbus's log, Julian calendar. 
Case 04c: Course: Columbus log from Marden

Positioning: rhumbline

Computation interval: 30 minutes

Day lengthening: not used

Magnetic correction: van Bemmelen for 1500 ad.

Current field: outumnal

Wind field: autumanl Leeway wind factor: 0.010

Starting latitude/Longitude position: $28.005 \mathrm{~N} 16.992 \mathrm{~W}$

Starting Day/time: 080300

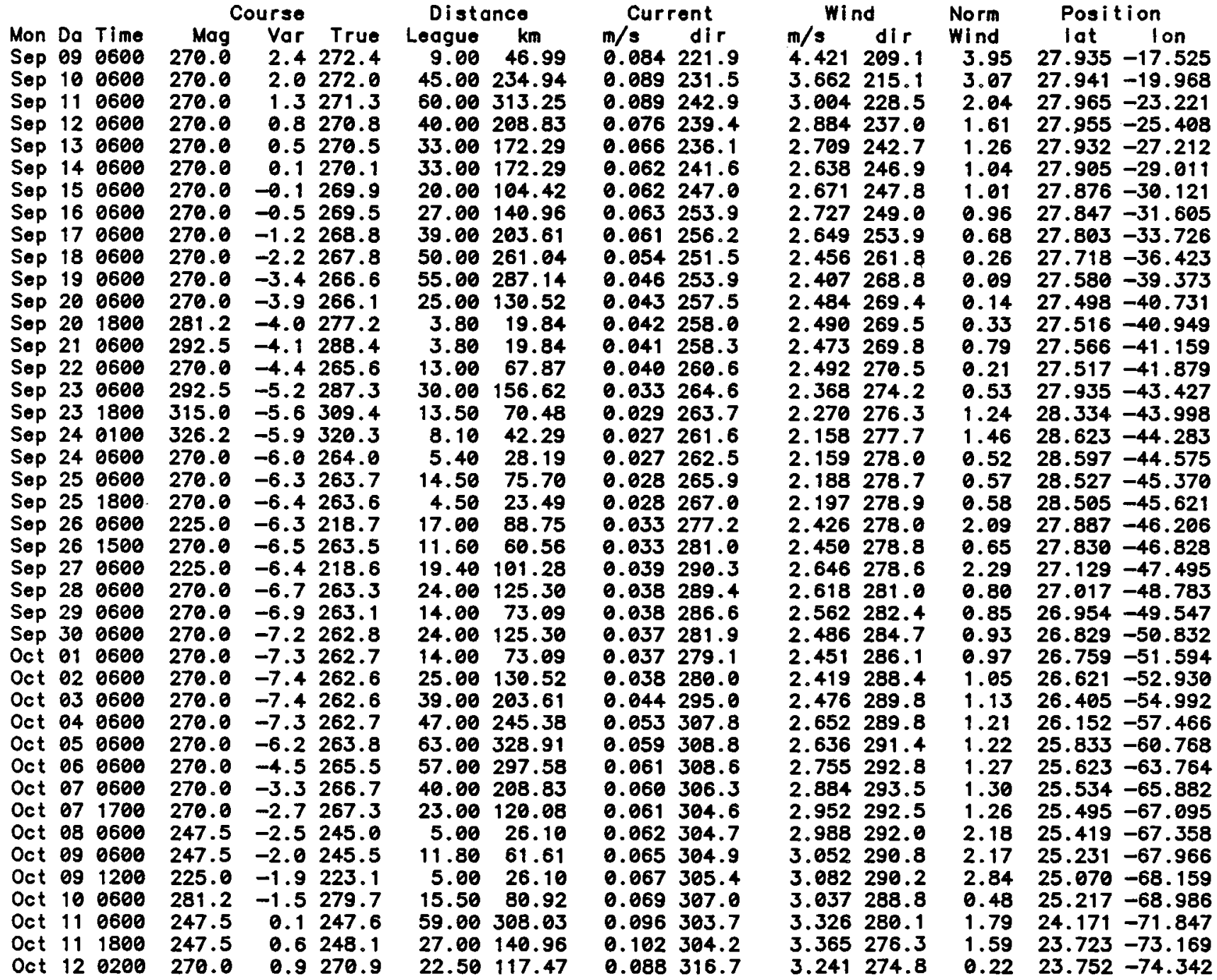

Notes: Magnetic field measurements are in degrees; westward deflections are negative.

All positions are in degrees, north and east being positive from the equator and Greenwich Meridian respectively.

Normal winds are in meters/sec.

All dates are as recorded in Columbus's log, Julian calendar. 
Case 04f: Course: Columbus log from Marden

Positioning: rhumbline

Computation interval: 30 minutes

Day lengthening: not used

Magnetic correction: van Bemmelen for 1500 ad.

Current field: autumnal

Wind field: autumnal Leeway wind factor: 0.020

Starting latitude/Longitude position: $28.005 \mathrm{~N} \quad 16.992 \mathrm{~W}$

Starting Day/time: 080300

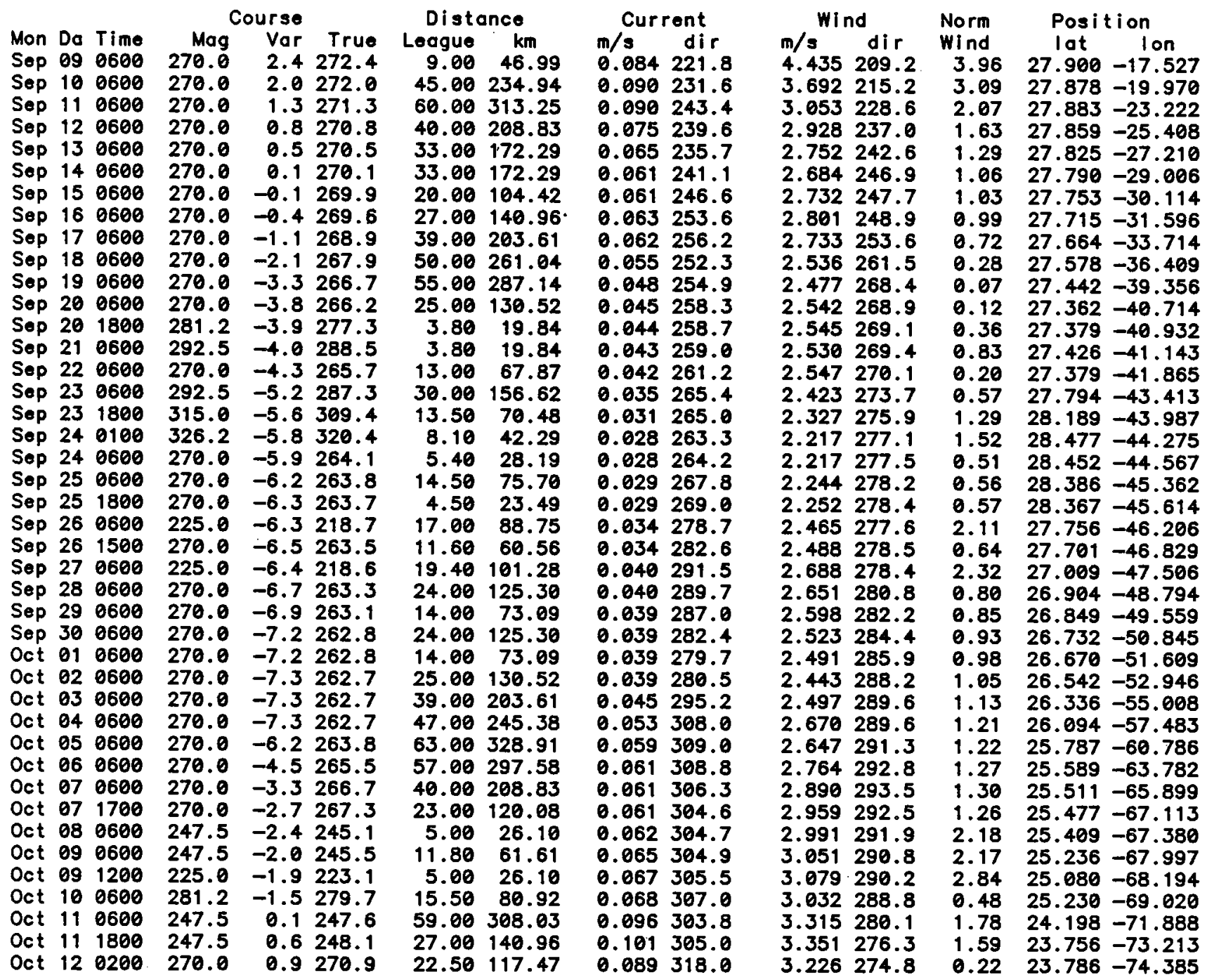

Notes: Magnetic field measurements are in degrees; westward deflections are negative. Ali positions are in degrees, north and east being positive from the equator and Greenwich Meridian respectively.

Normal winds are in meters/sec.

All dates are as recorded in Columbus's log, Julian calendar. 
Case 05d: Course: Columbus log from Marden

Positioning: spherical trigonometry

Computation interval: from log, generally 24 hours

Day lengthening: not used

Magnetic correction: van Bemmelen for 1500 ad.

Current field: outumnal

Leeway wind factor:

0.014

Starting latitude/Longitude position: $28.005 \mathrm{~N} 16.992 \mathrm{~W}$

Starting Day/time: 080300

\begin{tabular}{|c|c|c|c|c|c|}
\hline & & & & ourse & \\
\hline on & $\mathrm{Da}$ & $11 \mathrm{me}$ & Mag & Vor & True \\
\hline & & 0600 & 270.0 & & \\
\hline & 10 & 0600 & 270.0 & & \\
\hline & 11 & 0600 & 270.0 & .0 & 272.0 \\
\hline & 12 & 0600 & 270.0 & & 271.3 \\
\hline & 13 & 0600 & 270.0 & & 270.8 \\
\hline & 14 & 0600 & 270.0 & & 270.5 \\
\hline ep & 15 & 0600 & 270.0 & & 270.1 \\
\hline ep & 16 & 0600 & 270.0 & -0 & 269.9 \\
\hline & 17 & 0600 & 270.0 & -0 & 269.6 \\
\hline & $\begin{array}{l}18 \\
19\end{array}$ & $\begin{array}{l}0600 \\
0600\end{array}$ & $\begin{array}{l}270.0 \\
270.0\end{array}$ & $\begin{array}{l}-1 \\
-2\end{array}$ & $\begin{array}{l}268.9 \\
267.9\end{array}$ \\
\hline & 20 & 0600 & 270.0 & -3.3 & 266.7 \\
\hline & 20 & 1800 & 281.2 & & 277.4 \\
\hline$n_{1}+2-1$ & 21 & 8600 & 292.5 & -3.9 & 288.6 \\
\hline o & 22 & 0600 & 270.0 & & 266.0 \\
\hline ep & 23 & 0600 & 292.5 & & 288.2 \\
\hline Sep & 23 & 1800 & 315.0 & -5.2 & 309.8 \\
\hline Se & 24 & 0100 & 326.2 & -5.6 & 320.6 \\
\hline & $\begin{array}{l}24 \\
25\end{array}$ & $\begin{array}{l}0600 \\
0600\end{array}$ & $\begin{array}{l}270.0 \\
270.0\end{array}$ & $\begin{array}{l}-5.8 \\
-5.9\end{array}$ & $\begin{array}{l}264.2 \\
264.1\end{array}$ \\
\hline ep & 25 & 1800 & 270.0 & -6.2 & $\begin{array}{l}204.1 \\
263.8\end{array}$ \\
\hline$p$ & 26 & 0600 & 225.0 & -6.3 & 218.7 \\
\hline$p$ & 26 & 1500 & 270.0 & -6.2 & 263.8 \\
\hline & 27 & 0600 & 225.0 & -6 & 218.5 \\
\hline 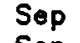 & 28 & 0600 & 270.0 & & 263.7 \\
\hline Sep & $\begin{array}{l}29 \\
30\end{array}$ & 0600 & $\begin{array}{l}270.0 \\
270.0\end{array}$ & $\begin{array}{l}6 \\
8\end{array}$ & $\begin{array}{l}263.4 \\
263.2\end{array}$ \\
\hline Det & 01 & 0600 & 270.0 & & 262.9 \\
\hline Oct & 02 & 0600 & 270.0 & & 262.8 \\
\hline Oct & 03 & 0600 & 270.0 & & 262.8 \\
\hline Oct & 04 & 0600 & 270.0 & & 262.8 \\
\hline Jct & 05 & 0600 & 270.0 & -7 & 262.9 \\
\hline & 06 & 0600 & 270.0 & -6.0 & 264.0 \\
\hline & $\begin{array}{l}07 \\
07\end{array}$ & $\begin{array}{l}0600 \\
1700\end{array}$ & $\begin{array}{l}270.0 \\
270.0\end{array}$ & & 265.8 \\
\hline$c t$ & 08 & 0600 & 247.5 & -2.4 & 245.1 \\
\hline & $\theta 9$ & 0600 & 247.5 & - & 245.2 \\
\hline & 09 & 1200 & 225.0 & -1 & 223.1 \\
\hline & 10 & 0600 & 281.2 & & 279.5 \\
\hline & 11 & 0600 & 247.5 & & 246.1 \\
\hline & 12 & $\begin{array}{l}1800 \\
0200\end{array}$ & $\begin{array}{l}247.5 \\
270.0\end{array}$ & 0.6 & $\begin{array}{l}247.6 \\
270.6\end{array}$ \\
\hline & & 0200 & 210.0 & & \\
\hline
\end{tabular}

Distance

League km

$9.00 \quad 46.99$

45.00234 .94

60.00313 .25

40.00208 .83

$33.00 \quad 172.29$

$33.00 \quad 172.29$

20.00104 .42

$27.00 \quad 140.96$

39.00203 .61

$50.00 \quad 261.04$

55.00287 .14

25.00130 .52

$3.80 \quad 19.84$

$3.80 \quad 19.84$

$13.00 \quad 67.87$

$30.00 \quad 156.62$

$13.50 \quad 70.48$

$8.10 \quad 42.29$

$5.40 \quad 28.19$

$14.50 \quad 75.70$

$4.50 \quad 23.49$

$17.00 \quad 88.75$

$11.60 \quad 60.56$

$19.40 \quad 101.28$

24.00125 .30

$14.00 \quad 73.09$

24.00125 .30

$14.00 \quad 73.09$

$25.00 \quad 130.52$

39.00203 .61

47.00245 .38

63.00328 .91

$57.00 \quad 297.58$

40.00208 .83

$23.00 \quad 120.08$

5.0026 .10

$11.80 \quad 61.61$

$5.00 \quad 26.10$

$15.50 \quad 80.92$

$59.00 \quad 308.03$

$27.00 \quad 140.96$

$22.50 \quad 117.47$
Current

$\begin{array}{ll}0.079 & \text { dir } \\ 0.322 .3\end{array}$

0.084221 .8

0.090231 .8

0.090243 .4

0.075239 .5

0.064235 .7

0.061241 .3

0.061246 .7

0.063253 .7

0.062256 .1

0.055252 .3

0.048255 .3

0.045258 .6

0.044258 .9

0.043259 .2

0.042261 .5

0.035265 .6

0.031265 .1

0.028263 .2

0.028264 .5

0.029268 .1

0.029269 .3

0.034279 .4

0.035283 .2

0.041291 .8

0.041289 .9

0.040287 .3

0.040283 .0

0.040280 .5

0.041281 .3

0.046295 .6

0.055308 .3

0.061310 .7

0.063311 .0

0.063307 .3

0.064304 .8

0.065304 .9

0.067304 .8

0.067304 .8

0.070306 .9

0.116300 .5

0.110297 .8

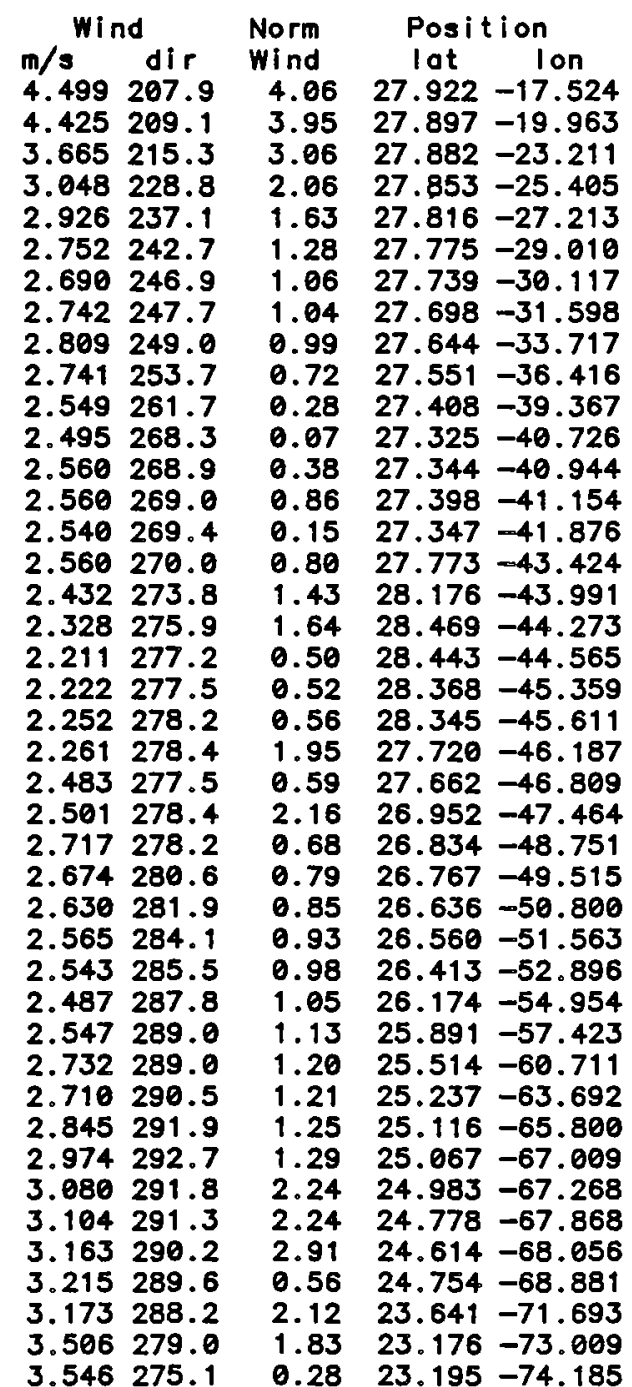

Notes: Magnetic field measurements are in degrees: westward deflections ore negative. All positions are in degrees, north and east being positive from the equator and Greenwich Meridian respectively. Normal winds are in meters/soc.

All dates are as recorded in Columbus's log. Julian calendar. 
Case 05e: Course: Marden casebook [Marden, 1986b]

Positioning: rhumbline

Computation interval: log period

Day lengthening: not used

Mognetic correction: van Bemmelen for 1500 od.

Current field: outumnol

Wind field: autumnal Leeway wind foctor: 0.014

Starting latitude/Longitude position: $28.000 \mathrm{~N} 17.000 \mathrm{~W}$

Starting Day/time: 080300

\begin{tabular}{|c|c|c|c|c|c|c|c|}
\hline \multirow{4}{*}{\multicolumn{2}{|c|}{$\begin{array}{l}\text { Mon } \\
\text { Sep } \\
\text { Sep }\end{array}$}} & \multirow[b]{2}{*}{ Time } & \multicolumn{3}{|c|}{ Course } & \multicolumn{2}{|c|}{ Distance } \\
\hline & & & Mag & Vor & True & eague & Kmeter \\
\hline & & 0600 & 270.0 & & & & 46.99 \\
\hline & & 0600 & 270.0 & 2.4 & 272.4 & 45.00 & 234.94 \\
\hline Sep & 11 & 0600 & 270.0 & 2.0 & 272.0 & 60.00 & 313.25 \\
\hline ep & 12 & 0600 & 270.0 & & 271.3 & 40.00 & 208.83 \\
\hline op & 13 & 0600 & 270.0 & & 270.8 & 33.00 & 172.29 \\
\hline Sep & 14 & 0600 & 270.0 & 0.5 & 270.5 & 33.00 & 172.29 \\
\hline ep & 15 & 0600 & 270.0 & 0.1 & 270.1 & 20.00 & 104.42 \\
\hline & $\begin{array}{l}16 \\
17\end{array}$ & $\begin{array}{l}0600 \\
0609\end{array}$ & 270.0 & -0.1 & 269. & 27.00 & 140.96 \\
\hline & 18 & 0600 & 270.0 & -1.2 & 268.8 & 50.00 & $\begin{array}{l}263.01 \\
261.04\end{array}$ \\
\hline & 19 & 0600 & 270.0 & & 267.8 & 55.00 & 287.14 \\
\hline & 20 & 0600 & 270.0 & -3.4 & 266.6 & 25.00 & 130.52 \\
\hline & 21 & 0600 & 286.9 & -3.9 & 283.0 & 7.50 & 39.16 \\
\hline & 22 & 0600 & 270.0 & & 265.9 & 13.00 & 67.87 \\
\hline & 23 & 0600 & 292.5 & & 288.1 & 30.00 & 156.62 \\
\hline$p$ & 24 & 0600 & 315.0 & -5.3 & 309.7 & 27.00 & 140.96 \\
\hline & 25 & 0600 & 270.0 & & 263.9 & 14.50 & 75.70 \\
\hline & $\begin{array}{l}26 \\
26\end{array}$ & $\begin{array}{l}0600 \\
1800\end{array}$ & $\begin{array}{l}270.0 \\
225.0\end{array}$ & $\begin{array}{l}-6.4 \\
-6.5\end{array}$ & $\begin{array}{l}263.6 \\
218.5\end{array}$ & $\begin{array}{r}4.50 \\
17.00\end{array}$ & $\begin{array}{l}23.49 \\
88.75\end{array}$ \\
\hline & 27 & 0600 & 270.0 & -6.4 & 263.6 & 15.50 & 80.92 \\
\hline & 27 & 1800 & 225.0 & & 218.3 & 15.50 & 80.92 \\
\hline & 28 & 0600 & 270.0 & & 263.4 & 24.00 & 125.30 \\
\hline & 29 & 0600 & 270.0 & & 263.1 & 14.00 & 73.09 \\
\hline & 30 & 0600 & 270.0 & & 262.9 & 24.00 & 125.30 \\
\hline & 01 & 0600 & 270.0 & & 262.6 & 14.00 & 73.09 \\
\hline & 02 & 0600 & 270.0 & & 262.5 & 25.00 & 130.52 \\
\hline & 0 & 0600 & 270.0 & & 262.5 & .00 & $\begin{array}{l}203.61 \\
245.38\end{array}$ \\
\hline & $\begin{array}{l}04 \\
05\end{array}$ & $\begin{array}{l}06000 \\
0600\end{array}$ & & $\begin{array}{l}-7.6 \\
-7.5\end{array}$ & .4 & $\begin{array}{l}47.00 \\
63.00\end{array}$ & .38 \\
\hline & 06 & 0600 & 270.0 & -6.3 & 263.7 & 57.00 & 297.58 \\
\hline & 07 & 0600 & 270.0 & -4.5 & 265.5 & 40.00 & 208.83 \\
\hline & 08 & 0600 & 270.0 & & 266.7 & 28.00 & 146.18 \\
\hline & 09 & 0600 & 247.5 & & 245.0 & 11.80 & 61.61 \\
\hline & 09 & 1200 & 225.0 & & 222.9 & 5.00 & 26.10 \\
\hline & 10 & 0600 & 281.2 & -1 & 279.3 & 15.50 & 80.92 \\
\hline & 11 & 0600 & 247.5 & -1 & 6.0 & 59.00 & 308.03 \\
\hline & 11 & 1800 & 247.5 & & 247.6 & 27.00 & 140.96 \\
\hline & 12 & & 270.0 & & 270.6 & 22.50 & 117.47 \\
\hline
\end{tabular}

\begin{tabular}{ll}
\multicolumn{2}{c}{ Current } \\
m/s & dir \\
0.079 & 222.2 \\
0.084 & 221.8 \\
0.089 & 231.8 \\
0.089 & 243.0 \\
0.075 & 239.3 \\
0.065 & 236.0 \\
0.062 & 241.6 \\
0.061 & 247.0 \\
0.063 & 254.0 \\
0.061 & 256.1 \\
0.054 & 251.5 \\
0.046 & 254.0 \\
0.043 & 257.5 \\
0.041 & 258.2 \\
0.040 & 260.7 \\
0.033 & 264.6 \\
0.026 & 260.7 \\
0.026 & 263.8 \\
0.027 & 264.8 \\
0.032 & 275.8 \\
0.032 & 280.3 \\
0.037 & 288.0 \\
0.036 & 286.9 \\
0.036 & 284.6 \\
0.035 & 280.1 \\
0.034 & 276.8 \\
0.035 & 278.4 \\
0.042 & 295.2 \\
0.052 & 307.7 \\
0.059 & 307.4 \\
0.060 & 307.4 \\
0.059 & 305.7 \\
0.060 & 304.5 \\
0.063 & 304.8 \\
0.065 & 305.4 \\
0.066 & 305.6 \\
0.091 & 303.3 \\
0.099 & 307.9 \\
& \\
0.03 &
\end{tabular}

\begin{tabular}{ll}
\multicolumn{2}{c}{ Wind } \\
$\mathrm{m} / \mathrm{s}$ & dir \\
4.560 & 207.9 \\
4.426 & 209.2 \\
3.654 & 215.3 \\
3.014 & 228.8 \\
2.892 & 237.1 \\
2.718 & 242.8 \\
2.652 & 247.0 \\
2.693 & 247.8 \\
2.748 & 249.0 \\
2.666 & 253.9 \\
2.465 & 262.0 \\
2.406 & 268.8 \\
2.482 & 269.4 \\
2.469 & 269.9 \\
2.489 & 270.6 \\
2.363 & 274.4 \\
2.101 & 278.6 \\
2.129 & 279.2 \\
2.136 & 279.4 \\
2.384 & 278.4 \\
2.406 & 279.5 \\
2.555 & 279.3 \\
2.525 & 281.8 \\
2.471 & 283.2 \\
2.380 & 285.6 \\
2.325 & 287.1 \\
2.334 & 289.5 \\
2.468 & 290.7 \\
2.580 & 290.6 \\
2.585 & 292.1 \\
2.728 & 293.4 \\
2.859 & 293.8 \\
2.933 & 292.2 \\
3.002 & 291.0 \\
3.029 & 290.4 \\
2.964 & 289.0 \\
3.251 & 280.2 \\
3.297 & 276.5
\end{tabular}

Norm Position

Wind lat lon

$4.07 \quad 27.918-17.532$

$3.95 \quad 27.915-19.970$

$3.06 \quad 27.937-23.216$

$2.03 \quad 27.925-25.409$

$1.6127 .900-27.217$

$1.26 \quad 27.871-29.015$

$1.04 \quad 27.839-30.124$

$1.0127 .807-31.605$

$0.9627 .768-33.726$

$0.6927 .701-36.426$

$0.2527 .587-39.381$

$0.0927 .509-40.740$

$0.58 \quad 27.574-41.165$

$0.1727 .526-41.886$

$0.7527 .950-43.435$

$\begin{array}{lll}1.37 & 28.746 & -44.581\end{array}$

$0.5328 .676-45.375$

$0.5728 .657-45.638$

$\begin{array}{llll}1.87 & 28.038 & -46.223\end{array}$

$0.6127 .962-47.055$

$2.11 \quad 27.401-47.588$

$0.70 \quad 27.280-48.862$

$\begin{array}{llll}0.81 & 27.218 & -49.627\end{array}$

$0.8627 .095-50.914$

$0.9327 .024-51.677$

$0.9726 .885-53.012$

$1.0626 .661-55.075$

$1.1426 .397-57.552$

$1.22 \quad 26.050-60.855$

$\begin{array}{lll}1.23 & 25.797 & -63.851\end{array}$

$1.28 \quad 25.690-65.969$

$\begin{array}{lll}1.31 & 25.655 & -67.466\end{array}$

$2.1525 .469-68.075$

$2.7925 .309-68.269$

$0.58 \quad 25.453-69.097$

$2.02 \quad 24.376-71.939$

$\begin{array}{lll}1.75 & 23.922 & -73.258\end{array}$

$0.3423 .949-74.435$

Notes: Magnetic field measurements are in degrees; westward deflections are negative. All positions are in degrees, north and east being positive from the equator and Greenwich Meridian respectively.

Normal winds are in meters/sec.

All dates are as recorded in Columbus's log, Julian calendar. 
Case 06a: Course: Columbus log from Marden

Positioning: rhumbline

Computation interval: 30 minutes

Doy lengthening: not used

Magnetic correction: field from Columbus 1492 observations

Current field: autumnal

Wind field: outumnal Leeway wind factor: 0.014

Starting latitude/Longitude position: $28.005 \mathrm{~N} 16.992 \mathrm{~W}$

Starting Day/time: 080300

\begin{tabular}{|c|c|c|c|c|c|c|c|c|c|c|c|c|c|c|}
\hline \multirow{3}{*}{$\begin{array}{l}\text { Mon } \\
\text { Sep }\end{array}$} & \multirow[b]{2}{*}{$\mathrm{Da}$} & \multirow{4}{*}{$\begin{array}{l}\text { Time } \\
0600 \\
0699\end{array}$} & \multicolumn{3}{|c|}{ Course } & \multicolumn{2}{|c|}{ Distance } & \multicolumn{2}{|c|}{ Current } & \multicolumn{2}{|c|}{ Wind } & \multirow{3}{*}{$\begin{array}{l}\text { Norm } \\
\text { Wind }\end{array}$} & \multirow{2}{*}{\multicolumn{2}{|c|}{$\begin{array}{l}\text { Posititon } \\
\text { lat lon }\end{array}$}} \\
\hline & & & Mog & Var & True & & Kmeter & $\mathrm{m} / \mathrm{s}$ & dir & $\mathrm{m} / \mathrm{s}$ & & & & \\
\hline & & & 270.0 & 2.9 & 272.9 & & 46.99 & 0.084 & 221.8 & & & & & \\
\hline Sep & 10 & & 270.0 & & 272.4 & 45.00 & 234.94 & 0.089 & 231.5 & 664 & 215.1 & 3.08 & & .969 \\
\hline$e p$ & 11 & 0600 & 270.0 & & 271.4 & 60.00 & 313.25 & 0.089 & 242.9 & 804 & 228.5 & 2.04 & 666 & -23.222 \\
\hline e & 12 & 0600 & 270.0 & & 270.7 & & 208.83 & 0.076 & 239.4 & 886 & & 1.60 & & 0.409 \\
\hline & 13 & 0600 & 270.0 & 0.2 & 270.2 & 33.00 & 172.29 & 0.065 & 236.0 & & 24 & 1.26 & & 293 \\
\hline$e$ & 14 & 0600 & 270.0 & -0.3 & 269.7 & 33.00 & 172.29 & 0.062 & 241.5 & 2.649 & & 1.03 & & 9.011 \\
\hline ep & 15 & 0600 & 270.0 & -1.2 & 268.8 & 20.00 & 104.42 & 0.061 & 246.8 & 2.693 & 247.8 & 0.97 & 27.832 & -30.120 \\
\hline ep & 16 & 0600 & 270.0 & -2.3 & 267.7 & 27.00 & 140.96 & 0.063 & 253.7 & 2.772 & 249.0 & 0.89 & & -31.682 \\
\hline ep & 17 & 0600 & 270.0 & -4 & 266.0 & .00 & 203.61 & 0.062 & 256.1 & 2.742 & 253. & 0.59 & 646 & .718 \\
\hline Sep & 18 & 0600 & 270.0 & -5.6 & 264.4 & 50.00 & 261.04 & 0.056 & 253.1 & 2.619 & 261.2 & 0.15 & .428 & -36.401 \\
\hline Sep & 19 & 0600 & 270.0 & -5.5 & 264.5 & .00 & 287.14 & 0.050 & 256.7 & 2.615 & .7 & 0.14 & 27.165 & -39 \\
\hline & $\begin{array}{l}20 \\
20\end{array}$ & $\begin{array}{l}0600 \\
1809\end{array}$ & 270.0 & & 264.7 & $\begin{array}{r}25.00 \\
3.89\end{array}$ & 130.52 & 0.048 & 259.9 & 2.678 & & 0.16 & & -40.687 \\
\hline sep & 21 & 0600 & 292.5 & -5.3 & $\begin{array}{l}275.9 \\
287.2\end{array}$ & $\begin{array}{l}3.80 \\
3.80\end{array}$ & 19.84 & $\begin{array}{l}0.047 \\
0.046\end{array}$ & $\begin{array}{l}260.3 \\
260.6\end{array}$ & $\begin{array}{l}2.675 \\
2.658\end{array}$ & & $\begin{array}{l}0.36 \\
0.85\end{array}$ & 27.107 & -41.120 \\
\hline se & 22 & 0600 & 270.0 & -5.2 & & 13.00 & 67.87 & 0.045 & 262.6 & & & 0.20 & 27.048 & -41.841 \\
\hline & 23 & 0600 & 292.5 & & & 30.00 & 156.62 & 0.038 & 267.1 & & 272.6 & 0.65 & & -43.390 \\
\hline & 23 & 1800 & 315.0 & & 309.7 & 13.50 & 70.48 & 0.034 & 267.5 & 2.459 & & 1.41 & .853 & -43.961 \\
\hline & 24 & 0100 & 326.2 & & 320 & 8.10 & 42.29 & 0.031 & 266.5 & 2.350 & 276 & 1.66 & .144 & -44.246 \\
\hline sep & 24 & 0600 & 270.0 & -5 & 264.7 & 5.40 & 28.19 & 0.031 & 267.6 & 2.350 & 276.4 & 0.48 & 28.121 & -44.537 \\
\hline Sel & 25 & 0600 & 270.0 & -5.3 & 4.7 & 14.50 & 75.70 & 0.031 & 27 & 2.374 & 277.3 & 0.52 & .064 & -45.333 \\
\hline$e$ & 25 & 1800 & 270.0 & & .6 & 4.50 & 23.49 & 0.032 & 272.9 & 2.380 & 277.5 & & .047 & -4 \\
\hline Sep & 26 & 0600 & 225.0 & & & 17.00 & 88.75 & 0.036 & 281 & 2.559 & 276.8 & 15 & 142 & 184 \\
\hline Sep & 26 & 1500 & 270.0 & & & 11.60 & 60.56 & 0.037 & 285.9 & .580 & 277.8 & & .395 & -4 \\
\hline$\theta 0$ & 27 & 0600 & 225.0 & & 219.5 & 19.40 & 101.28 & 0.044 & 299.9 & .794 & 277.7 & 2.38 & .710 & \\
\hline$e$ & 28 & 0600 & 270.0 & -5 & & 24.00 & 125.30 & 0.044 & 29 & .737 & 28 & 0.74 & .622 & -48.780 \\
\hline 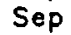 & 29 & 0600 & 270.0 & & 64.4 & 14.00 & 73.09 & 0.043 & 287.8 & 2.695 & 281.5 & 0.79 & .577 & -4 \\
\hline & 30 & 0600 & 270.0 & & & 24.00 & 125 & 0.042 & & & 28 & 0.87 & 485 & -5 \\
\hline 0 & 01 & 0600 & 270.0 & & & 14.00 & 73 & 0.0 & 281.1 & & 285.2 & & .438 & 602 \\
\hline & 02 & 0600 & 270.0 & & 264.4 & 25.00 & 130.52 & 0.042 & 281.7 & & 287.6 & 0.99 & 26.340 & 941 \\
\hline & 03 & 0600 & 270.0 & & 4.5 & 39.00 & 203.6 & 0.046 & 29 & & 28 & 1.06 & 184 & 008 \\
\hline Oc & 04 & 0600 & 270.0 & & 4.8 & 47.00 & 245 & 0.054 & & & 289 & 1.12 & .011 & \\
\hline & 05 & 0600 & $\begin{array}{l}270.0 \\
270.0\end{array}$ & & 266.0 & & $\begin{array}{l}328 \\
29\end{array}$ & $\begin{array}{l}0.059 \\
0.061\end{array}$ & & & & 1.13 & $\begin{array}{l}.810 \\
.703\end{array}$ & \\
\hline & 06 & 0600 & & $\begin{array}{l}-2.3 \\
-1.2\end{array}$ & & & & $\begin{array}{l}0.061 \\
0.059\end{array}$ & & & & 1. & $\begin{array}{l}703 \\
687\end{array}$ & $\begin{array}{l}-6 \\
-6\end{array}$ \\
\hline & 07 & $\begin{array}{l}0600 \\
1700\end{array}$ & $\begin{array}{l}270.0 \\
270.0\end{array}$ & $\begin{array}{l}-1.2 \\
-0.6\end{array}$ & 268.8 & $\begin{array}{l}40.00 \\
23.00\end{array}$ & & $\begin{array}{l}0.059 \\
0.059\end{array}$ & $\begin{array}{l}305.8 \\
304.5\end{array}$ & $\begin{array}{r}.854 \\
890\end{array}$ & $\begin{array}{l}293.8 \\
292.8\end{array}$ & 1. & .688 & -6 \\
\hline $\begin{array}{l}0 \\
0\end{array}$ & $\begin{array}{l}07 \\
08\end{array}$ & $\begin{array}{l}1700 \\
0600\end{array}$ & $\begin{array}{l}270.0 \\
247.5\end{array}$ & $\begin{array}{l}-0.6 \\
-0.5\end{array}$ & $\begin{array}{l}269.4 \\
247.0\end{array}$ & $\begin{array}{r}23.00 \\
5.00\end{array}$ & $\begin{array}{r}120.08 \\
26.10\end{array}$ & $\begin{array}{l}0.059 \\
0.060\end{array}$ & $\begin{array}{l}4.5 \\
4.5\end{array}$ & 2.937 & 292.3 & & 622 & -6 \\
\hline & 09 & 0600 & 247.5 & & 7.2 & 11.80 & & 0.063 & 4.7 & 3.007 & 291.1 & 2.09 & .454 & $-E$ \\
\hline & 09 & 1200 & 225.0 & -0.3 & 1.7 & 5.00 & & 0.065 & 5.2 & 3.030 & 29 & 2.76 & 300 & .231 \\
\hline & 10 & 0600 & 281.2 & -0.1 & 281.1 & 15.50 & 80.9 & 0.066 & 6.0 & 62 & & 0.42 & .464 & \\
\hline & 11 & 0600 & 247.5 & 0.0 & 247.5 & 59.00 & 308.6 & 0.086 & 2.6 & & & 1.75 & .450 & 33 \\
\hline & 11 & 1800 & 247.5 & 0.0 & 247.5 & 27.00 & 140.5 & 0.099 & 308.3 & $=.27$ & & 1.6 & .996 & .253 \\
\hline & 12 & 0200 & 270.0 & 0.0 & 270.0 & 22.50 & 118.78 & 0.092 & 322.2 & 3.159 & & 0.29 & 24.014 & -74.427 \\
\hline
\end{tabular}

Notes: Magnetic field measurements are in degrees; westward deflections are negative. All positions are in degrees, north and east being positive from the equator and Greenwich Meridion respectively.

Normal winds are in meters/sec.

All dates are as recorded in Columbus's log, Julian calendar. 
Case 06b: Course: Columbus log from Morden

Positioning: rhumbline

Computation interval: 30 minutes

Day lengthening: not used

Magnetic correction: Defense Mapping Agency for 1980 ad.

Current field: not used

Wind field: not used Leeway wind factor: 0.014

Starting latitude/Longitude position: $28.005 \mathrm{~N} \quad 16.992 \mathrm{~W}$

Starting Day/time: 080300

\begin{tabular}{|c|c|c|c|c|c|c|c|c|c|c|c|c|c|c|}
\hline \multirow{3}{*}{ Mon } & \multirow{3}{*}{$\begin{array}{l}\mathrm{Da} \\
09\end{array}$} & \multirow{4}{*}{ Time } & \multicolumn{3}{|c|}{ Course } & \multicolumn{2}{|c|}{ Distance } & \multicolumn{2}{|l|}{ Curr } & \multicolumn{2}{|c|}{ Wind } & \multicolumn{3}{|l|}{ Norm } \\
\hline & & & Mag & Var & True & League & $\mathrm{km}$ & $\mathrm{m} / \mathrm{s}$ & dir & $\mathrm{m} / \mathrm{s}$ & alr & & & Ion \\
\hline & & & 270.0 & -10.9 & 259.1 & 9.00 & 46.99 & 0.000 & 0.0 & 0.000 & & 0.00 & 27.926 & -17.461 \\
\hline & 10 & & & & 258.2 & 45.00 & 234.94 & 0.000 & 0.0 & 000 & & 0.00 & 27.510 & 799 \\
\hline & 11 & 0600 & & & 256.9 & & 313.2 & 0.000 & 0.0 & 0.000 & 0. & 0.00 & 01 & 888 \\
\hline & 12 & 0600 & & -1 & 256.2 & & 208.83 & 0.8 & 0.0 & 0.000 & 0.0 & 0.00 & & \\
\hline & 13 & 0600 & & & & 33.00 & 172.29 & 0.000 & 0.0 & 0.000 & 0.0 & 0.00 & & -26.603 \\
\hline & 14 & 0600 & & & 254 & 33.00 & 172.29 & 0.000 & 0.0 & 0.000 & 0.0 & 0.00 & 25.691 & -28.266 \\
\hline & 15 & 0600 & & & 25 & 20.00 & 104.42 & 0.000 & 0.0 & 0.000 & 0.0 & 0.00 & 25.444 & -29.269 \\
\hline & 16 & 0600 & 27 & -1 & 254 & 27.00 & 140.96 & 0.000 & 0.0 & 0.000 & 0.0 & 0.00 & 3.103 & -3 \\
\hline ep & 17 & 0600 & 27 & & 253.6 & 39.00 & 203.61 & 0.000 & 0.0 & 0.000 & 0.0 & 0.00 & 93 & -32 \\
\hline$\theta$ & 18 & 0600 & & & 252.9 & .00 & 261.04 & 0.000 & 0.0 & 0.000 & 0.0 & 0.00 & .918 & -35.017 \\
\hline & 19 & 0600 & & & 25 & .00 & 287.14 & 0.000 & 0.0 & 0.000 & 0.0 & 0.00 & 48 & $\begin{array}{l}-3 \\
-3\end{array}$ \\
\hline & $\begin{array}{l}20 \\
20\end{array}$ & $\begin{array}{l}0600 \\
1800\end{array}$ & & & $\begin{array}{l}252.1 \\
263.3\end{array}$ & $\begin{array}{r}25.80 \\
3.80\end{array}$ & $\begin{array}{r}130.52 \\
19.84\end{array}$ & $\begin{array}{l}0.000 \\
0.000\end{array}$ & $\begin{array}{l}0.0 \\
0.0\end{array}$ & $\begin{array}{l}0.000 \\
0.000\end{array}$ & $\begin{array}{l}0.0 \\
0.0\end{array}$ & $\begin{array}{l}0.00 \\
0.00\end{array}$ & $\begin{array}{l}22.1 \\
22.7\end{array}$ & $\begin{array}{l}-38 \\
-39\end{array}$ \\
\hline & 21 & 0600 & & & & 3.80 & 19.84 & 0.000 & 0.0 & 0.000 & 0.0 & 0.00 & 22 . & 9.299 \\
\hline & 22 & 0600 & & -18.0 & 252.0 & 13.00 & 67.87 & 0.000 & 0.0 & 0.000 & 0.0 & 0.00 & 22.596 & .928 \\
\hline & 23 & 0600 & & -18.1 & 274.4 & 30.00 & 156.62 & 0.000 & 0.0 & 0.000 & 0.0 & 0.00 & 22.704 & .448 \\
\hline & 23 & 1800 & 315.0 & -18.2 & 296.8 & 13.50 & 70.48 & 0.000 & 0.0 & .000 & 0.0 & 0.00 & 22.990 & -42 \\
\hline & 24 & 0100 & 326 & -18.2 & 308.0 & 8.10 & 42.29 & 0.000 & 0.0 & 0.000 & 0.0 & 0.00 & 23.224 & -42.386 \\
\hline & 24 & 0600 & 270.0 & -18.3 & 251.7 & 5.40 & 28.19 & 0.000 & 0.0 & 0.000 & 0.0 & 0.00 & 23.144 & -42.648 \\
\hline & 25 & 0600 & & -18 & 51.7 & 14.50 & 75.70 & 0.000 & 0.0 & 0.000 & 0.0 & 0.00 & 22.931 & -4 \\
\hline & 25 & 1800 & & -18 & 251 & 4.50 & 23.49 & 0.000 & 0.0 & 0.000 & 0.0 & 0.00 & 22.865 & .567 \\
\hline & 26 & 0600 & 225.0 & -18 & 206.8 & 17.00 & 88.75 & 0.000 & 0.0 & .000 & 0.0 & 0.00 & 22.153 & .955 \\
\hline & 26 & 1500 & 270.0 & -18. & 251.8 & 11.60 & 60.56 & 0.000 & 0.0 & 0.000 & 0.0 & 0.00 & 21.983 & -4 \\
\hline & 27 & 0600 & 225.0 & -18.2 & 206.8 & 19.40 & 101.28 & 0.000 & 0.0 & 0.000 & 0.0 & 0.00 & 71 & -4 \\
\hline & 28 & 06 & & -18 & 251.9 & 24.00 & 125 & 0.000 & 0.0 & 0.000 & 0.0 & 0.00 & & -4 \\
\hline & 29 & 0600 & & -18 & 252.0 & & 73 & 0.000 & 0.0 & 0.000 & 0.0 & 0.00 & $\$ 17$ & -4 \\
\hline & 30 & 0600 & 27 & -17 & 252.2 & & 125.30 & 0.0 & 0.0 & 0.000 & 0.0 & 0.00 & 271 & -4 \\
\hline & 01 & 0600 & & -17.7 & 252.3 & 14.00 & 73.89 & 0.000 & 0.0 & 0.000 & 0.0 & 0.00 & .070 & -4 \\
\hline & 02 & 0600 & 270.0 & -17.5 & & 25.00 & 130.52 & 0.000 & 0.8 & 0.000 & 0.0 & 0.00 & & \\
\hline & 03 & 0600 & 270.0 & -17.1 & 252.9 & 39.00 & 203 & 0.000 & 0.0 & 0.000 & 0.0 & 0.00 & 172 & -5 \\
\hline & 04 & 0600 & 270.0 & & 253.5 & & 245 & & 0.0 & & 0.0 & 00 & & \\
\hline & 05 & 06 & & & 254.8 & & 328 & 0.000 & 0.0 & 0.00 & 0.0 & 0.00 & & \\
\hline & 86 & 0600 & 270.0 & -13 & 256 & $\theta 0$ & 297 & 0.000 & 0.8 & 0.000 & 0.0 & 0.00 & & \\
\hline & 07 & 0600 & 270.0 & -12 & 257.5 & 40.00 & 208. & 0.000 & 0.0 & 0.000 & 0.0 & 0.00 & 34 & -6 \\
\hline & 07 & 1700 & 270.0 & -11 & 258.2 & 23.00 & 120 & 0.000 & 0.0 & 0.0 & 0.0 & 0.00 & 07 & 557 \\
\hline & 98 & 0600 & 247.5 & & 235.9 & 5.00 & 26. & 0.000 & 0.0 & 0.000 & 0.0 & 0.00 & & -6 \\
\hline & 09 & & & & 236.2 & 11.80 & & 0.000 & 0.0 & 0.000 & 0.0 & 0.00 & & - \\
\hline & 89 & 1200 & & -11 & & & 26.1 & 0.000 & 0.0 & 0.000 & 0.0 & 0.00 & 72 & 573 \\
\hline & 10 & 0600 & 281.2 & -10 & 270.5 & 15.50 & 80 & 0.0 & 0.0 & 0.000 & 0.0 & 0.00 & & 28 \\
\hline & 11 & 0600 & 247.5 & .7 & 238.8 & 59.00 & 308.8 & 0.000 & 0.0 & 0.000 & 0.0 & 0.00 & & \\
\hline & 11 & 1800 & 247.5 & -7 & 239.7 & 27.00 & 140.9 & 0.000 & 0.0 & 0.000 & 0.0 & 0.00 & & \\
\hline & 12 & & 270.0 & & 263.0 & 22.50 & 117.47 & 0.000 & 0.0 & 0.000 & 0.0 & 0.00 & 13.518 & -68.751 \\
\hline
\end{tabular}

Notes: Magnetic field measurements are in degrees; westward deflections are negative. All positions are in degrees, north and east being positive from the equator and Greenwich Meridian respectively.

Normal winds ore in meters/sec.

All dates ore as recorded in Columbus's log, Julian calendar. 
DOCUMENT LIBRARY

August 21, 1987

Distribution List for Technical Report Exchange

Attn: Stella Sanchez-Wade

Documents Section

Scripps Institution of Oceanography

Library, Mail Code C-075C

La Jolla, CA 92093

Hancock Library of Biology \&

Oceanography

Alan Hancock Laboratory

University of Southern California

University Park

Los Angeles, CA 90089-0371

Gifts \& Exchanges

Library

Bedford Institute of Oceanography

P.O. Box 1006

Dartmouth, NS, B2Y 4A2, CANADA

Office of the International

Ice Patrol

c/o Coast Guard R \& D Center

Avery Point

Groton, CT 06340

Library

Physical Oceanographic Laboratory

Nova University

8000 N. Ocean Drive

Dania, FL 33304

NOAA/EDIS Miami Library Center

4301 Rickenbacker Causeway

Miami, FL 33149

Library

Skidaway Institute of Oceanography

P.O. Box 13687

Savannah, GA 31416

Institute of Geophysics

University of Hawaii

Library Room 252

2525 Correa Road

Honolulu, HI 96822

Library

Chesapeake Bay Institute

4800 Atwell Road

Shady Side, MD 20876

MIT Libraries

Serial Journal Room 14E-210

Cambridge, MA 02139
Director, Ralph M. Parsons Laboratory

Room 48-311

MIT

Cambridge. MA 02139

Marine Resources Information Center

Building E38-320

MIT

Cambridge, MA 02139

Library

Lamont-Doherty Geological Observatory

Colombia University

Palisades, NY 10964

Library

Serials Department

Oregon State University

Corvallis, OR 97331

Pell Marine Science Library

University of Rhode Island

Narragansett Bay Campus

Narragansett, RI 02882

Working Collection

Texas A\&M University

Dept. of Oceanography

College Station, TX 77843

Library

Virginia Institute of Marine Science

Gloucester Point, VA 23062

Fisheries-Oceanography Library

151 Oceanography Teaching Bldg.

University of Washington

Seattle, WA 98195

Library

R.S.M.A.S.

University of Miami

4600 Rickenbacker Causeway

Miami, FL 33149

Maury Oceanographic Library

Naval Oceanographic Office

Bay St. Louis

NSTL, MS 39522-5001 


\section{REPORT DOCUMENTATION PAGE \\ 4. Title and Subtitle \\ Re-constructing Columbus's First Transatlantic Track and Landfall Using Climatological Winds and Currents}

7. Author(s)

R. A. Goldsmith and P. L. Richardson

9. Porforming Organization Name and Address Woods Hole Oceanographic Institution

Woods Hole, Massachusetts 02543
3. Recipient's Accession No.

5. Report Date

November 1987

6.

8. Performing Orenization Rept. No. W HOI-87-46

10. Project/Task/Work Unit No.

11. Contract(C) or Grant(G) No.

(C)

(G) OCE 85-14885

13. Type of Report \& Period Covered

Technical

National Science Foundation

14.

15. Supplementary Notes

This report should be cited as: Woods Hole Oceanog. Inst. Tech. Rept., WHOI-87-46.

16. Abstract (Limit: 200 words)

An article in the November 1986 National Geographic magazine examined the question of Columbus's first landfall in the Americas. The author, Luis Marden, was the first to quantitatively include the effects of the winds and currents in reconstructing the transoceanic portion of the voyage. There seemed, however, to be two major weaknesses in his analysis. First, the leeway effect on the ship by the wind was ignored for that portion of the voyage west of $40 \mathrm{~W}$, the whole second half of the voyage. Second, currents from pilot charts were used with the corresponding speed determined by the prevailing current. We sought to reanalyze the track using the leeway effect for the whole transatlantic track and using more appropriate average vector velocities of the current. Using climatological winds and currents we found the island of San Salvador (Watling Island) to be the most likely site of the first landfall of Columbus. This paper discusses the effects of wind, current, leeway, and magnetic variation on the determination of the landfall.

17. Document Analysis a. Descriptors

1. Voyage of Christopher Columbus

2. Discovery of San Salvador

3. Historical Currents and Winds

b. Identlfiers/Open-Ended Terms

c. COSATI Field/Group

18. Avallability Statemen:

Approved for publication; distribution unlimited.

\begin{tabular}{|c|c|c|}
\hline $\begin{array}{l}\text { 19. Socurity Class (This Report) } \\
\text { UNCLASSIFIED }\end{array}$ & ; & $\begin{array}{c}\text { 21. No. of Pages } \\
51\end{array}$ \\
\hline 20. Security Cless (Thls Page) & & 22. Price \\
\hline
\end{tabular}

